Supporting Information

\title{
A Neutral Silicon(II) Half-Sandwich Compound
}

Tobias Heitkemper, Julijan Sarcevic \& Christian P. Sindlinger*

Institut für Anorganische Chemie, Tammannstr. 4, 37077 Göttingen, Germany

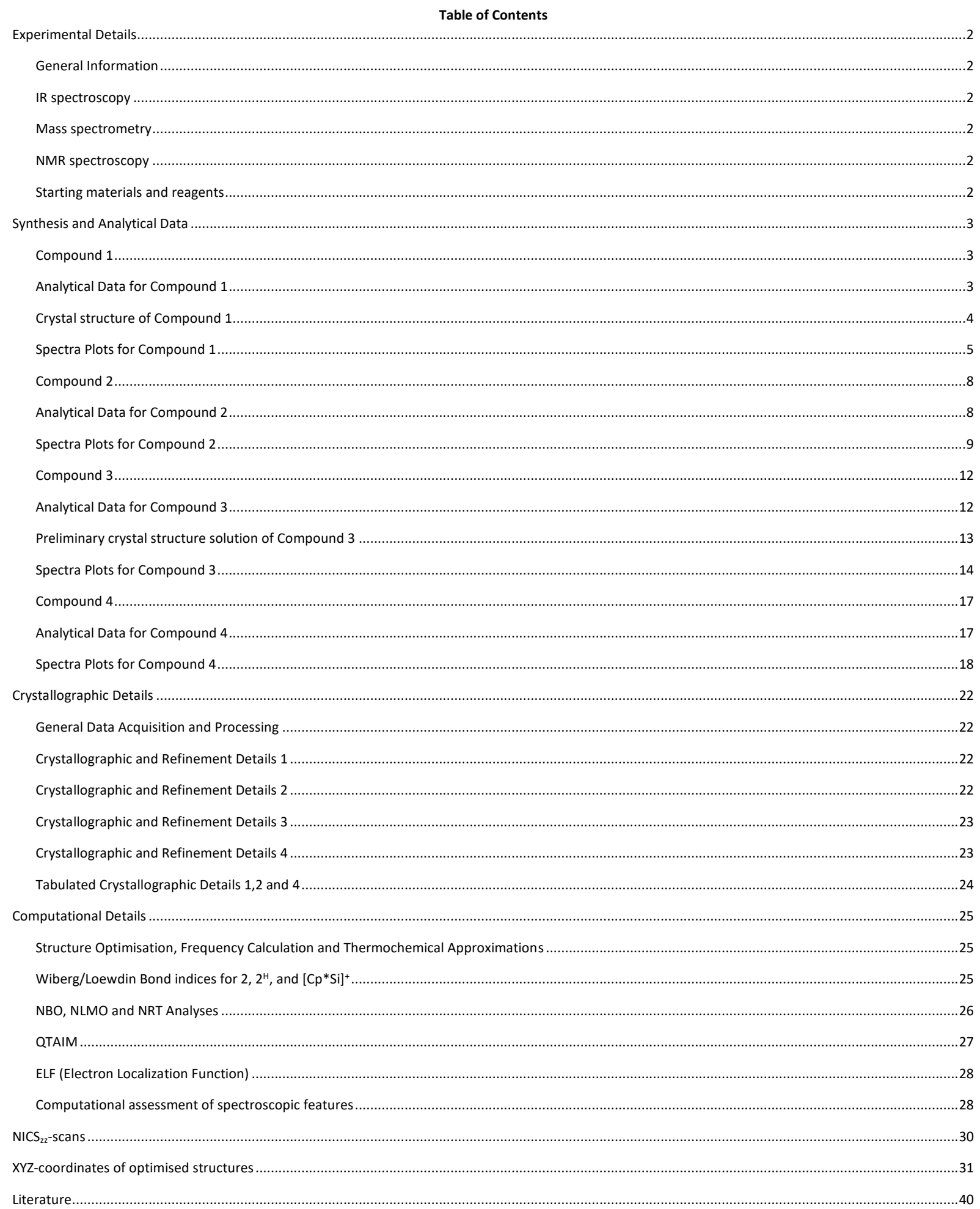




\section{Experimental Details}

\section{General Information}

All manipulations requiring handling under inert conditions were carried out under argon atmosphere using standard Schlenk techniques or an MBraun Glovebox with an Ar atmosphere. Benzene was obtained from an MBraun SPS and stored over molecular sieves, toluene and ether were distilled from sodium. Fluorobenzene was dried over $\mathrm{P}_{2} \mathrm{O}_{5}$, and stored over molecular sieves (4 Å). Dichloromethane was distilled from $\mathrm{CaH}_{2}$. Hexane and pentane were distilled from $\mathrm{Na} / \mathrm{K}$ alloy. THF

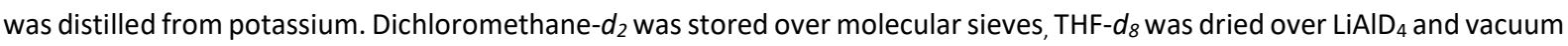
transferred, benzene- $d_{6}$ was distilled from potassium, and solvents were degassed and stored in a glove box. All solvents were routinely degassed three times using freeze-pump-thaw cycles.

Elemental analysis was performed by the Analytisches Labor, Institut für Anorganische Chemie, Universität Göttingen

\section{IR spectroscopy}

IR spectra were obtained on a Bruker ALPHA FT-IR spectrometer with Platinum ATR module.

\section{Mass spectrometry}

Mass spectra were recorded by the Zentrale Analytik within the Faculty of Chemistry, Göttingen applying a Liquid Injection Field Desorption Ionisation-technique on a JEOL accuTOF instrument with an inert-sample application setup under argon atmosphere. The injection capillary was washed several times with dry, distilled and inertly injected toluene before the samples were injected. Samples usually had a concentration of $1-2 \mathrm{mmol} / \mathrm{L}$ in toluene with a minimum amount of fluorobenzene added to guarantee solubility and were prepared in a glovebox.

\section{NMR spectroscopy}

NMR spectra were recorded with either a Bruker Avance III 400 NMR spectrometer equipped with a 5 mm BBFO ATM probe head and operating at $400.13\left({ }^{1} \mathrm{H}\right), 100.61\left({ }^{13} \mathrm{C}\right), 128.38\left({ }^{11} \mathrm{~B}\right)$ and $376.45 \mathrm{MHz}\left({ }^{19} \mathrm{~F}\right)$ along with a variable temperature set-up or a Bruker Avance Neo 400 NMR spectrometer with a CryoProbeProdigy BB ATM probe head operating at $400.25 \mathrm{MHz}\left({ }^{1} \mathrm{H}\right)$ and $100.65 \mathrm{MHz}\left({ }^{13} \mathrm{C}\right)$ or a Bruker AVIII HD 500 NMR spectrometer with a CryoProbeProdigy ATM probe head and operating at $500.25\left({ }^{1} \mathrm{H}\right), 125.80\left({ }^{13} \mathrm{C}\right), 160.50 \mathrm{MHz}\left({ }^{11} \mathrm{~B}\right)$ and $99.37 \mathrm{MHz}\left({ }^{29} \mathrm{Si}\right)$ or a Bruker Avance III HD spectrometer operating at 116.64 $\mathrm{MHz}\left({ }^{7} \mathrm{Li}\right)$. Chemical shifts are reported in $\delta$ values in ppm relative to external $\mathrm{Me}_{4} \mathrm{Si}$ and, if not otherwise stated, referenced using the chemical shift of the solvent ${ }^{2} \mathrm{H}$ lock resonance frequency and $\equiv=19.867187 \%$ for ${ }^{29} \mathrm{Si}, \equiv=38.863797 \%$ for ${ }^{7} \mathrm{Li}$, $\equiv=$ $32.083974 \%$ for ${ }^{11} \mathrm{~B}$, and $\equiv=94.094011 \%$ for ${ }^{19} \mathrm{~F} \cdot{ }^{[1]}{ }^{1} \mathrm{H}$ and ${ }^{13} \mathrm{C}$ spectra have been referenced on specific values for the respective solvent signal. The proton and carbon signals were assigned where possible via a detailed analysis of ${ }^{1} \mathrm{H},{ }^{13} \mathrm{C},{ }^{1} \mathrm{H}$ ${ }^{1} \mathrm{H}$ COSY, ${ }^{1} \mathrm{H}-{ }^{1} \mathrm{H}$ NOESY, ${ }^{1} \mathrm{H}-{ }^{13} \mathrm{C}$ HSQC, ${ }^{1} \mathrm{H}-{ }^{13} \mathrm{C}$ HMBC NMR spectra.

Young-type teflon-valve borosilicate NMR tubes have been used throughout the study.

\section{Starting materials and reagents}

1,3,4-(3', $5^{\prime}-t \mathrm{Bu}_{2}\left(\mathrm{C}_{6} \mathrm{H}_{3}\right)-2,5-\left(\mathrm{SiMe}_{3}\right)$-Borole $\mathbf{A}$ was prepared as recently reported. ${ }^{[2]}$

$\mathrm{Li}\left[\mathrm{Al}\left\{\mathrm{OC}\left(\mathrm{CF}_{3}\right)_{3}\right\}_{4}\right]$ was prepared according to the literature. ${ }^{[3]} \mathrm{LiAlH}_{4}\left(1 \mathrm{M}^{\mathrm{in} \mathrm{Et}} \mathrm{Et}_{2} \mathrm{O}\right)$ was obtained from Sigma Aldrich. Perfluoro-t-butanol was obtained from Fluorochem UK.

$\left.\operatorname{IPr}{ }^{[4]} \operatorname{IPr}\left(\mathrm{SiCl}_{2}\right)_{,}{ }^{[5]} \mathrm{Cp}_{2}{ }_{2} \mathrm{Si},{ }^{[6]}\left[\mathrm{H}(\mathrm{OEt})_{2}\right)_{2}\right]\left[\mathrm{Al}\left\{\mathrm{OC}\left(\mathrm{CF}_{3}\right)_{3}\right\}_{4}\right]^{[7]}$ were prepared as previously described in the literature.

[Cp*Si][AI $\left.\left\{\mathbf{O C}\left(\mathrm{CF}_{3}\right)_{3}\right\}_{4}\right]$ was prepared along modified literature procedures. ${ }^{[6 \mathrm{~b},}$ 8] To a stirred solution of $\left[\mathrm{H}\left(\mathrm{OEt}_{2}\right)_{2}\right]\left[\mathrm{Al}\left\{\mathrm{OC}\left(\mathrm{CF}_{3}\right)_{3}\right\}_{4}\right](183.0 \mathrm{mg}, 163.9 \mu \mathrm{mol}, 1 \mathrm{eq}$.$) in fluorobenzene (2 \mathrm{~mL})$, a solution of decamethylsilicocene $(49.0 \mathrm{mg}$, $164.1 \mu \mathrm{mol}, 1$ eq.) in fluorobenzene $(0.5 \mathrm{~mL})$ was added dropwise. The initially yellow solution was stirred for $1 \mathrm{~h}$ at room temperature before the orange solution was concentrated under reduced pressure to approximately one half of the original volume. Cooled pentane $\left(-30^{\circ} \mathrm{C}, 15 \mathrm{~mL}\right)$ was added and an orange solid precipitated. The solid was washed with pentane (2 $\times 5 \mathrm{~mL}$ ) and the washing phases were decanted. After drying under reduced pressure, $[\mathrm{Cp} * \mathrm{Si}]\left[\mathrm{Al}\left\{\mathrm{OC}\left(\mathrm{CF}_{3}\right)_{3}\right\}_{4}\right]$ was obtained as a pale pink solid (179.4 mg, $158.7 \mu \mathrm{mol}, 97 \%)$. Spectroscopic features were identical to those previously reported. ${ }^{[8 \mathrm{~b}]}$ 


\section{Synthesis and Analytical Data}

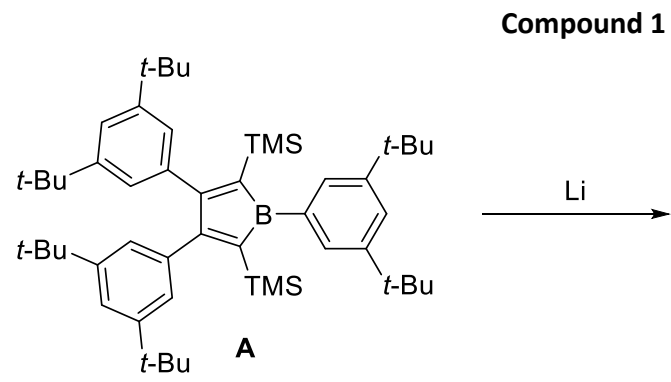

Molecular Weight: 773,2000

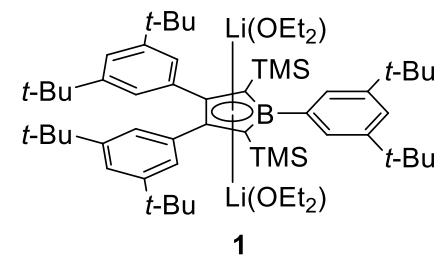

Molecular Weight: 935,3260

In a glovebox, borole A $(506.7 \mathrm{mg}, 0.655 \mathrm{mmol}, 1 \mathrm{eq})$ was dissolved in dry and degassed diethylether (13 mL). Li flakes $(22.7 \mathrm{mg}, 3.28 \mathrm{mmol}, 5 \mathrm{eq}$ ) were added to the solution and the solution was stirred overnight at ambient temperature. In the course of the reaction, the colour of the solution changed only slightly from a red to a red-yellow solution, and a small amount of a colourless precipitate formed. The solution was filtered through a syringe filter equipped with a thin plug of glass fiber and the filter was washed with diethylether $(2 \times 0.5 \mathrm{~mL})$. The solvent of the filtrate was removed under reduced pressure and the resulting red solid was washed with a small amount of cold hexane $\left(-40^{\circ} \mathrm{C}\right.$, starting with $1 \times 0.5 \mathrm{~mL}$, then $\left.2 \times 0.3 \mathrm{~mL}\right) \mathrm{until}$ the residual solid was of a pale yellow colour $\left(279.7 \mathrm{mg}\right.$ ). Storing the combined washing phases at $-40^{\circ} \mathrm{C}$ gave a second crop of crystals $(20.9 \mathrm{mg})$, which were washed with cold hexane $\left(-40^{\circ} \mathrm{C}, 3 \times 0.2 \mathrm{~mL}\right)$ and dried in vacuo. Compound 1 was obtained in combined yields as a pale yellow solid (300.6 mg, $0.321 \mathrm{mmol}, 49 \%)$.

Note: ${ }^{1} \mathrm{H}-\mathrm{NMR}$ spectroscopic analysis of an aliquot of the crude reaction mixture after stirring overnight indicated complete consumption of the starting material and the formation of compound $\mathbf{1}$ in essentially quantitative yield (>95\% purity based on NMR). However, after repeated crystallizations NMR spectroscopic analysis of the remaining mother liquor indicated decomposition of compound 1 to several unidentified compounds.

When the isolated crystals of compound 1 were dissolved in $\mathrm{C}_{6} \mathrm{D}_{6}$, stored at ambient temperature and monitored via ${ }^{1} \mathrm{H}-\mathrm{NMR}$ spectroscopy, no signs of decomposition were observed.

NMR:

\section{Analytical Data for Compound 1}

${ }^{1} \mathrm{H}\left(500.25 \mathrm{MHz}, 298 \mathrm{~K}, \mathrm{C}_{6} \mathrm{D}_{6}, \mathrm{CD}_{5} \mathrm{H}\right.$ at $\left.7.15 \mathrm{ppm}\right): 7.71\left(\mathrm{br}, 2 \mathrm{H}, o-H_{\text {arr }}\right), 7.48\left(\mathrm{t},{ }^{4} J_{\mathrm{HH}}=1.9 \mathrm{~Hz}, 1 \mathrm{H}, p-H_{\text {ar1 }}\right), 7.21\left(\mathrm{t},{ }^{4} J_{\mathrm{HH}}=1.8 \mathrm{~Hz}\right.$, $\left.2 \mathrm{H}, p-H_{a r 3,4}\right), 6.98\left(\mathrm{br}, 4 \mathrm{H}, o-H_{a r 3,4}\right), 3.26\left(\mathrm{q},{ }^{3} \mathrm{~J}_{\mathrm{HH}}=7.1 \mathrm{~Hz}, 8 \mathrm{H}, \mathrm{OCH}_{2} \mathrm{CH}_{3}\right), 1.61\left(\mathrm{~s}, 18 \mathrm{H}, \mathrm{Ar}_{1}-\mathrm{C}(M e)_{3}\right), 1.31\left(\mathrm{~s}, 36 \mathrm{H}, \mathrm{Ar}_{3,4}-\mathrm{C}\left(\mathrm{Me}_{3}\right)\right.$, $1.02\left(\mathrm{t}, 3^{3} \mathrm{HH}=7.1 \mathrm{~Hz}, 12 \mathrm{H}, \mathrm{OCH}_{2} \mathrm{CH}_{3}\right), 0.20\left(\mathrm{~s}, 18 \mathrm{H}, \mathrm{Si}(\mathrm{Me})_{3}\right)$.

${ }^{13} \mathrm{C}\left\{{ }^{1} \mathrm{H}\right\}\left(100.65 \mathrm{MHz}, 298 \mathrm{~K}, \mathrm{C}_{6} \mathrm{D}_{6}\right.$, solvent signal at $\left.128.0 \mathrm{ppm}\right): 151.5$ (ipso- $\left.C_{a r 1}\right), 148.8\left(m-C_{a r 3,4}\right), 147.1\left(m-C_{\text {Ar1 }}\right), 144.3$ (ipso$\left.C_{a r 3,4}\right), 131.7$ (borole- $\left.C_{3,4}\right), 130.4\left(o-C_{a r 1}\right), 126.6\left(o-C_{a r 3,4}\right), 117.4\left(p-C_{a r 3,4}\right), 117.3\left(p-C_{a r 1}\right), 103.9$ (borole- $\left.C_{2,5}\right), 65.7\left(\mathrm{OCH}_{2} \mathrm{CH}_{3}\right)$, $35.0\left(\mathrm{Ar}_{1}-\mathrm{C}\left(\mathrm{CH}_{3}\right)_{3}\right), 34.7\left(\mathrm{Ar}_{3,4}-\mathrm{C}\left(\mathrm{CH}_{3}\right)_{3}\right), 32.3\left(\mathrm{Ar}_{1}-\left(\mathrm{C}\left(\mathrm{CH}_{3}\right)_{3}\right), 31.8\left(\mathrm{Ar}_{3.4}-\left(\mathrm{C}\left(\mathrm{CH}_{3}\right)_{3}\right), 15.2\left(\mathrm{OCH}_{2} \mathrm{CH}_{3}\right), 4.9\left(\mathrm{Si}\left(\mathrm{CH}_{3}\right)_{3}\right)\right.\right.$.

${ }^{7} \mathrm{Li}\left(116.64 \mathrm{MHz}, 298 \mathrm{~K}, \mathrm{C}_{6} \mathrm{D}_{6}\right):-5.9$.

${ }^{11} \mathbf{B}\left(160.50 \mathrm{MHz}, 298 \mathrm{~K}, \mathrm{C}_{6} \mathrm{D}_{6}\right): 36.6$.

${ }^{29} \mathrm{Si}$-INEPT $\left(99.38 \mathrm{MHz}, 298 \mathrm{~K}, \mathrm{C}_{6} \mathrm{D}_{6}\right):-12.7$.

Elemental Analysis: $\mathrm{C}_{60} \mathrm{H}_{101} \mathrm{BLi}_{2} \mathrm{O}_{2} \mathrm{Si}_{2}$ calcd C 77.05, H 10.88; observed C 76.70, H 11.06. 
For further details on the diffraction measurement please see the respective section.

1 crystallized from solutions in hexane in a freezer $\left(-40^{\circ} \mathrm{C}\right)$.

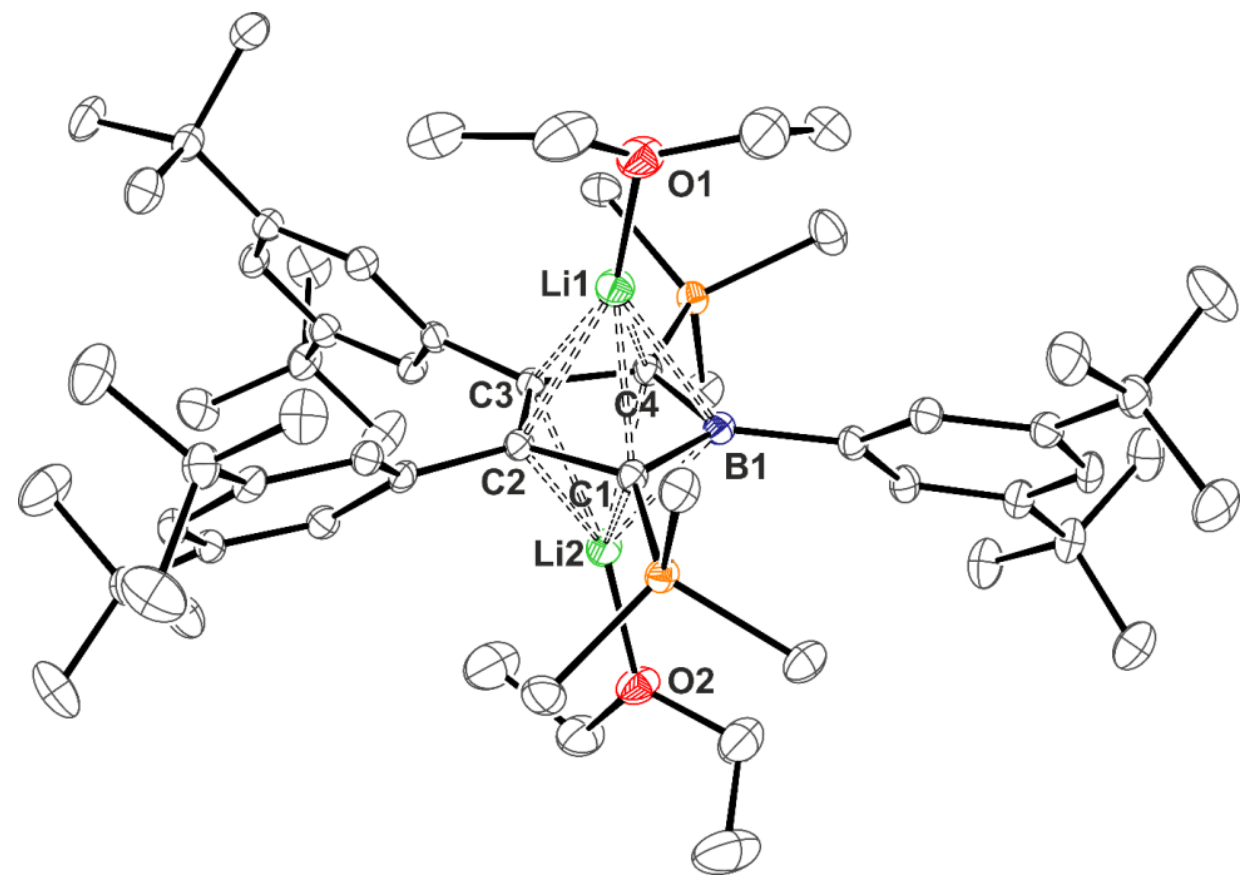

Figure S1: ORTEP plot of the molecular structure of 1. Atomic displacement parameters are drawn at 50\% probability level. Disorder of one $t \mathrm{Bu}$ group and hydrogen atoms are omitted for the sake of clarity. Selected bond length in $\AA$ : B1-C1 1.550(2), C1-C2 1.465(2), C2-C3 1.434(2), C3-C4 1.461(2), C4-B1 1.553(2), B1-Li1 2.235(3), C1-Li1 2.202(3), C2-Li1 2.180(3), C3-Li1 2.191(3), C4-Li1 2.235(3), Li1-O1 1.960(2), B1-Li2 2.213(3), C1-Li2 2.199(3), C2-Li2 2.175(3), C3-Li2 2.189(2), C4-Li2 2.218(3), Li2-O2 1.899(2). The structure was deposited with the CCSD. 
Spectra Plots for Compound 1

1H-NMR-spectrum of
$1-\left(3^{\prime}, 5^{\prime}-\right.$ tBu2 (C6H3)) $-2,5-($ SiMe3) 2-3,4-(3', 5'-tBu2 (C6H3)) 2-borole * [Li (OEt2) 2 in C 6 D 6 \# referenced to $\mathrm{C}_{6} \mathrm{D}_{5} \mathrm{H}$ at $7.15 \mathrm{ppm}$

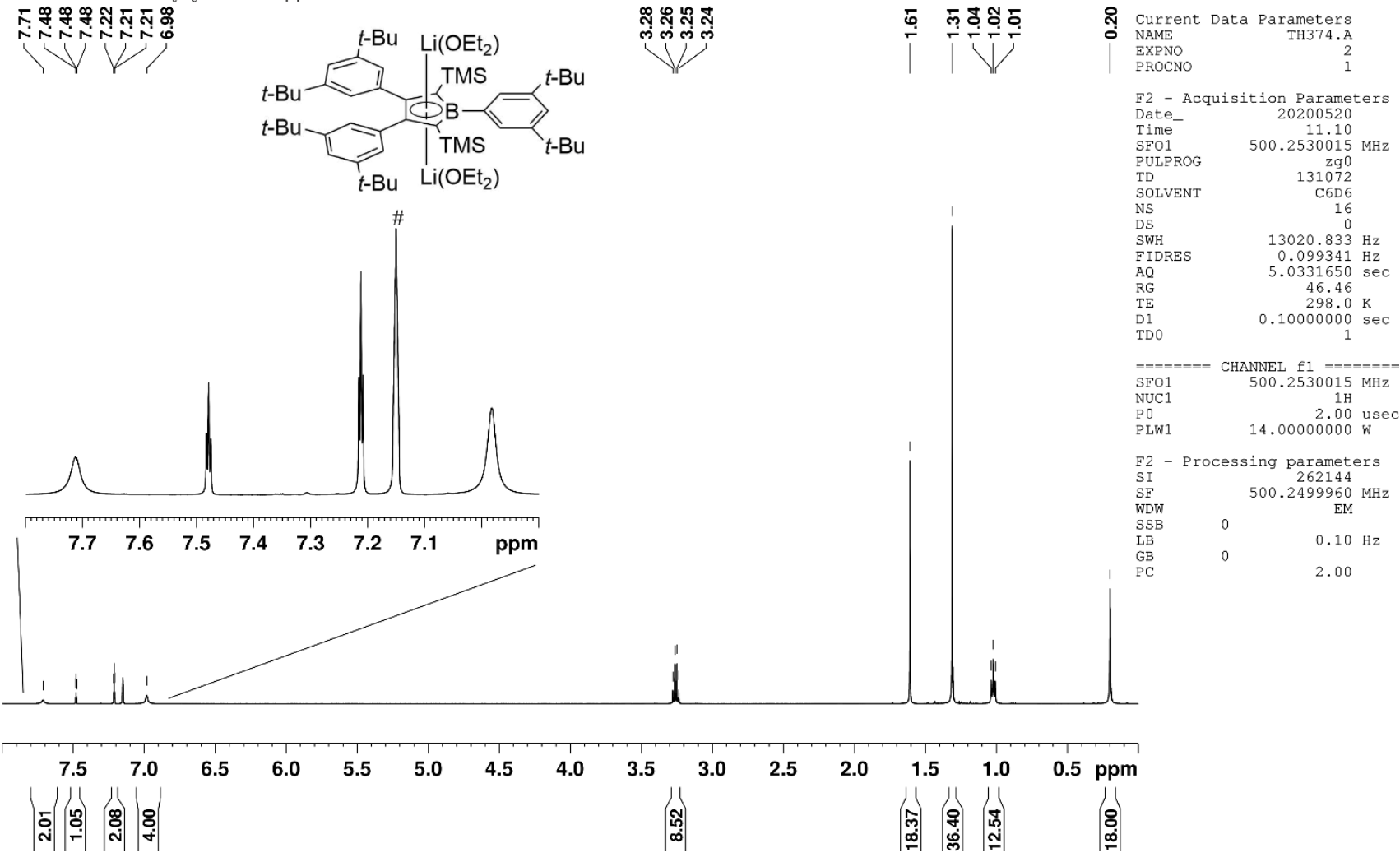

$13 \mathrm{C}\{1 \mathrm{H}\}-\mathrm{NMR}-$ spect rum of

$1-\left(3^{\prime}, 5^{\prime}-\mathrm{tBu} 2(\mathrm{C} 6 \mathrm{H} 3)\right)-2,5-(\mathrm{SiMe} 3) 2-3,4-\left(3^{\prime}, 5^{\prime}-\mathrm{tBu} 2(\mathrm{C} 6 \mathrm{H} 3)\right) 2$-borole * [ Li (OEt2) 2 in C6D 6 \# referenced to $C_{6} D_{6}$ at $128.0 \mathrm{ppm}$

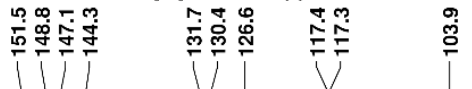
|

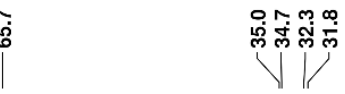

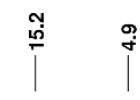

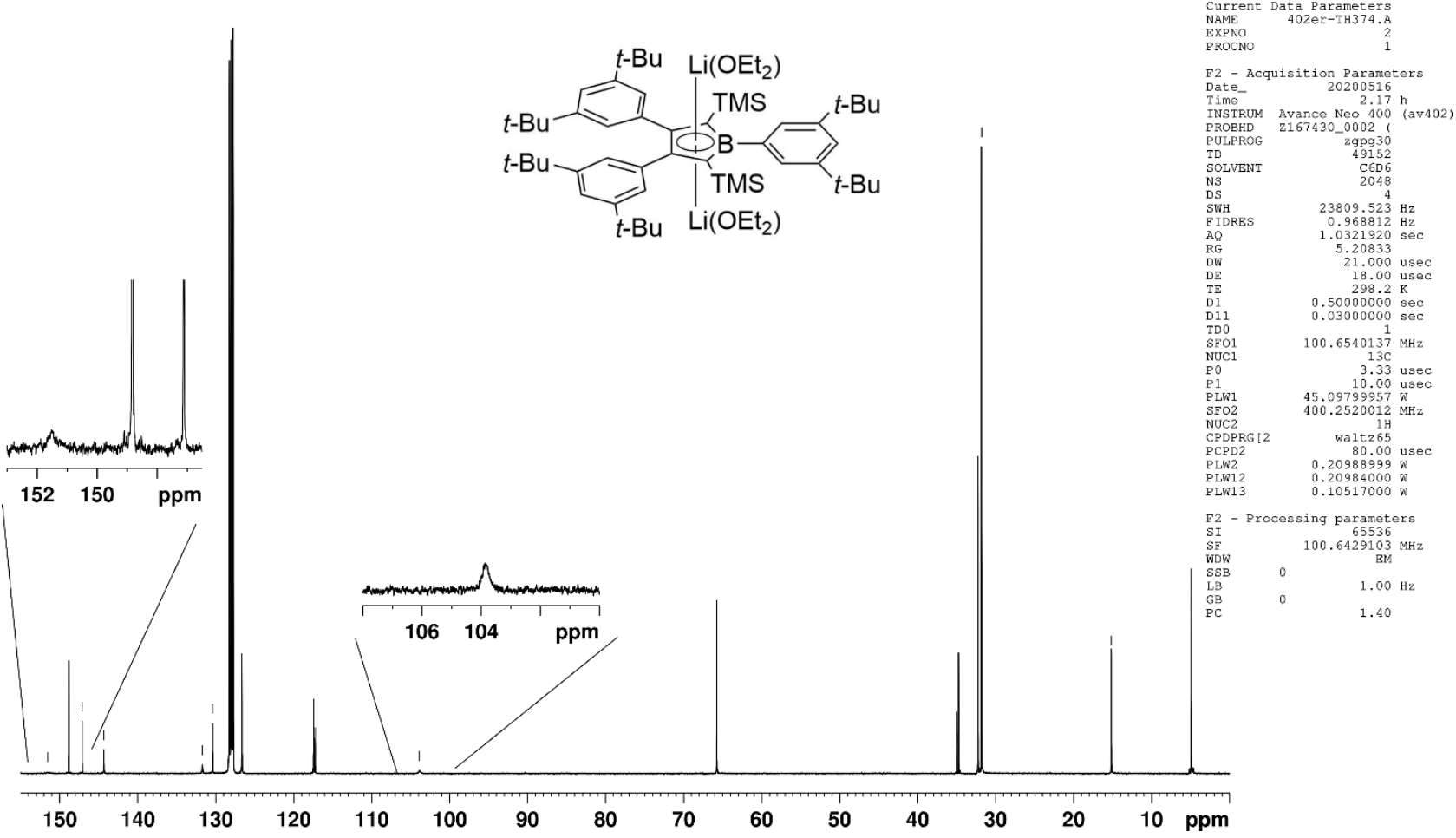


$7 \mathrm{Li}-\mathrm{NMR}-$ spectrum of

$1-\left(3^{\prime}, 5^{\prime}-\mathrm{tBu} 2(\mathrm{C} 6 \mathrm{H} 3)\right)-2,5-(\mathrm{SiMe} 3) 2-3,4-\left(3^{\prime}, 5^{\prime}-\mathrm{tBu} 2(\mathrm{C} 6 \mathrm{H} 3)\right) 2$-borole * [Li (OEt2)] 2 in C6D6

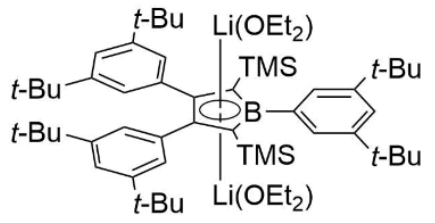

$\begin{array}{lr}\text { Current } & \text { Data Parameters } \\ \text { NAME } & \text { 301er-TH374. A } \\ \text { EXPNO } & 2 \\ \text { PROCNO } & \text { 1 }\end{array}$

F2- Acquisition Parameters
20200515

$\begin{array}{lr}\text { Date- } & 20200515 \\ \text { Time- } & 13.33\end{array}$

$\begin{array}{lr}\text { INSTRUM } & \text { spect } \\ \text { PROBHD } & \text { z104275_0147 }\end{array}$

$\begin{array}{lr}\text { PROBHD } & \text { Z104275_0147 } \\ \text { PULPROG } & \text { zgdc30 } \\ \text { PUD } & 8192\end{array}$

SOLVENT

$\begin{array}{ll}\text { DS } & 2 \\ \text { SWH } & 4084.967 \mathrm{~Hz} \\ \text { FIDRES } & 0.997306 \mathrm{~Hz}\end{array}$

$\begin{array}{lr}\text { FIDRES } & 0.997306 \mathrm{~Hz} \\ \text { AQ } & 1.0027008 \mathrm{sec}\end{array}$

-Bu $\mathrm{Li}\left(\mathrm{OEt}_{2}\right)$

122.400 usec

$298.1 \mathrm{~K}$

$0.03000000 \mathrm{sec}$

$116.6419140 \mathrm{MHz}$

9.00 usec

$20.00000000 \mathrm{~W}$
$300.1315007 \mathrm{MHz}$

$1 \mathrm{H}$
waltz16

$\begin{array}{lr}\text { PCPD2 } & 90.00 \text { usec } \\ \text { PLW2 } & 10.00000000 \mathrm{w} \\ \text { PLW12 } & 0.16611999 \mathrm{~W}\end{array}$

F2 - Processing parameters

SF
WSB

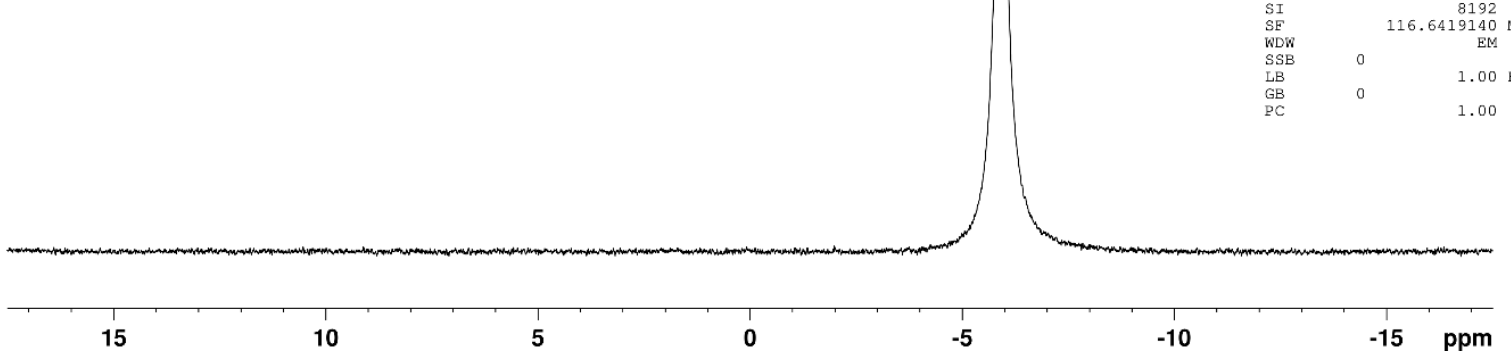

11B-NMR spectrum (without background suppression) of

$1-\left(3^{\prime}, 5^{\prime}-\mathrm{tBu} 2(\mathrm{C} 6 \mathrm{H} 3)\right)-2,5-(\mathrm{SiMe} 3) 2-3,4-\left(3^{\prime}, 5^{\prime}-\mathrm{tBu} 2(\mathrm{C} 6 \mathrm{H} 3)\right) 2$-borole * [Li (OEt2) ] 2 in C6D 6
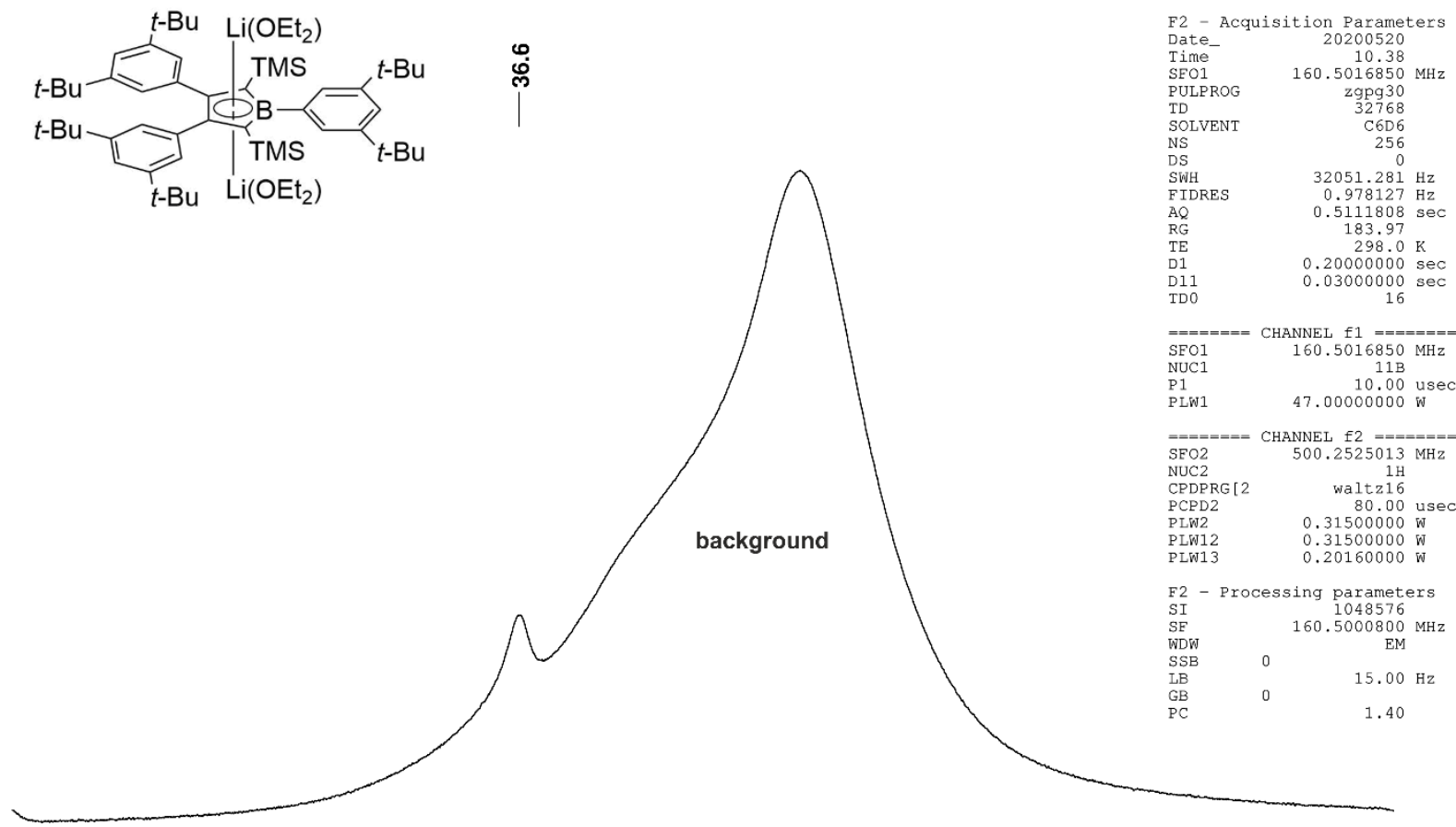

$\begin{array}{llllllllllllllllllllll}100 & 90 & 80 & 70 & 60 & 50 & 40 & 30 & 20 & 10 & 0 & -10 & -20 & -30 & -40 & -50 & -60 & -70 & \mathrm{ppm}\end{array}$ 
29Si-INEPT-NMR-spect rum of
$1-\left(3^{\prime}, 5^{\prime}-\mathrm{tBu} 2(\mathrm{C} 6 \mathrm{H} 3)\right)-2,5-(\mathrm{SiMe} 3) 2-3,4-\left(3^{\prime}, 5^{\prime}-\mathrm{tBu} 2(\mathrm{C} 6 \mathrm{H} 3)\right) 2$-borole * [Li (OEt2) 2 in C $6 \mathrm{D} 6$

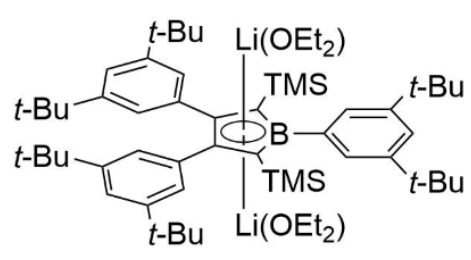

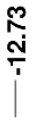

Current Data Parameters

EXPNO

F2 - Acquisition Parameters
Date_- 20200520

$\begin{array}{lc}\text { Date } & 20200520 \\ \text { Time } & 10.56 \\ \text { SFO1 } & 99.3844104 \mathrm{MHz} \\ \text { PULPROG } & \text { ineptrdsp } \\ \text { PULPR } & 3278\end{array}$

TD

NS

$\begin{array}{ll}\text { DS } & 16 \\ \text { SWH } & 11904.762 \mathrm{~Hz}\end{array}$

$\begin{array}{ll}\text { SWH } & 11904.762 \mathrm{~Hz} \\ \text { FIDRES } & 0.36304 \mathrm{~Hz} \\ \text { AO } & 1.3762560 \mathrm{sec}\end{array}$

$\begin{array}{lr}\text { RG } & 183.97 \\ \text { TE } & 298.0 \mathrm{~K}\end{array}$

$\begin{array}{lr}\text { CNST2 } & 7.0000000 \\ \text { CNST11 } & 18.0000000\end{array}$

$\begin{array}{ll}\text { CNST17 } & -0.5000000 \\ \text { D1 } & 1.0000000 \mathrm{sec} \\ \text { D3 } & 0.00793651 \mathrm{sec} \\ \text { D4 } & 0.03571429 \mathrm{sec}\end{array}$

$\begin{array}{ll}\text { D4 } & 0.03571429 \mathrm{sec} \\ \text { D12 } & 0.00002000 \mathrm{sec} \\ \text { DD } & \end{array}$

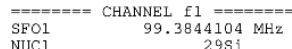

$\begin{array}{ll}\text { P1 } & 11.30 \text { used } \\ \text { P13 } & 2000.00 \text { usec }\end{array}$

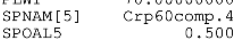

SPOALFS5
SPFS

$=======$
SFO2
NUC2
CHANNEL $\mathrm{f} 2=======$
500.2525013 MHz
$1 \mathrm{H}$

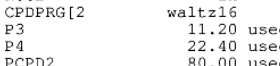

P4
PCPD2
PIN2

PLW12 $\quad 0.31500000$ w

F2 - Processing parameters

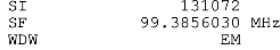

$\begin{array}{lll}\substack{\text { NDW } \\ S S B B} & 0 & 0.50 \mathrm{~Hz} \\ \mathrm{LB} & 0 & 0.50 \mathrm{~Hz} \\ \mathrm{~GB} & 0 & 1.40\end{array}$

$\begin{array}{lll}\underset{\mathrm{GB}}{\mathrm{PC}} & 0 & 1.40\end{array}$

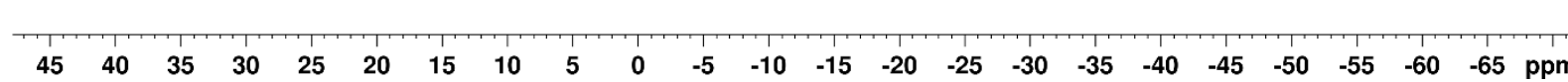


<smiles>CCOC(C)(C)C(C)(C)C(C)(C)C</smiles>

In a glovebox, compound 1 (352.7 $\mathrm{mg}, 0.377 \mathrm{mmol}, 1 \mathrm{eq})$ was dissolved in dry and degassed diethylether $(10 \mathrm{~mL})$. $[\mathrm{Cp} * \mathrm{Si}]\left[\mathrm{Al}\left\{\mathrm{OC}\left(\mathrm{CF}_{3}\right)_{3}\right\}_{4}\right](937.8 \mathrm{mg}, 0.83 \mathrm{mmol}, 2.2 \mathrm{eq})$ was added as a solution in diethylether $(20 \mathrm{~mL})$. The resulting pale yellow solution was stirred at ambient temperature for $48 \mathrm{~h}$, whereupon an aliquot $(0.7 \mathrm{~mL})$ was taken. The solvent of the aliquot was removed under reduced pressure and the residue was extracted with $\mathrm{C}_{6} \mathrm{D}_{6}(0.5 \mathrm{~mL})$. NMR spectroscopic analysis indicated $90 \%$ consumption of compound 1 , therefore the reaction was stirred for further $72 \mathrm{~h}$ at ambient temperature. After this time an aliquot was taken again and showed $95 \%$ consumption of compound 1. Additional [Cp*Si][Al\{OOC( $\left.\left.\left.\mathrm{CF}_{3}\right)_{3}\right\}_{4}\right](85.2 \mathrm{mg}$, $0.075 \mathrm{mmol}, 0.2 \mathrm{eq}$ ) was added to the reaction mixture and stirring was continued overnight. The solvent of the pale yellow reaction mixture was removed under reduced pressure and the resulting sticky solid was suspended in dry and degassed hexane $(4 \mathrm{~mL})$. The resulting suspension was filtered through a syringe filter equipped with a thin plug of glass fiber and the filter was washed with hexane $(5 \times 1 \mathrm{~mL})$. The solvent of the filtrate was removed under reduced pressure to obtain a pale yellow solid. This solid was found to be a mixture of almost exclusively 2 and $\mathrm{Cp}_{2}{ }_{2} \mathrm{Si}$ and was dissolved in hexane (1.6 mL) and stored overnight at $-40{ }^{\circ} \mathrm{C}$ to yield a first crop of colourless crystals, which were isolated and washed with cold hexane ($40{ }^{\circ} \mathrm{C}, 2 \times 0.2 \mathrm{~mL}$ ). After three more crystallisation crops compound 2 was obtained in a combined yield as a colourless solid (186.6 mg, $0.233 \mathrm{mmol}, 62 \%)$.

Crystals suitable for $x$-ray crystallography were grown from a saturated hexane solution at $-40{ }^{\circ} \mathrm{C}$.

\section{NMR:}

\section{Analytical Data for Compound 2}

${ }^{1} \mathrm{H}\left(500.25 \mathrm{MHz}, 298 \mathrm{~K}, \mathrm{C}_{6} \mathrm{D}_{6}, \mathrm{CD}_{5} \mathrm{H}\right.$ at $\left.7.15 \mathrm{ppm}\right): 7.77\left(\mathrm{~d},{ }^{4} J_{\mathrm{HH}}=1.9 \mathrm{~Hz}, 2 \mathrm{H}, o-H_{\text {ar1 }}\right), 7.54\left(\mathrm{t},{ }^{4} J_{\mathrm{HH}}=1.9 \mathrm{~Hz}, 1 \mathrm{H}, p-H_{\text {ar1 }}\right), 7.27(\mathrm{t}$, $\left.{ }^{4} J_{\mathrm{HH}}=1.8 \mathrm{~Hz}, 2 \mathrm{H}, p-\mathrm{H}_{\text {ar } 3,4}\right), 7.18-7.27\left(\mathrm{br}, 4 \mathrm{H}, o-\mathrm{H}_{\text {ar3 } 34}\right), 1.46\left(\mathrm{~s}, 18 \mathrm{H}, \mathrm{Ar}_{1}-\mathrm{C}(M e)_{3}\right), 1.19\left(\mathrm{br} \mathrm{s}, 36 \mathrm{H}, \mathrm{Ar}_{3,4}-\mathrm{C}(M e)_{3}\right), 0.04(\mathrm{~s}, 18 \mathrm{H}$, $\left.\mathrm{Si}(\mathrm{Me})_{3}\right)$.

${ }^{13} \mathrm{C}\left\{{ }^{1} \mathrm{H}\right\}\left(125.80 \mathrm{MHz}, 298 \mathrm{~K}, \mathrm{C}_{6} \mathrm{D}_{6}\right.$, solvent signal at $\left.128.0 \mathrm{ppm}\right): 150.2\left(m-C_{\text {ar3 } 34}\right), 149.0\left(m-C_{\text {Ar1 }}\right), 141.8$ (ipso- $\left.C_{\text {ar1 }}\right), 139.2$ (borole- $C_{3,4}$ ), 135.6 (ipso- $\left.C_{a r 3,4}\right), 129.1$ (o- $\left.C_{a r 1}\right), 126.2\left(o-C_{a r 3,4}\right), 120.9\left(p-C_{a r 3,4}\right), 119.9\left(p-C_{a r 1}\right), 110.4$ (borole- $\left.C_{2,5}\right), 34.9\left(\operatorname{Ar}_{1}\right.$ $\left.\mathrm{C}\left(\mathrm{CH}_{3}\right)_{3}\right), 34.7\left(\mathrm{Ar}_{3,4}-\mathrm{C}\left(\mathrm{CH}_{3}\right)_{3}\right), 31.8\left(\mathrm{Ar}_{1-}-\left(\mathrm{C}\left(\mathrm{CH}_{3}\right)_{3}\right), 31.4\left(\mathrm{Ar}_{3.4}-\left(\mathrm{C}\left(\mathrm{CH}_{3}\right)_{3}\right), 1.8\left(\mathrm{Si}\left(\mathrm{CH}_{3}\right)_{3}\right)\right.\right.$.

${ }^{11} \mathrm{~B}\left(128.38 \mathrm{MHz}, 298 \mathrm{~K}, \mathrm{C}_{6} \mathrm{D}_{6}\right): 31.5\left(v_{1 / 2} \approx 1100 \mathrm{~Hz}\right)$.

${ }^{29} \mathrm{Si}\left\{{ }^{1} \mathrm{H}\right\}\left(79.49 \mathrm{MHz}, 298 \mathrm{~K}, \mathrm{C}_{6} \mathrm{D}_{6}\right):-6.8\left(\mathrm{Si}(\mathrm{Me})_{3}\right),-349.36$ (borole-Si, additional signal at -349.32 for ${ }^{10} \mathrm{~B}$ isotopologue).

Elemental Analysis: $\mathrm{C}_{52} \mathrm{H}_{81} \mathrm{BSi}_{3}$ calcd C 77.95, H 10.19; observed C 75.13, H 9.85 (best analysis obtained).

LIFDI-MS: calcd exact mass: $800.6 \mathrm{~m} / \mathrm{z}$; observed m/z: $800.4[\mathrm{M}]^{+}$. 
1H-NMR-spectrum of compound 2 in C6D 6 \# referenced to $\mathrm{C}_{6} \mathrm{D}_{5} \mathrm{H}$ at $7.15 \mathrm{ppm}$

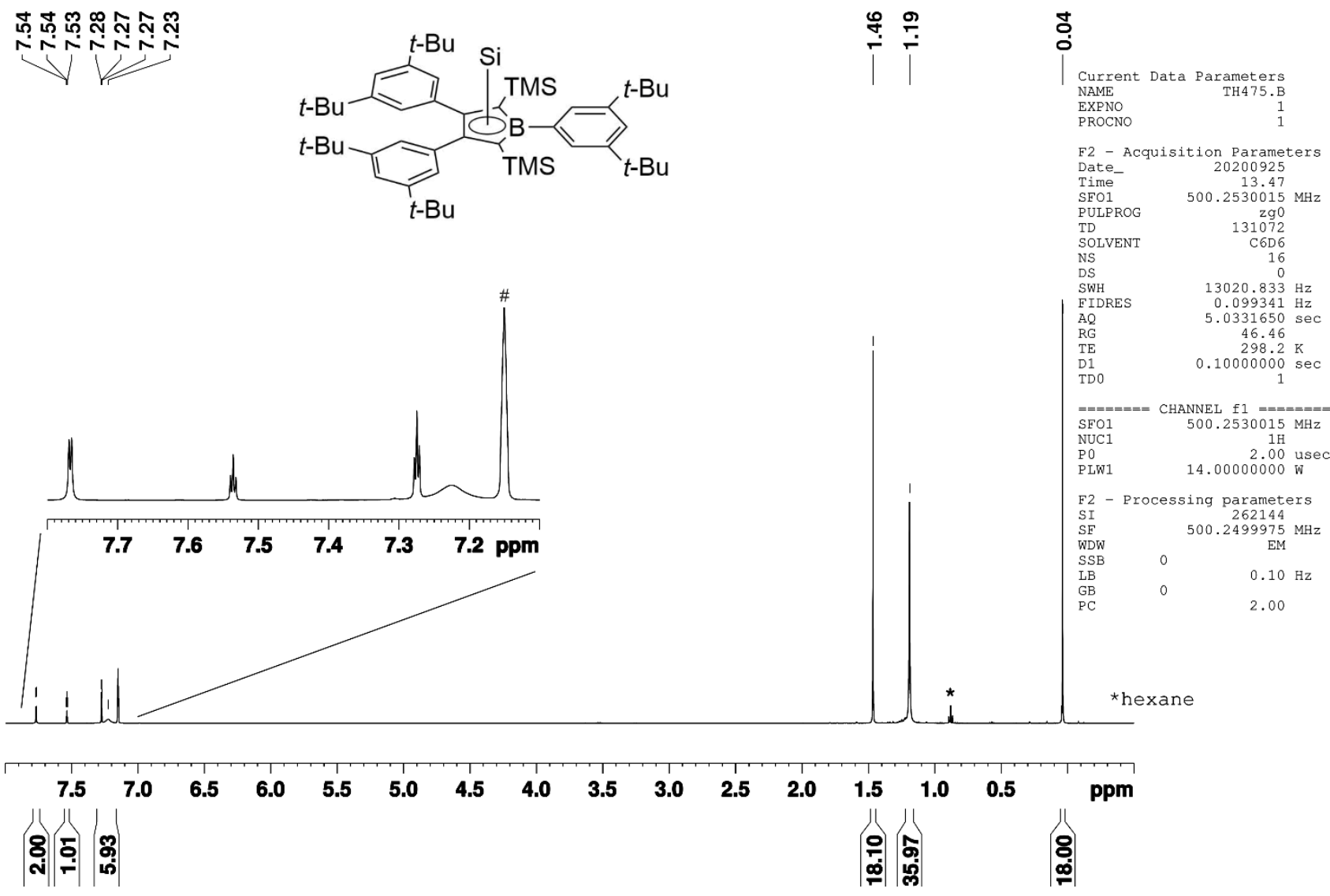

$13 \mathrm{C}\{1 \mathrm{H}\}-\mathrm{NMR}$-spectrum of compound 2 in C6D 6

\# referenced to $\mathrm{C}_{6} \mathrm{D}_{6}$ at $128.0 \mathrm{ppm}$

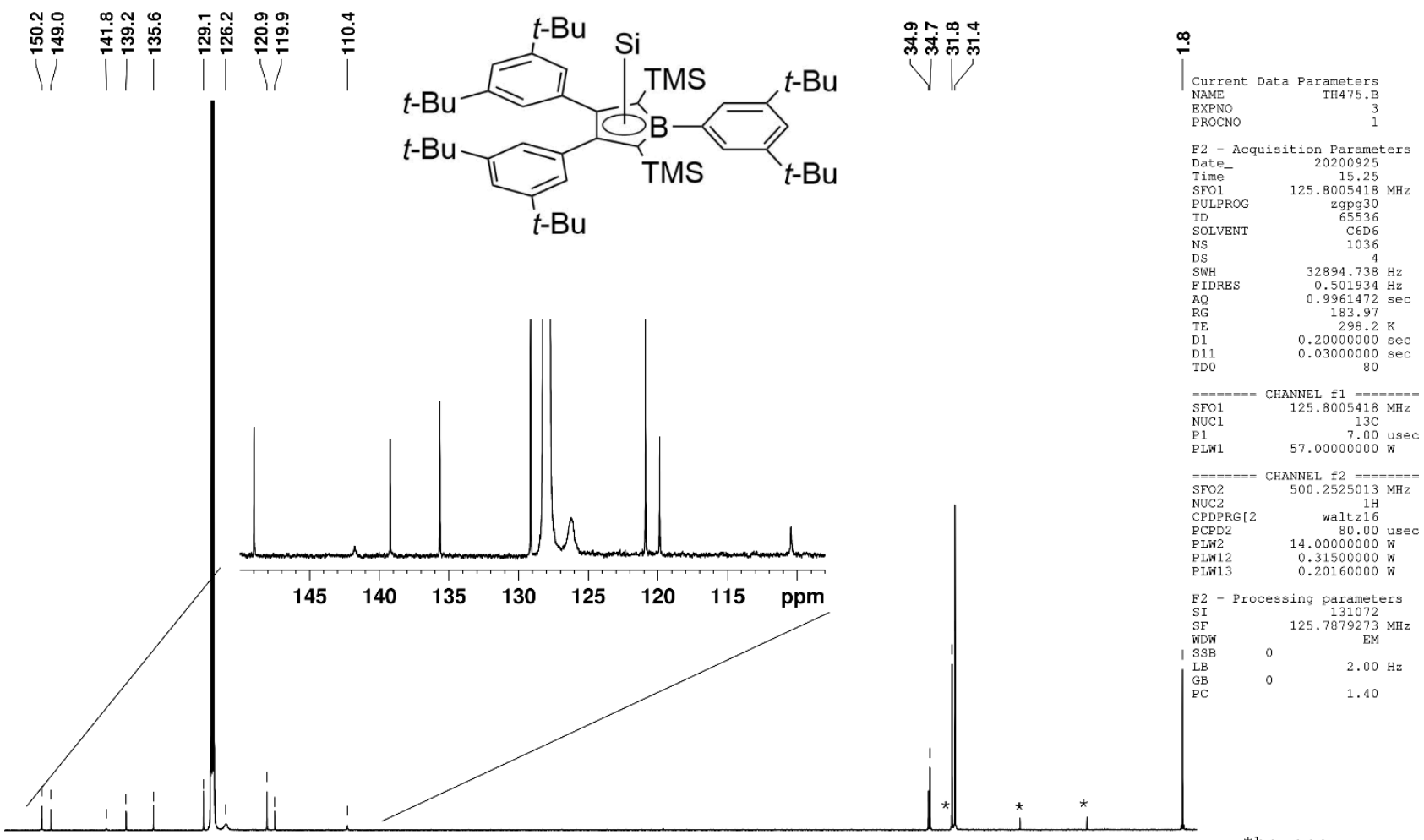

*hexane

$\begin{array}{lllllllllllllll}150 & 140 & 130 & 120 & 110 & 100 & 90 & 80 & 70 & 60 & 50 & 40 & 30 & 20 & 10\end{array}$ 
11B-NMR spectrum (background suppressed) of compound 2 in C6D6

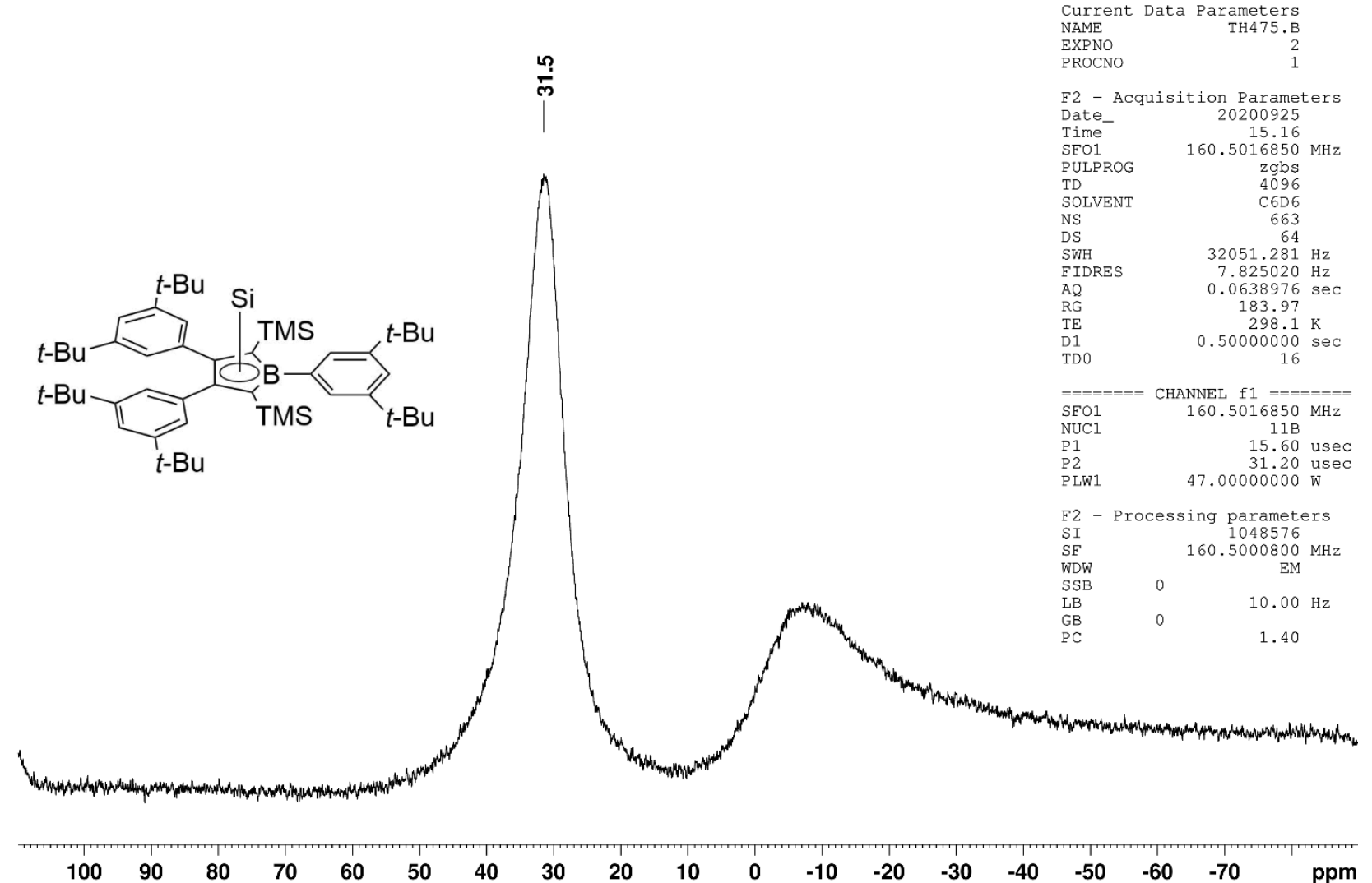

29Si $\{1 \mathrm{H}\}-\mathrm{NMR}$-spectrum of compound 2 in C6D 6

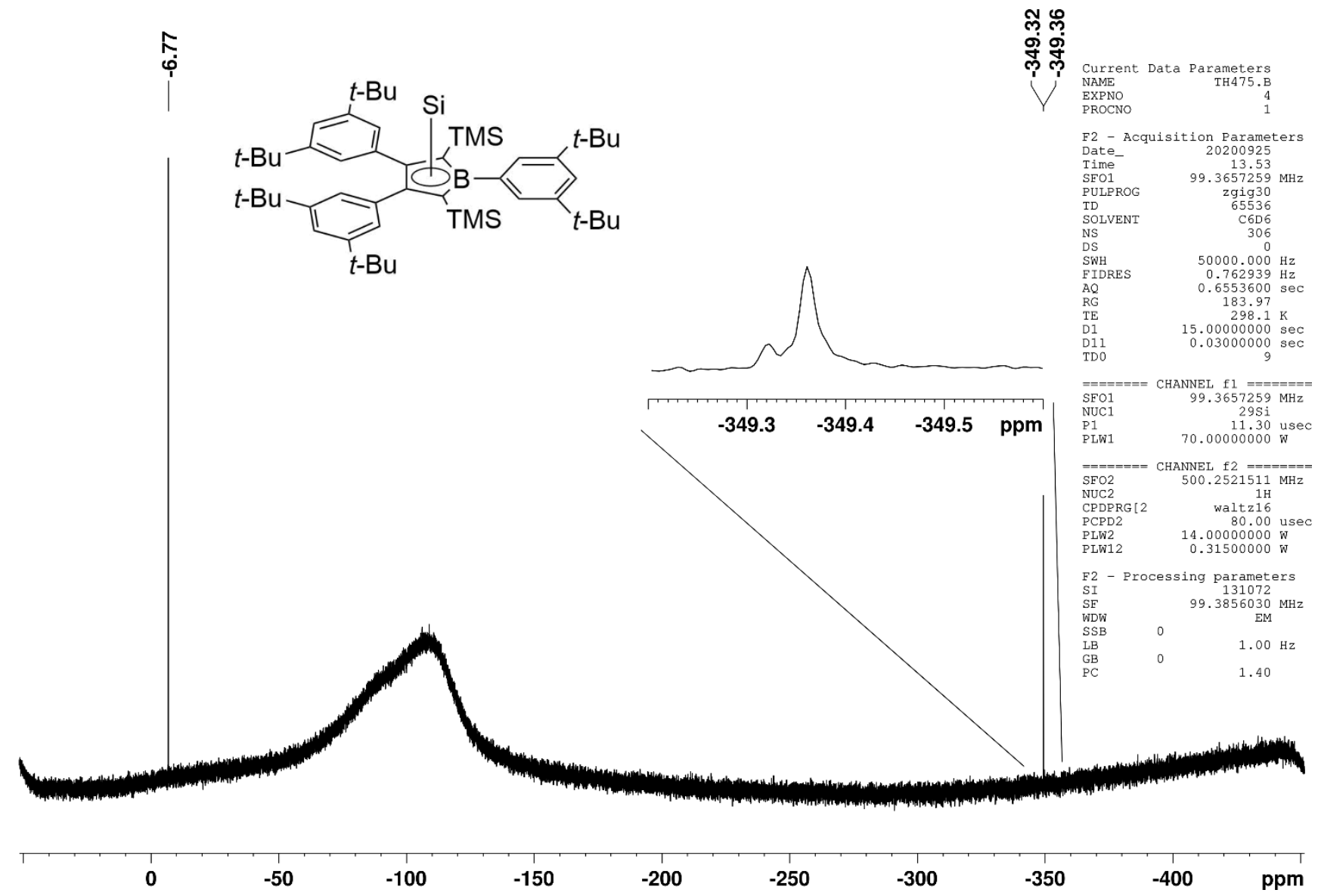




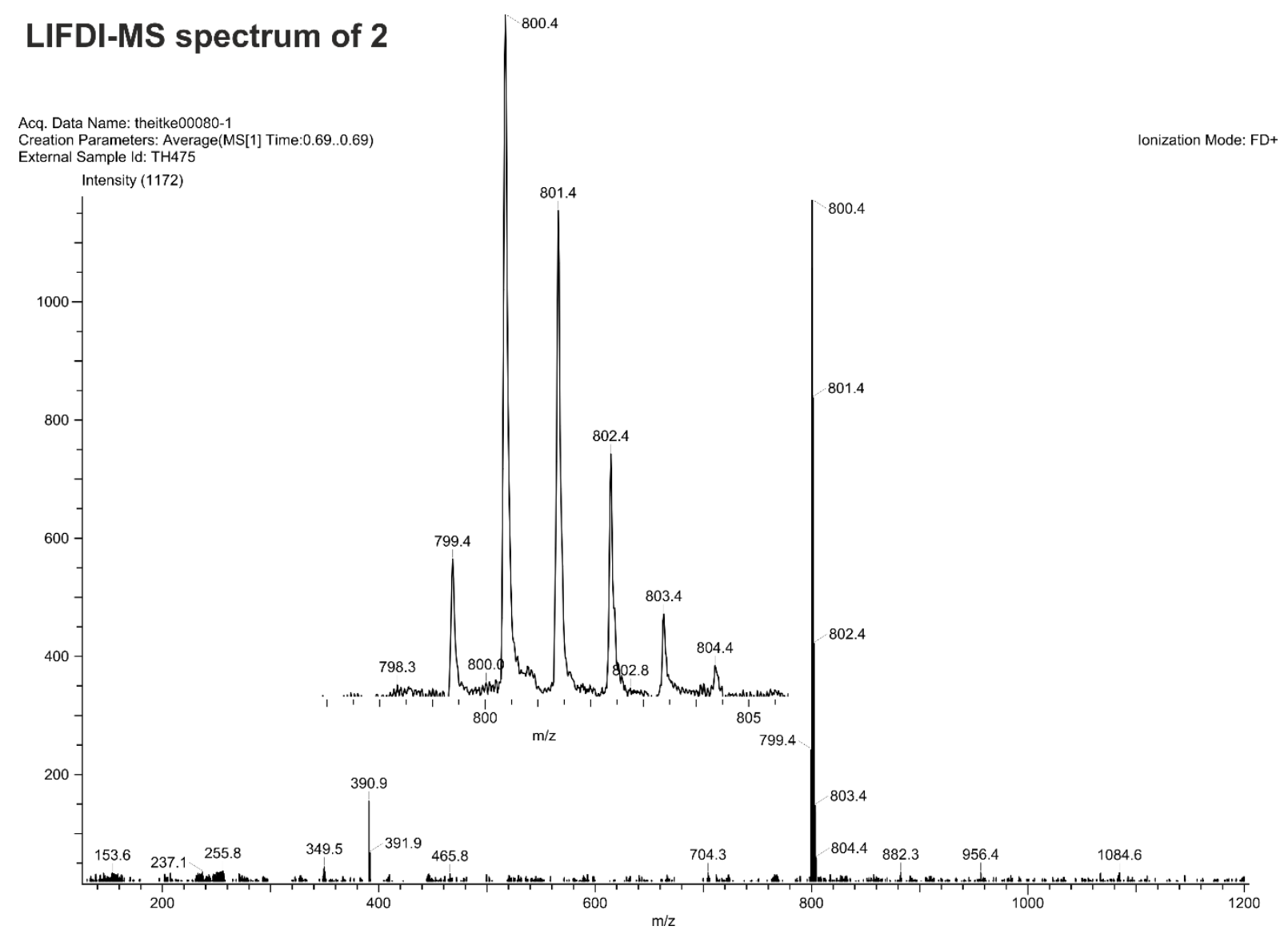




\section{Compound 3}

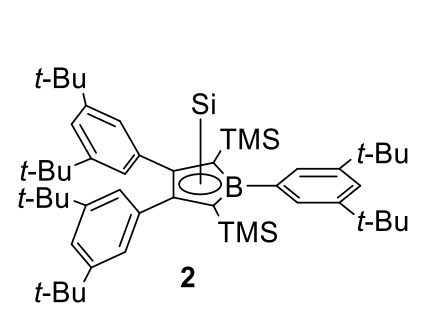

Molecular Weight: 801,2850

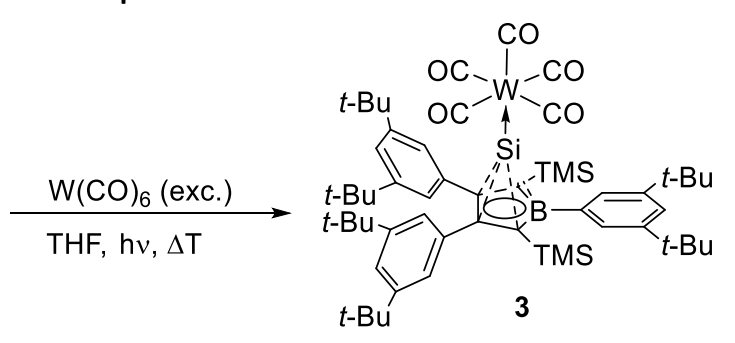

Molecular Weight: 1125,1750

In a glovebox, a schlenk flask (borosilicate glass) was loaded with $\mathrm{W}(\mathrm{CO})_{6}(51.4 \mathrm{mg}, 0.146 \mathrm{mmol}, 2 \mathrm{eq})$ and dry and degassed THF ( $2 \mathrm{~mL}$ ). The solution was irradiated outside of the glovebox with a mercury lamp for $3 \mathrm{~h}$ and afterwards compound 2 ( $58.5 \mathrm{mg}, 0.073 \mathrm{mmol}, 1 \mathrm{eq}$ ) was added as a solution in dry and degassed THF ( $1 \mathrm{~mL}$ ). The yellow solution was stirred at $60^{\circ} \mathrm{C}$ for 2 days and was then transferred to a quartz Schlenk ampoule. Irradiation of the solution with a mercury lamp was repeated for additional $3 \mathrm{~h}$ and the solution was afterwards again heated to $60^{\circ} \mathrm{C}$ overnight. During this time the colour of the solution changed from yellow to red. The solvent was then removed under reduced pressure and the Schlenk ampoule was transferred into a glovebox. The reddish-brown solid was extracted with cold hexane $\left(-40^{\circ} \mathrm{C}, 3 \times 0.5 \mathrm{~mL}\right)$ and the solvent of the extract was removed under reduced pressure. The resulting solid was again extracted with cold hexane $\left(-40{ }^{\circ} \mathrm{C}, 3 \times 0.5 \mathrm{~mL}\right)$ and after removal of the solvent under reduced pressure compound $3(79.7 \mathrm{mg}, 0.071 \mathrm{mmol}, 97 \%)$ was obtained as a reddish solid.

Crystals suitable for $\mathrm{x}$-ray crystallography were grown from a saturated hexane solution at $-40^{\circ} \mathrm{C}$.

Note: Half an equivalent of hexane was still present in the crystalline material, even after prolonged drying under reduced pressure. Since the NMR characterisation was done with crystals of compound 3 , the ${ }^{1} \mathrm{H}$ - and ${ }^{13} \mathrm{C}-\mathrm{NMR}$ showed signals corresponding to hexane. Elemental analysis was also performed with crystalline material.

\section{NMR:}

\section{Analytical Data for Compound 3}

${ }^{1} \mathrm{H}\left(500.25 \mathrm{MHz}, 298 \mathrm{~K}, \mathrm{C}_{6} \mathrm{D}_{6}, \mathrm{CD}_{5} \mathrm{H}\right.$ at $\left.7.15 \mathrm{ppm}\right): 7.77\left(\mathrm{~d},{ }^{4} J_{\mathrm{HH}}=1.9 \mathrm{~Hz}, 2 \mathrm{H}, o-H_{\text {ar } 1}\right), 7.59\left(\mathrm{t},{ }^{4} J_{\mathrm{HH}}=1.9 \mathrm{~Hz}, 1 \mathrm{H}, p-H_{\text {ar } 1}\right), 7.36(\mathrm{t}$, $\left.{ }^{4} J_{\mathrm{HH}}=1.8 \mathrm{~Hz}, 2 \mathrm{H}, p-H_{a r 3,4}\right), 7.35-7.29\left(\mathrm{br}, 2 \mathrm{H}, 0-H_{a r 3,4}\right), 1.47\left(\mathrm{~s}, 18 \mathrm{H}, \mathrm{Ar}_{1}-\mathrm{C}(M e)_{3}\right), 1.20-1.29\left(\mathrm{br}, 18 \mathrm{H}, \mathrm{Ar}_{3,4}-\mathrm{C}(M e)_{3}\right), 1.11-1.20$ (br, 18H, $\left.\operatorname{Ar}_{3,4}-\mathrm{C}(\mathrm{Me})_{3}\right), 0.09$ (s, 18H, Si $\left.(M e)_{3}\right)$.

One signal for the $o-H_{a r 3,4}$-protons is superimposed by the solvent signal.

${ }^{13} \mathrm{C}\left\{{ }^{1} \mathrm{H}\right\}\left(100.65 \mathrm{MHz}, 298 \mathrm{~K}, \mathrm{C}_{6} \mathrm{D}_{6}\right.$, solvent signal at $\left.128.0 \mathrm{ppm}\right): 194.5\left(\mathrm{CO}_{\mathrm{eq}},{ }^{1} \mathrm{JWW}_{\mathrm{CW}}=122.3 \mathrm{~Hz}\right), 193.1\left(\mathrm{CO}_{\mathrm{ax}},{ }^{1} \mathrm{~J}_{\mathrm{CW}}=148.0 \mathrm{~Hz}\right)$, 150.9 (br, $\left.m-C_{A r 3,4}\right), 149.7\left(m-C_{A r 1}\right), 140.1$ (borole- $C_{3,4}$ ), 139.6 (ipso- $C_{a r 1}$ ), 134.0 (ipso- $C_{a r 3,4}$ ), 128.7 (o-Car1), 126.3 (br, o- $C_{a r 3,4}$ ), 124.7 (br, o- $\left.C_{a r 3,4}\right), 122.3\left(p-C_{a r 3,4}\right), 121.2\left(p-C_{a r 1}\right), 113.0$ (borole- $\left.C_{2,5}\right), 35.1\left(\operatorname{Ar}_{1}-C\left(C_{3}\right)_{3}\right), 34.9\left(b r, A_{3,4}-C\left(\mathrm{CH}_{3}\right)_{3}\right), 31.8\left(\operatorname{Ar}_{1-}^{-}\right.$ $\left(\mathrm{C}\left(\mathrm{CH}_{3}\right)_{3}\right), 31.4\left(\mathrm{Ar}_{3,4}-\left(\mathrm{C}\left(\mathrm{CH}_{3}\right)_{3}\right), 1.8\left(\mathrm{Si}\left(\mathrm{CH}_{3}\right)_{3}\right)\right.$.

${ }^{11} \mathbf{B}\left(160.50 \mathrm{MHz}, 298 \mathrm{~K}, \mathrm{C}_{6} \mathrm{D}_{6}\right): 34.1\left(v_{1 / 2} \approx 1800 \mathrm{~Hz}\right)$.

${ }^{29} \mathrm{Si}\left(99.37 \mathrm{MHz}, 298 \mathrm{~K}, \mathrm{C}_{6} \mathrm{D}_{6}\right)$ : $-5.9\left(\mathrm{Si}(\mathrm{Me})_{3}\right),-254.76\left(\mathrm{Si}-\mathrm{W}(\mathrm{CO})_{5}\right.$, additional signal at -254.73 for ${ }^{10} \mathrm{~B}$ isotopologue, ${ }^{1} \mathrm{~W}_{\mathrm{W}-\mathrm{Si}}=$ $182 \mathrm{~Hz})$.

IR(ATR): selected bands: 2075 (m, CO), 1987 (w, CO), 1941 (s, CO), 1921 (s, CO)

Elemental Analysis: $\left(\mathrm{C}_{57} \mathrm{H}_{81} \mathrm{BO}_{5} \mathrm{Si}_{3} \mathrm{~W}\right) * 0.5\left(\mathrm{C}_{6} \mathrm{H}_{14}\right)$ calcd C 61.69, H 7.59; observed C 61.98, H 7.67.

LIFDI-MS: calcd exact mass: $1124.5 \mathrm{~m} / \mathrm{z}$; observed m/z: 1124.2 [M]+. 


\section{Preliminary crystal structure solution of Compound 3}

3 crystallised from hexane solutions in a freezer $\left(-40^{\circ} \mathrm{C}\right)$. The crystal crops were homogenous, however were not suitable for accountable scXRD data collection as they were very brittle and revealed poor crystallinity. A data set was collected and its structure was solved and refined. The preliminary solution and refinement confirms the connectivity pattern of the compound but the limited data quality does not allow for a discussion of bond distances. Due to the poor quality, the cif file was not submitted to the CCDC and details are listed here.

3: triclinic: $P-1, a=17.208(2) \AA, b=18.780(2) \AA, c=20.315(3) \AA \AA, \alpha=110.690(5)^{\circ}, \beta=92.017(6)^{\circ}, \gamma=91.918(5)^{\circ}, V=$ 6130.6(14) $\AA^{3}$;

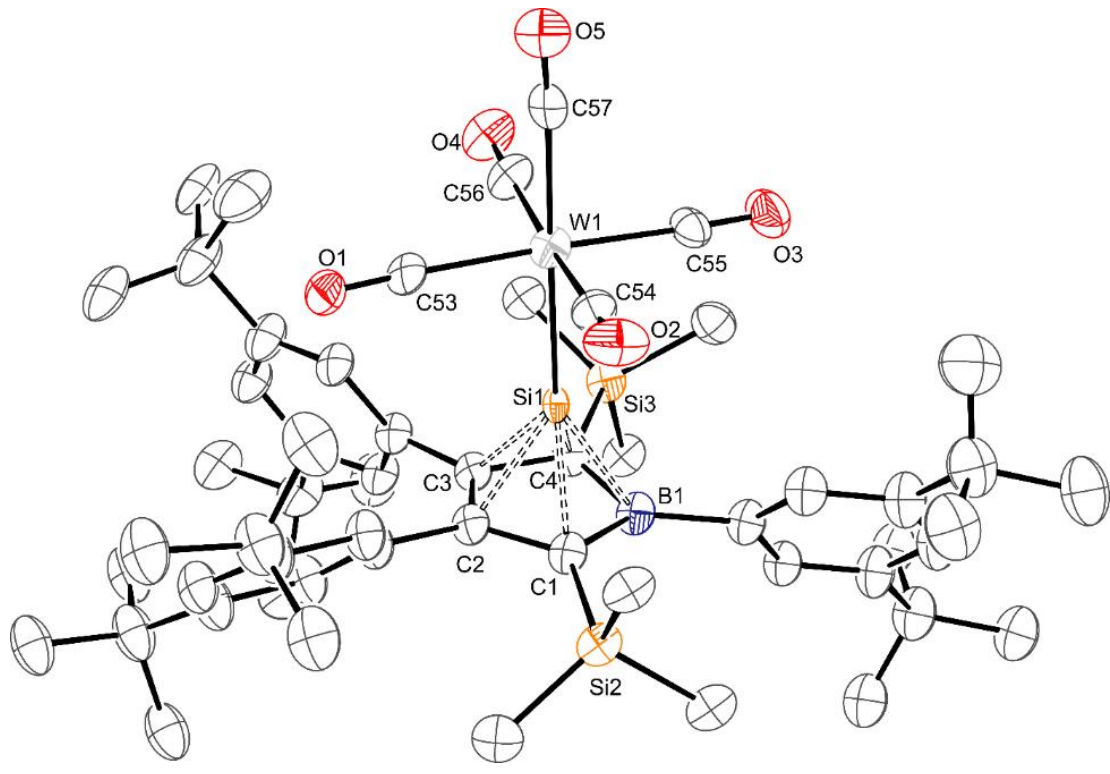

Figure S2: ORTEP plot of the molecular structure of $\mathbf{3}$ obtained from a preliminary solution and refinement of a poor dataset. Atomic displacement parameters are drawn at $50 \%$ probability level. Only one out of two independent molecules within the asymmetric unit is shown. Disorder in $t$ Bu groups and strongly hexane lattice molecules are omitted for the sake of clarity. $\mathrm{R}_{\text {Int }} 8.5 \%, R^{1}=21.4 \%, w R^{2}=47.23 \%$
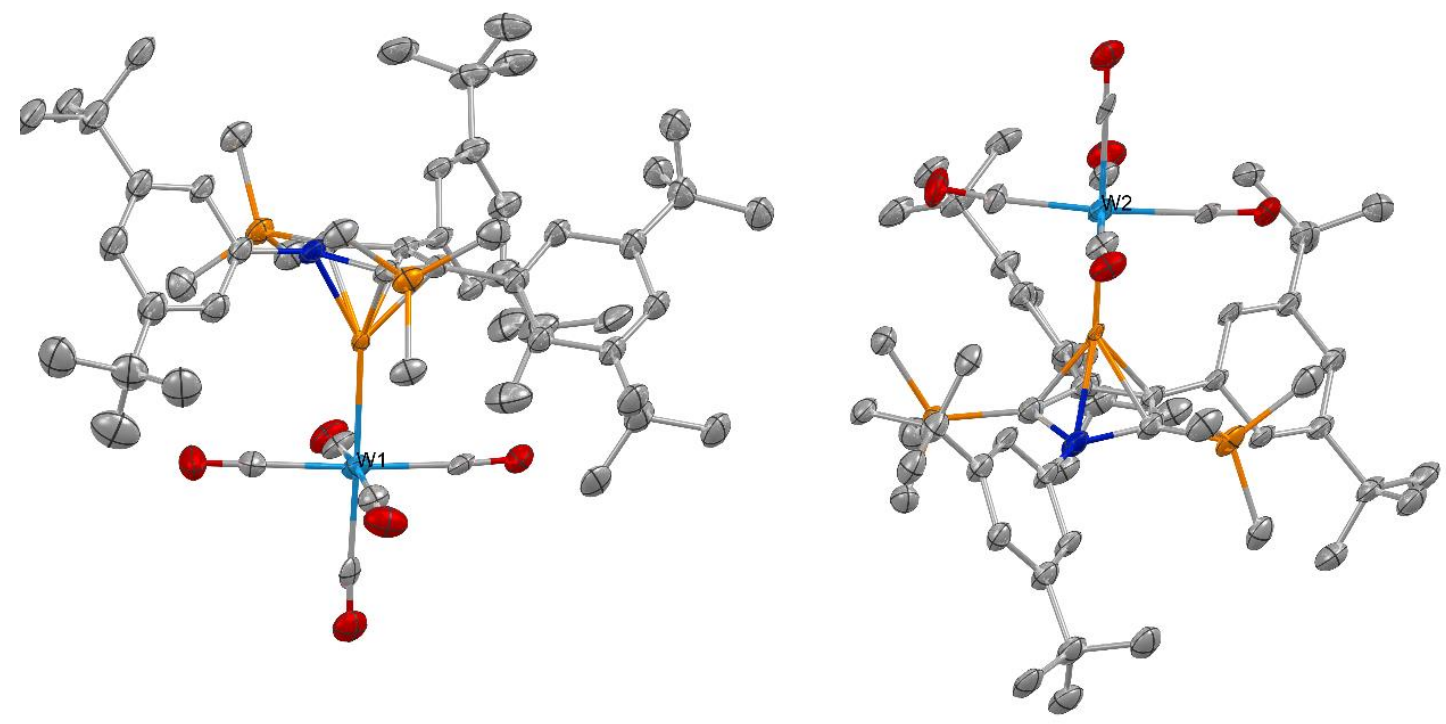

Figure S3: POVRAY depiction of both molecules in the asymmetric unit. 


\section{Spectra Plots for Compound 3}

1H-NMR-spectrum of $1-\left(3^{\prime}, 5^{\prime}-\mathrm{tBu} 2(\mathrm{C} 6 \mathrm{H} 3)\right)-2,5-(\mathrm{SiMe} 3) 2-3,4-\left(3^{\prime}, 5^{\prime}-\mathrm{tBu} 2(\mathrm{C} 6 \mathrm{H} 3)\right) 2-\mathrm{borole}$ * Si-W(CO) 5 in C6D6 \# referenced to $\mathrm{C} 6 \mathrm{D} 5 \mathrm{H}$ at $7.15 \mathrm{ppm}$

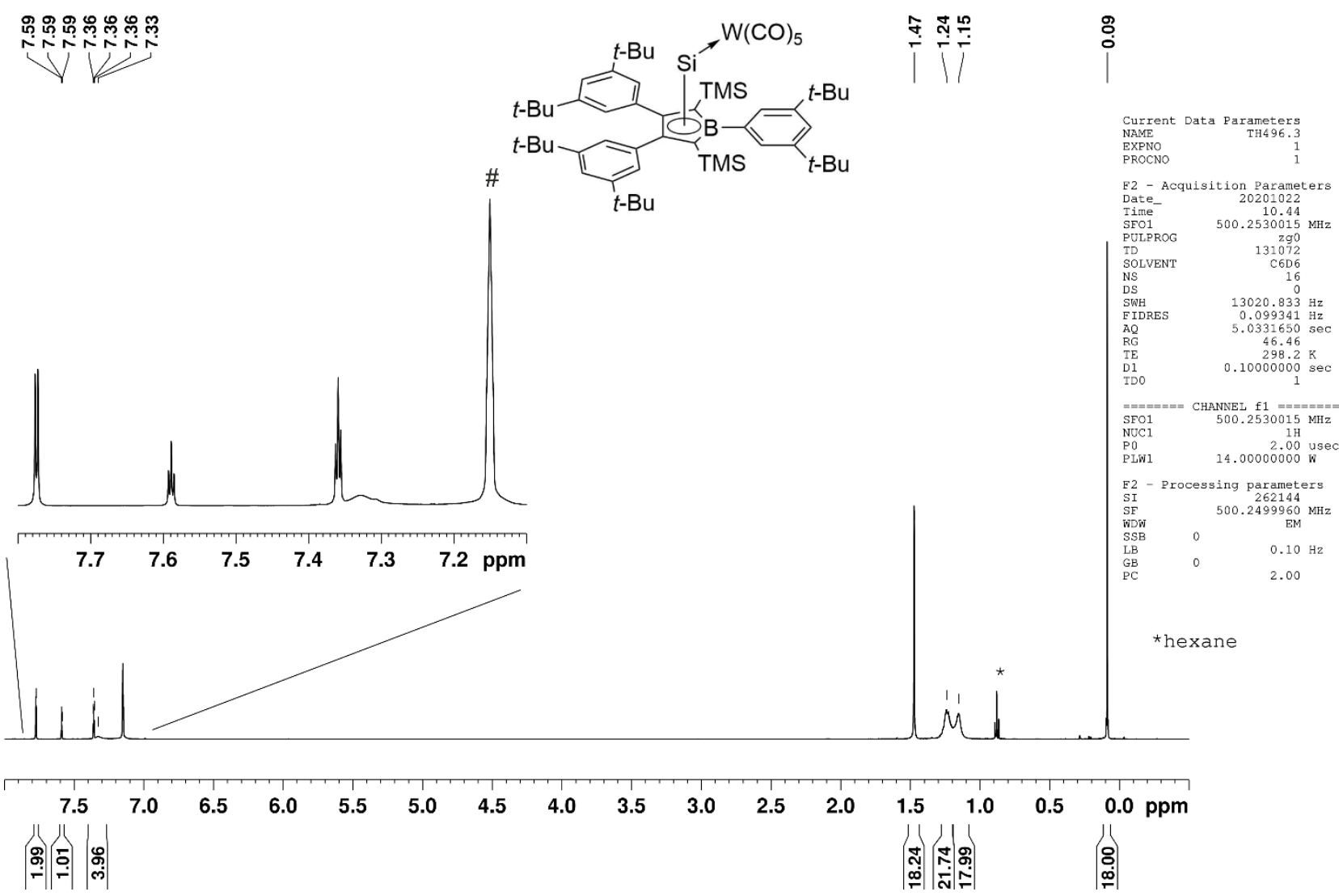

$13 \mathrm{C}\{1 \mathrm{H}\}-\mathrm{NMR}-$ spectrum of

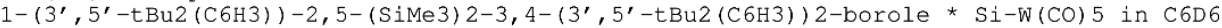
\# referenced to $C_{6} D_{6}$ at $128.0 \mathrm{ppm}$
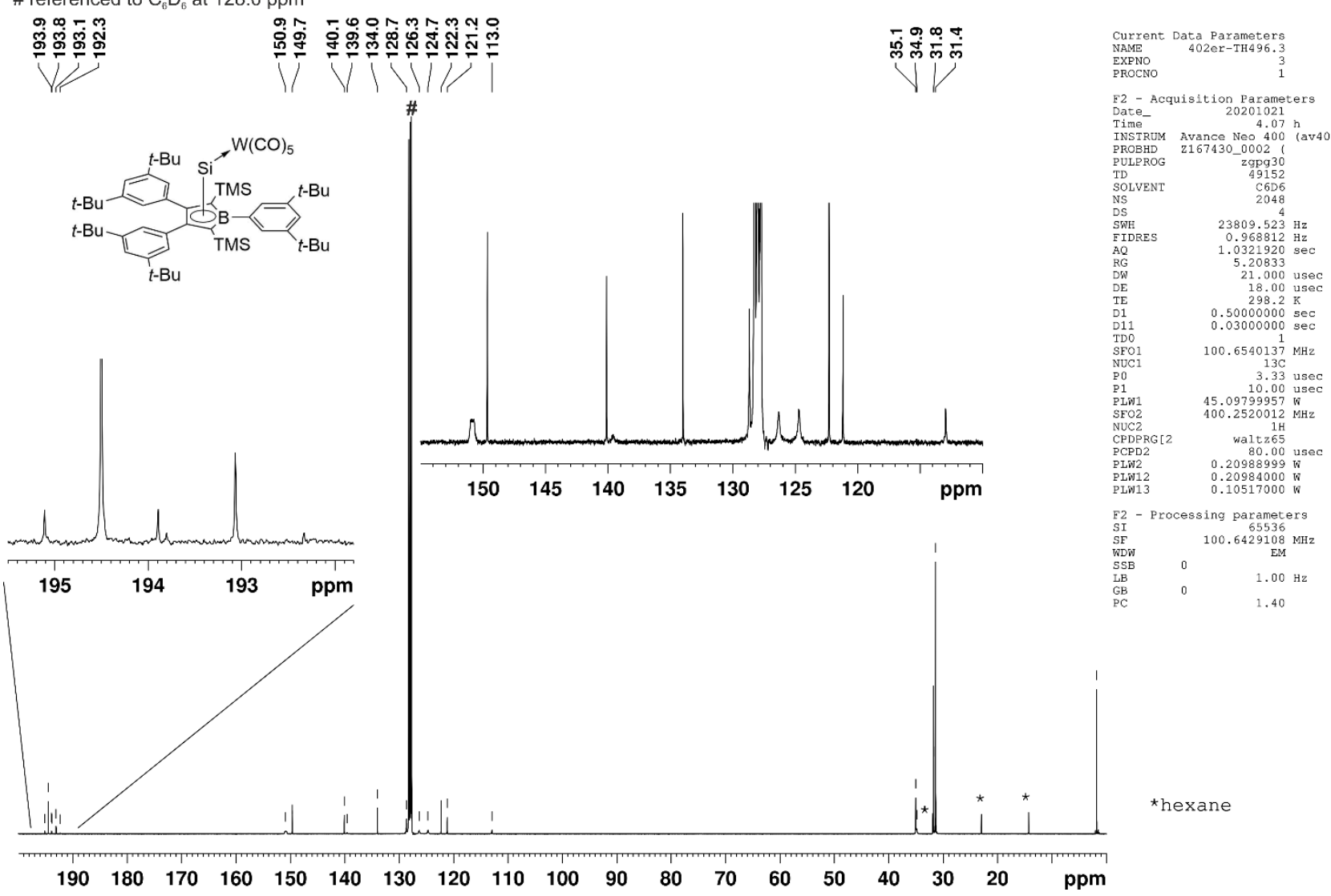
29Si-NMR-spectrum of

$1-\left(3^{\prime}, 5^{\prime}-\mathrm{tBu} 2(\mathrm{C} 6 \mathrm{H} 3)\right)-2,5-(\mathrm{SiMe} 3) 2-3,4-\left(3^{\prime}, 5^{\prime}-\mathrm{tBu} 2(\mathrm{C} 6 \mathrm{H} 3)\right) 2$-borole * Si-W (CO) 5 in C6D 6

:

\%R

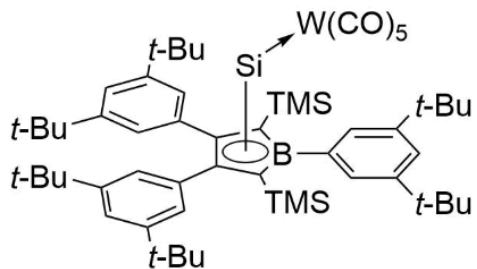

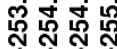

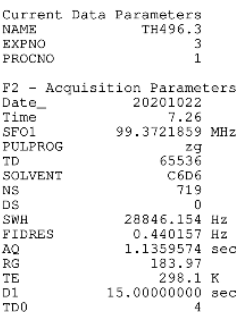

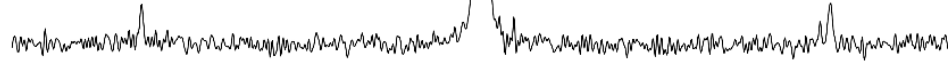
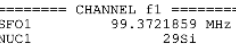
$\begin{array}{rl}11.30 & \text { us } \\ 70.00000000 & \mathrm{~W}\end{array}$

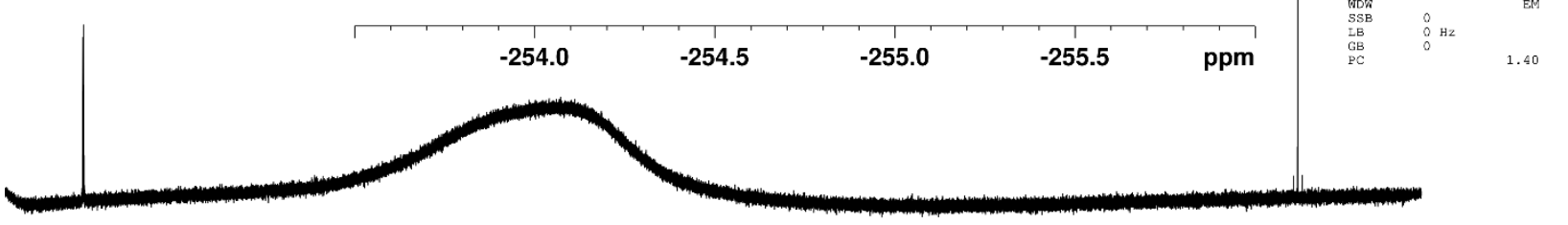

\begin{tabular}{|llllllllllllll|l}
\hline & -20 & -40 & -60 & -80 & -100 & -120 & -140 & -160 & -180 & -200 & -220 & -240 & -260 & ppm
\end{tabular}

11B-NMR spectrum (background suppressed) of

$1-\left(3^{\prime}, 5^{\prime}-\mathrm{tBu} 2(\mathrm{C} 6 \mathrm{H} 3)\right)-2,5-(\mathrm{SiMe} 3) 2-3,4-\left(3^{\prime}, 5^{\prime}-\mathrm{tBu} 2(\mathrm{C} 6 \mathrm{H} 3)\right) 2-$ borole * $\mathrm{Si}-\mathrm{W}(\mathrm{CO}) 5$ in $\mathrm{C} 6 \mathrm{D} 6$

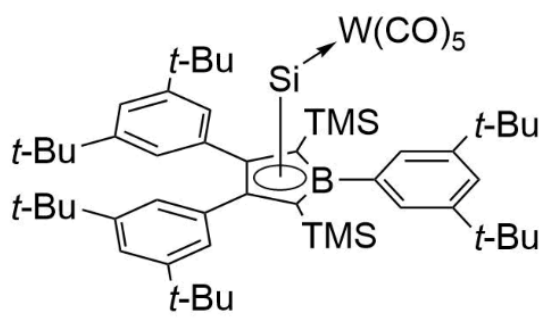

Current Data Parameters
TH496.3

EXPNO
PROCNO

F2 - Acquisition Parameters

Dime-

$\begin{array}{ll}10.46 \\ \text { SFO1 } & 160.5016850 \mathrm{MHz}\end{array}$

PULPROG zgbs

$\begin{array}{lr}\text { TD } & 1024 \\ \text { SOLVENT } & \text { C6D6 } \\ \text { NS } & 1024\end{array}$

$\begin{array}{ll}\text { DS } & 64 \\ \text { SWH } & 32051.281 \mathrm{~Hz} \\ \text { FIDRES } & 31.300079 \mathrm{~Hz}\end{array}$

$\begin{array}{ll}\text { FIDRES } & 31.300079 \mathrm{~Hz} \\ \mathrm{AQ} & 0.0159744 \mathrm{sec}\end{array}$

$\begin{array}{lr}\mathrm{AQ} & 183.97 \mathrm{~K} \\ \mathrm{RG} & 298.1 \mathrm{~K} \\ \mathrm{TE} & 0.50000000 \mathrm{se}\end{array}$

DO

$0.50000000 \mathrm{sec}$
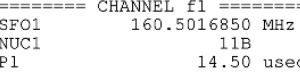

$\begin{array}{lr}\text { P1 } & 14.50 \text { usec } \\ \text { P2 } & 29.00 \text { usec }\end{array}$

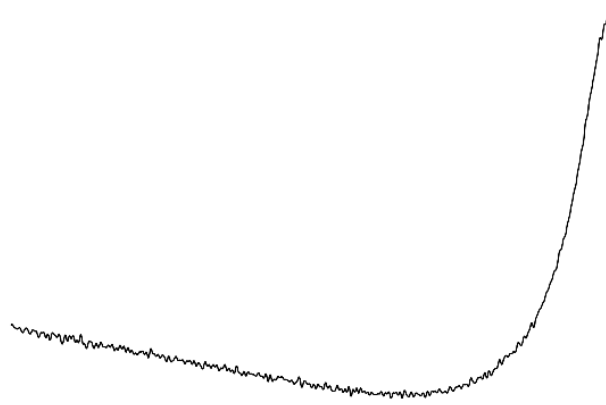

F2 - Processing parameters

$\begin{array}{ll}\text { SI } & 4096 \\ \text { SF } & 160.5000800 \mathrm{MHz}\end{array}$

$\begin{array}{ll}\text { SSB } & 0 \\ \text { LB } & 0 \mathrm{~Hz}\end{array}$

$\begin{array}{lll}\text { GB } & 0 & 1.40\end{array}$

$\begin{array}{lllllllllllllllllllll}100 & 90 & 80 & 70 & 60 & 50 & 40 & 30 & 20 & 10 & 0 & -10 & -20 & -30 & -40 & -50 & -60 & -70 & \mathrm{ppm}\end{array}$


IR Spectra of 3 (experimental and calculated)

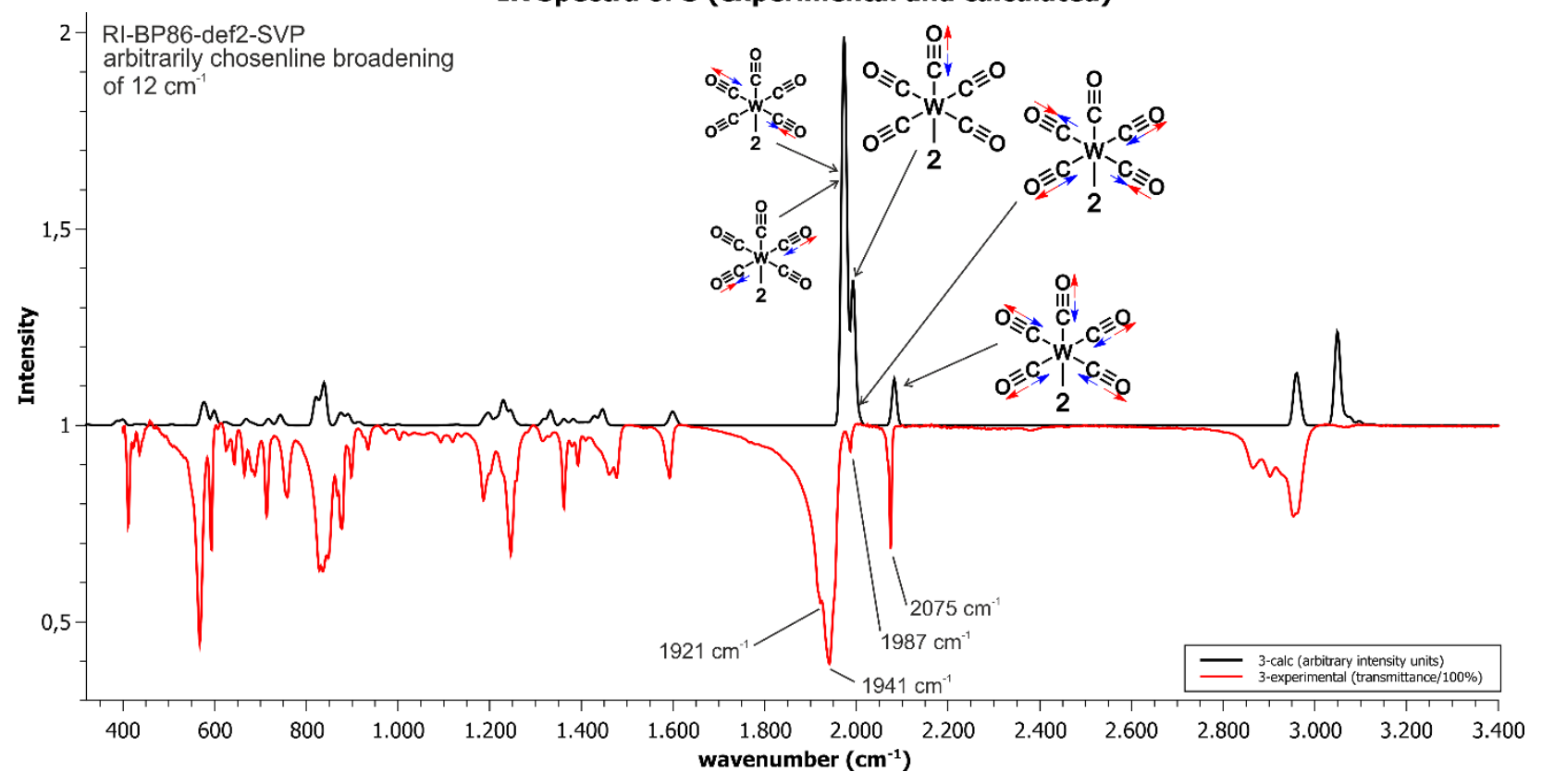

Figure S4: Experimental and calculated IR-spectra of 3.

\section{LIFDI-MS spectrum of 3}

Acq. Data Name: theitke00084-1

Creation Parameters: Average(MS[1] Time:0.63..0.69)

External Sample Id: TH496

Intensity (5361)
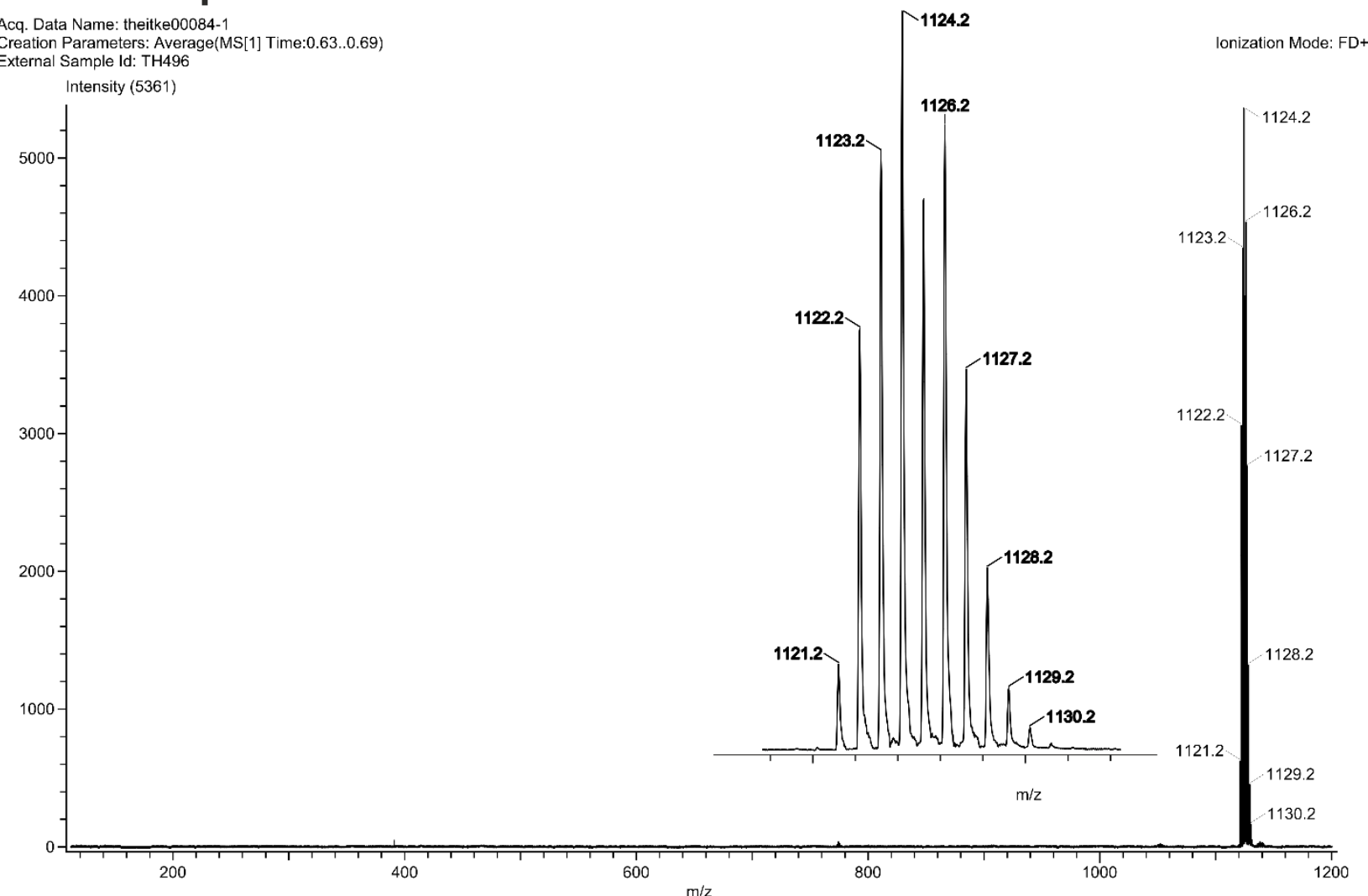


\section{Compound 4}

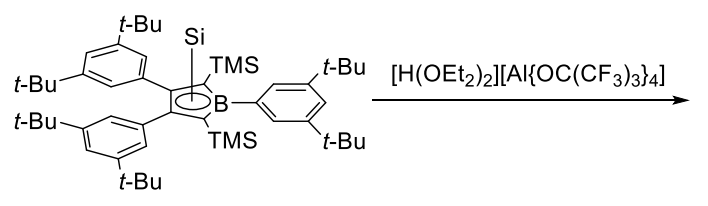

Molecular Weight: 801,2850

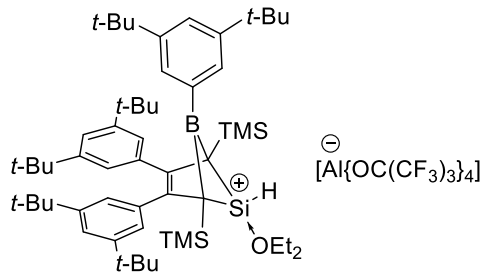

Molecular Weight: 1843,5121

In a glovebox, compound 2 (19.8 $\mathrm{mg}, 0.025 \mathrm{mmol}, 1 \mathrm{eq})$ was dissolved in $\mathrm{CD}_{2} \mathrm{Cl}_{2}(0.3 \mathrm{~mL})$ to yield a pale yellow solution. $\left[\mathrm{H}\left(\mathrm{OEt}_{2}\right)_{2}\right]\left[\mathrm{Al}\left\{\mathrm{OCC}\left(\mathrm{CF}_{3}\right)_{3}\right\}_{4}\right](27.6 \mathrm{mg}, 0.025 \mathrm{mmol}, 1 \mathrm{eq})$ was dissolved in a minimal amount of $\mathrm{CD}_{2} \mathrm{Cl}_{2}(0.4 \mathrm{~mL})$ and added with a syringe to the solution of compound $\mathbf{2}$ at ambient temperature. The faintly pink solution was transferred into a Young-type NMR tube and analyzed by multinuclear NMR spectroscopy at $-10^{\circ} \mathrm{C}$. It showed the consumption of approximately $80 \%$ of the starting material. Therefore additional $\left[\mathrm{H}\left(\mathrm{OEt}_{2}\right)_{2}\right]\left[\mathrm{Al}\left\{\mathrm{OC}\left(\mathrm{CF}_{3}\right)_{3}\right\}_{4}\right](6.1 \mathrm{mg}, 0.005 \mathrm{mmol}, 0.22 \mathrm{eq})$ was added to the reaction mixture. This time NMR analysis indicated full consumption of the starting material, showing relatively clean formation of compound 4, accompanied by the formation of an unknown side-product (ca. $10 \%$ ). The NMR tube was transferred back into a glovebox and the solvent was removed under reduced pressure to obtain a pale pink solid. This solid was dissolved in $\mathrm{CH}_{2} \mathrm{Cl}_{2}$ $(0.2 \mathrm{~mL})$ and stored at $-40^{\circ} \mathrm{C}$ overnight to yield a first crop of crystals, which were isolated by decanting of the mother liquor and were dried under reduced pressure. After a second crystallization step, compound 4 (19.4 mg, $0.011 \mathrm{~mol}, 44 \%)$ was obtained in a combined yield as a pale pink solid.

Crystals suitable for $\mathrm{x}$-ray crystallography were grown from a saturated dichloromethane solution at $-40{ }^{\circ} \mathrm{C}$.

Note: Crude reaction mixtures of 4 (ca $>90 \%$ ) slowly decompose in solution at ambient temperature over the course of several days and should be cooled. Solutions of isolated crystals of $\mathbf{4}$ were not found to decompose over a period of several days.

\section{NMR:}

\section{Analytical Data for Compound 4}

${ }^{1} \mathbf{H}\left(300.13 \mathrm{MHz}, 298 \mathrm{~K}, \mathrm{CD}_{2} \mathrm{Cl}_{2}, \mathrm{CDHCl}_{2}\right.$ at $\left.5.32 \mathrm{ppm}\right): 7.46\left(\mathrm{t},{ }^{4} \mathrm{~J}_{\mathrm{HH}}=1.8 \mathrm{~Hz}, 1 \mathrm{H}, p-H_{\text {ar, boron }}\right), 7.40\left(\mathrm{t},{ }^{4} \mathrm{~J}_{\mathrm{HH}}=1.7 \mathrm{~Hz}, 2 \mathrm{H}, p-H_{\text {ar } 2,3}\right)$, $7.26\left(\mathrm{~d},{ }^{4} \mathrm{~J}_{\mathrm{HH}}=1.8 \mathrm{~Hz}, 2 \mathrm{H}, o-H_{\text {ar, boron }}\right), 6.88\left(\mathrm{~d},{ }^{4} \mathrm{~J}_{\mathrm{HH}}=1.7 \mathrm{~Hz}, 4 \mathrm{H}, o-\mathrm{H}_{\text {ar } 2,3}\right), 5.46\left(\mathrm{~s},{ }^{1} \mathrm{JHSi}_{\mathrm{Hi}}=280.2 \mathrm{~Hz}, 1 \mathrm{H}, \mathrm{SiH}\right),, 4.60\left(\mathrm{q},{ }^{3} \mathrm{~J}_{\mathrm{HH}}=7.1\right.$ $\left.\mathrm{Hz}, 4 \mathrm{H}, \mathrm{O}\left(\mathrm{CH}_{2} \mathrm{CH}_{3}\right)_{2}\right), 1.69\left(\mathrm{t}, 3^{3} \mathrm{HH}_{3}=7.1 \mathrm{~Hz}, 6 \mathrm{H}, \mathrm{O}\left(\mathrm{CH}_{2} \mathrm{CH}_{3}\right)_{2}\right), 1.29\left(\mathrm{~s}, 18 \mathrm{H}, \operatorname{Ar}_{\text {boron }}-\mathrm{C}(M e)_{3}\right), 1.13\left(\mathrm{~s}, 36 \mathrm{H}, \mathrm{Ar}_{2,3}-\mathrm{C}(\mathrm{Me})_{3}\right),-0.03(\mathrm{~s}$, $\left.18 \mathrm{H}, \mathrm{Si}(\mathrm{Me})_{3}\right)$. Additional OEt 2 species: $4.68\left(\mathrm{q},{ }^{3} \mathrm{~J}_{\mathrm{HH}}=7.1 \mathrm{~Hz}, 4 \mathrm{H}, \mathrm{O}\left(\mathrm{CH}_{2} \mathrm{CH}_{3}\right)_{2}\right), 1.68\left(\mathrm{t}, 3^{3} \mathrm{HH}=7.1 \mathrm{~Hz}, 6 \mathrm{H}, \mathrm{O}\left(\mathrm{CH}_{2} \mathrm{CH}_{3}\right)_{2}\right)$.

${ }^{13} \mathrm{C}\left\{{ }^{1} \mathrm{H}\right\}\left(100.65 \mathrm{MHz}, 298 \mathrm{~K}, \mathrm{C}_{2} \mathrm{DCl}_{2}\right.$, solvent signal at $\left.53.84 \mathrm{ppm}\right): 151.8\left(m-C_{A r 2,3}\right), 150.8\left(m-C_{A r, b o r o n}\right), 132.2\left(\right.$ ipso- $\left.C_{\text {ar2,3 }}\right), 130.3$ (o- $\left.C_{a r, b o r o n}\right), 125.6\left(C_{2,3}\right), 124.0\left(p-C_{a r, b o r o n}+p-C_{a r 2,3}\right), 123.8\left(o-C_{a r 2,3}\right), 121.7\left(q,{ }^{1} \mathrm{CF}_{1}=292.0 \mathrm{~Hz}, \mathrm{CF}_{3}\right), 75.6\left(\mathrm{O}_{(}\left(\mathrm{CH}_{2} \mathrm{CH}_{3}\right)_{2}\right), 62.8\left(C_{1,4}\right)$,

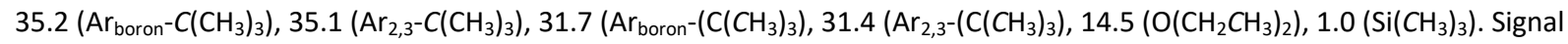

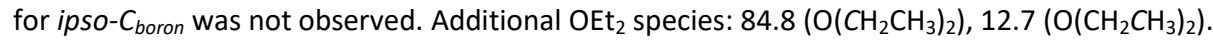

Note: A very broad signal likely stemming from the quaternary carbon atom of $\left[\mathrm{Al}\left\{\mathrm{OC}\left(\mathrm{CF}_{3}\right)_{3}\right\}_{4}\right]^{-}$was observed in concentrate crude reaction mixture in $\mathrm{CD}_{2} \mathrm{Cl}_{2}$ at $-10^{\circ} \mathrm{C}$ at $78.9 \mathrm{ppm}$. The spectra of 4 obtained from crude reaction mixtures or isolated crystalline material contained, in varying amounts, signal sets of a further species containing OEt groups. This second species does not belong to or interact with $\mathbf{4}$ and its presence in varying amounts does not affect the signal sets of $\mathbf{4}$.

${ }^{11} \mathbf{B}\left(160.50 \mathrm{MHz}, 263 \mathrm{~K}, \mathrm{CD}_{2} \mathrm{Cl}_{2}\right):-32.4\left(v_{1 / 2} \approx 500 \mathrm{~Hz}\right)$.

${ }^{19} \mathrm{~F}\left\{{ }^{1} \mathrm{H}\right\}\left(282.37 \mathrm{MHz}, 298 \mathrm{~K}, \mathrm{CD}_{2} \mathrm{Cl}_{2}\right):-75.7$.

${ }^{29} \mathrm{Si}\left(99.38 \mathrm{MHz}, 263 \mathrm{~K}, \mathrm{CD}_{2} \mathrm{Cl}_{2}\right):-5.6\left(\mathrm{Si}(\mathrm{Me})_{3}\right),-16.9\left(\mathrm{~d},{ }^{1} \mathrm{~J}_{\mathrm{SiH}}=280.2 \mathrm{~Hz}, \mathrm{H}\right)$.

Elemental Analysis: no satisfactory elemental analysis was obtained likely due to reactivity of the sample and the perfluorinated counteranion

LIFDI-MS: the $[\mathrm{M}]^{+}$signal was not observed. Instead we detected species that are likely formed by abstraction of a $\mathrm{OC}\left(\mathrm{CF}_{3}\right)_{3}$ group that stems from decomposition of the counteranion. 
1H-NMR-spectrum of compound 4 in $\mathrm{CD} 2 \mathrm{Cl} 2$

\# referenced to $\mathrm{CDHCl}_{2}$ at $5.32 \mathrm{ppm}$

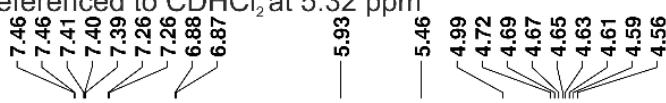

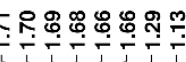

$\stackrel{\substack{0 \\ i}}{i}$

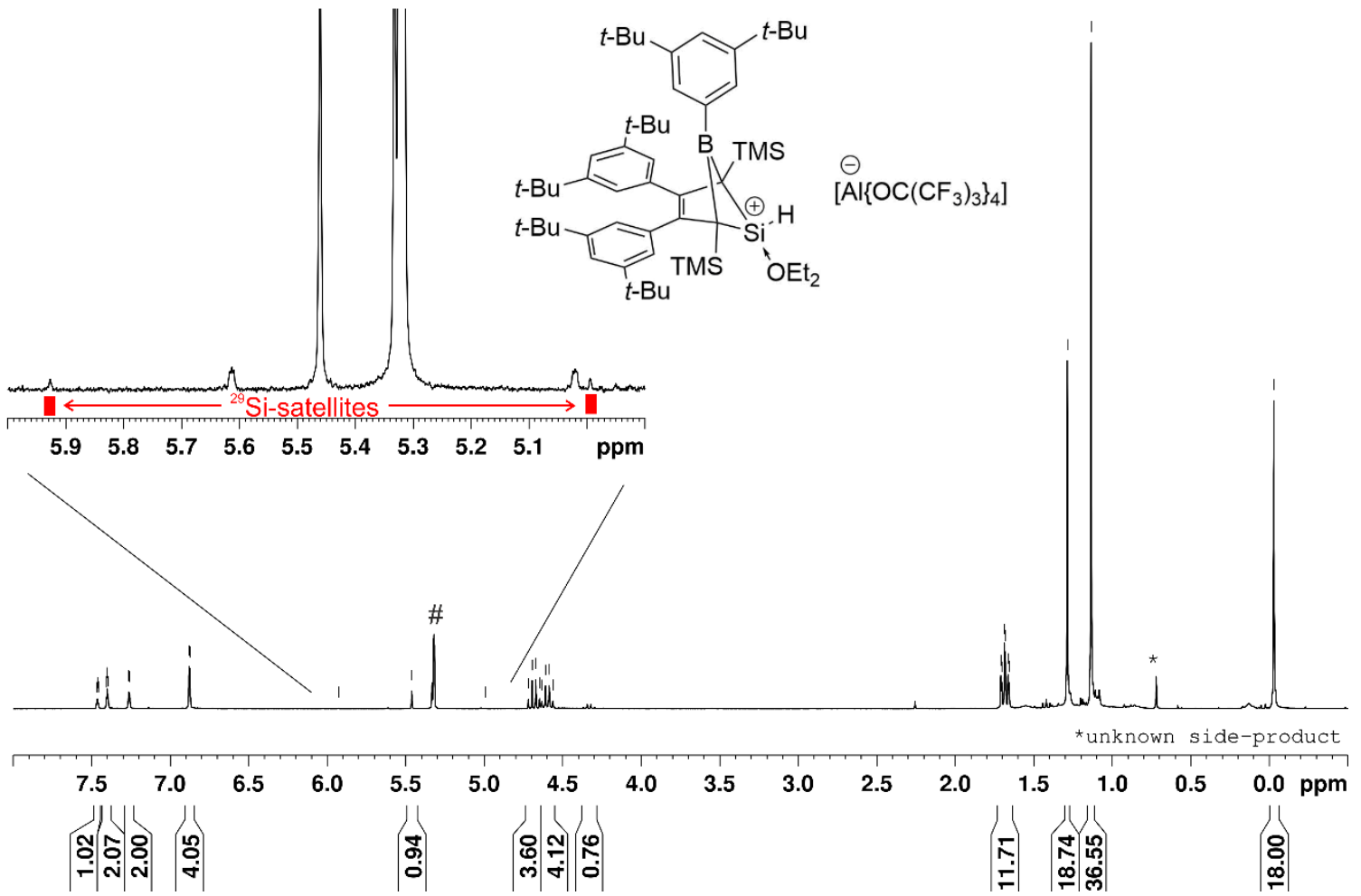

$13 \mathrm{C}\{1 \mathrm{H}\}-\mathrm{NMR}-$ spectrum of compound 4 in $\mathrm{CD} 2 \mathrm{Cl} 2$

\#referenced to CD2Cl2 at $53.8 \mathrm{ppm}$

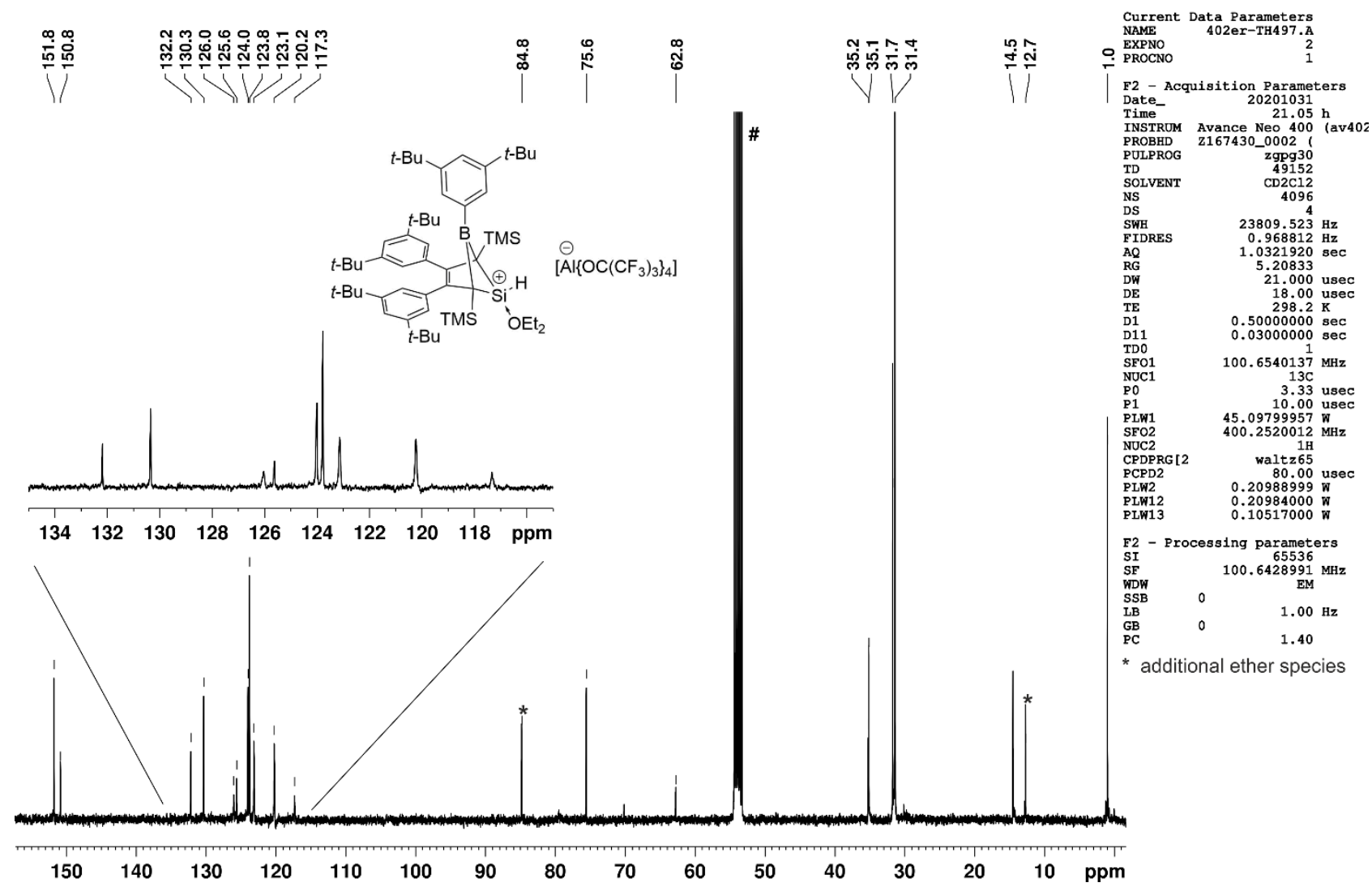


29Si-NMR-spectrum of compound 4 in CD2Cl2

including proton-coupling

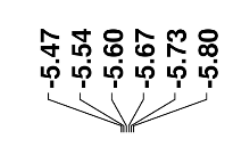

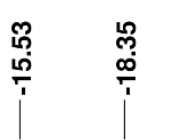

$\begin{array}{lr}\text { Current Data Parameters } \\ \text { NAME } & \text { TH497.2 } \\ \text { EXPNO } & 3 \\ \text { PROCNO } & 1\end{array}$

F2 - Acquisition Parameters

Date__ 20201015

$\begin{array}{ll}\text { Time } & 12.02 \\ \text { SFO1 } & 99.3856030 \mathrm{MHz}\end{array}$

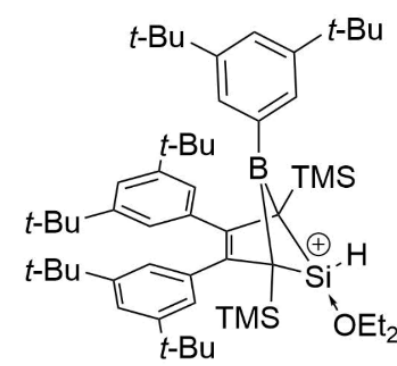

$\left.\stackrel{\ominus}{\ominus} \mathrm{Al}\left\{\mathrm{OCC}\left(\mathrm{CF}_{3}\right)_{3}\right\}_{4}\right]$

PULPROG

SOLVENT

SOL
DS
SS

SWH

FIDRES $\quad 19841.270 \mathrm{~Hz}$

$\mathrm{AQ} \quad 1.6515073 \mathrm{sec}$

RG $\quad 183.97$

D1 $\quad 15.00000000 \mathrm{sec}$

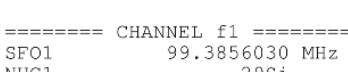

NUC1

PLW1

11.30 usec

F2 - Processing parameters

SI 131072

$\begin{array}{ll}\text { SE } & 99.3856030 \mathrm{MH}\end{array}$

$\begin{array}{lll}\text { SSB } & 0 & 3.00 \mathrm{~Hz}\end{array}$

$\begin{array}{lll}\mathrm{GB} & 0 & 1.40\end{array}$

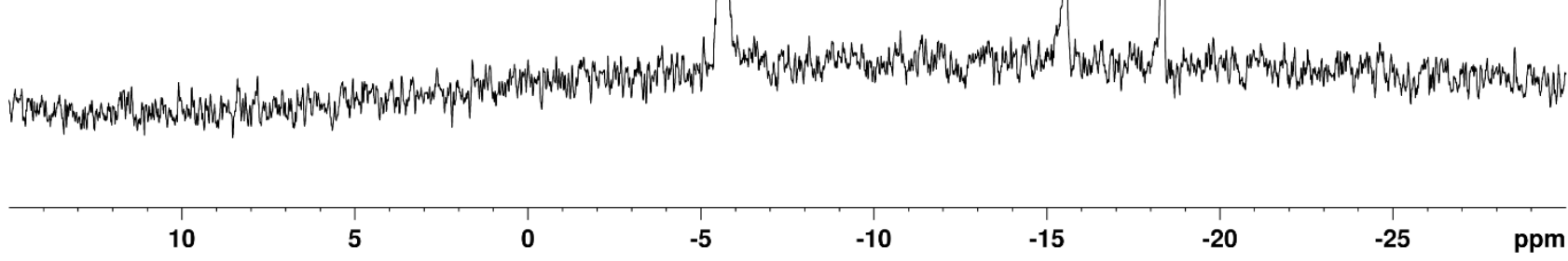

11B-NMR spectrum (background suppressed) of compound 4 in $\mathrm{CD} 2 \mathrm{Cl} 2$

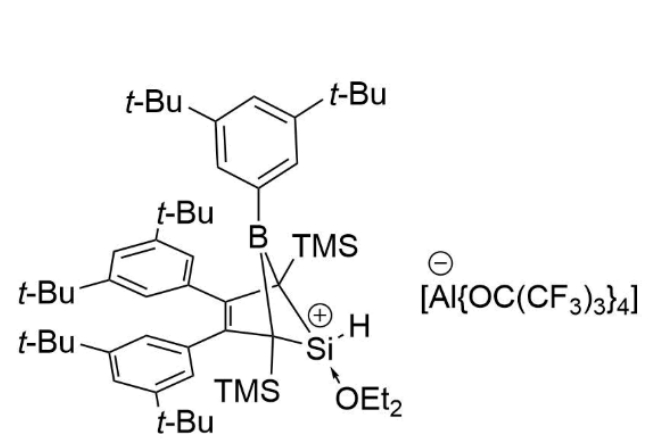

$\begin{array}{lllllllllllllllllll}100 & 90 & 80 & 70 & 60 & 50 & 40 & 30 & 20 & 10 & 0 & -10 & -20 & -30 & -40 & -50 & -60 & -70 & \text { ppm }\end{array}$ 

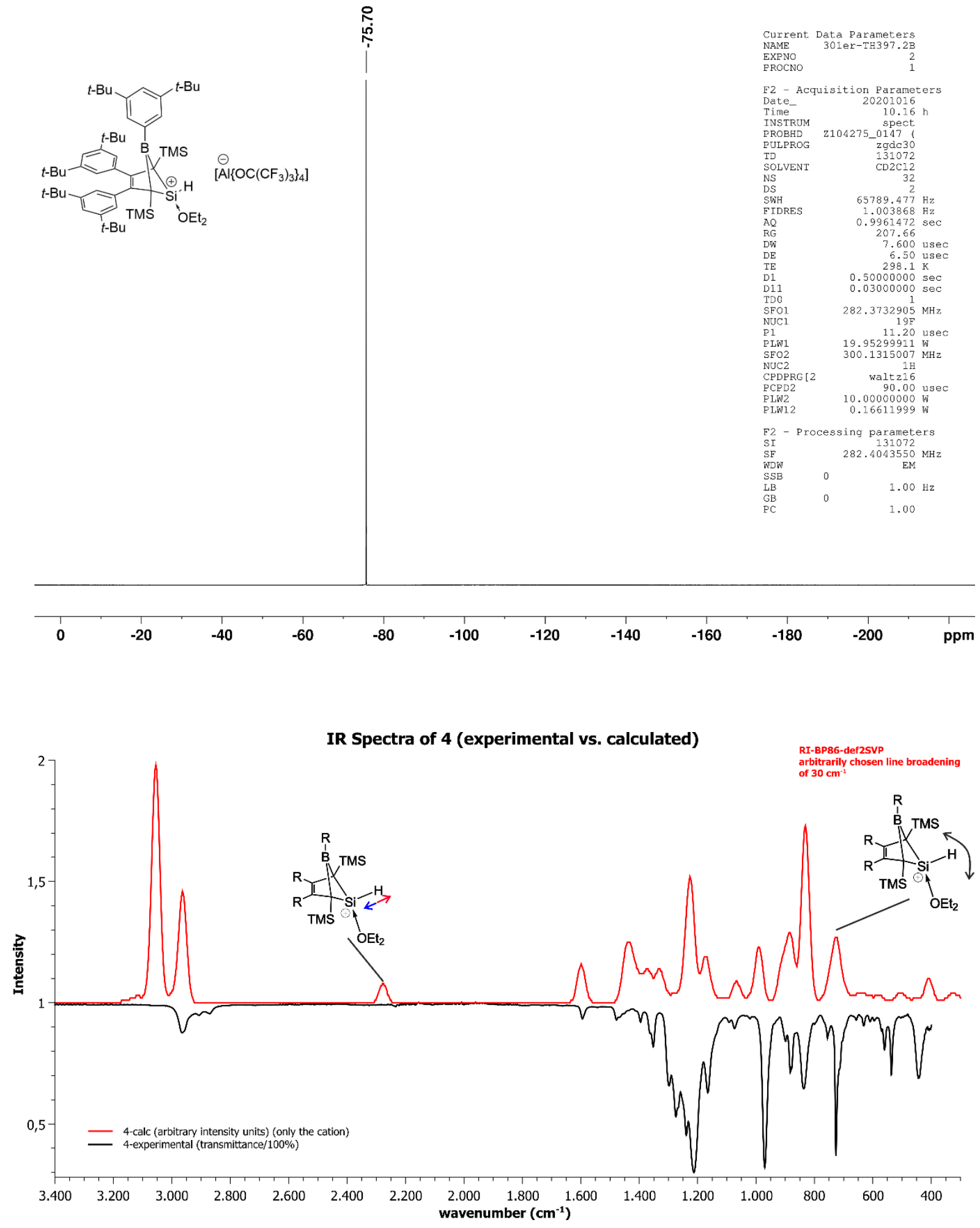

Figure S5: Experimental and calculated IR-spectra of 4. 
Details of the crude reaction mixture $2+1.2$ equiv. $\left[\mathrm{H}\left(\mathrm{Et}_{2} \mathrm{O}\right)_{2}\right]\left[\mathrm{Al}\left\{\mathrm{OCC}\left(\mathrm{CF}_{3}\right)_{3}\right\}_{4}\right]$ to form 4 in $\mathrm{CD}_{2} \mathrm{Cl}_{2}$ at $-10^{\circ} \mathrm{C}$ (scaled to allow identification of low-intensity signals) $\mathrm{H}-\mathrm{NMR}$ spectrum referenced to $\mathrm{CDHCl}_{2}$ at $5.32 \mathrm{ppm}$

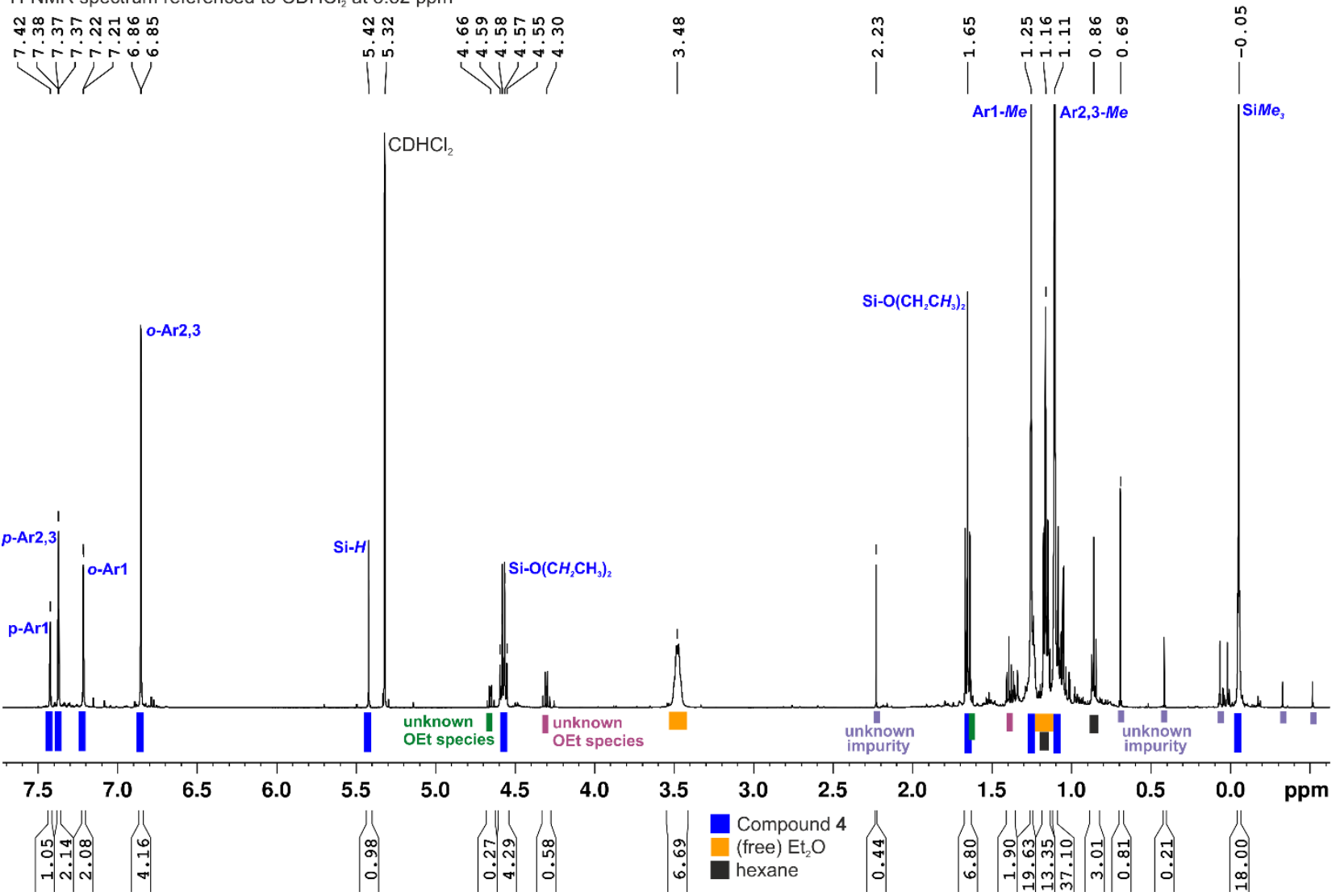

Details of the crude reaction mixture $2+1.2$ equiv. $\left[\mathrm{H}\left(\mathrm{Et}_{2} \mathrm{O}\right)_{2}\right]\left[\mathrm{Al}\left\{\mathrm{OOC}\left(\mathrm{CF}_{3}\right)_{3}\right\}_{4}\right]$ to form 4 in $\mathrm{CD}_{2} \mathrm{Cl}_{2}$ at $-10^{\circ} \mathrm{C}$ (scaled to allow identification of low-intensity signals) ${ }^{13} \mathrm{C}-\mathrm{NMR}$ spectrum referenced to $\mathrm{CD}_{2} \mathrm{Cl}_{2}$ at $53.8 \mathrm{ppm}$

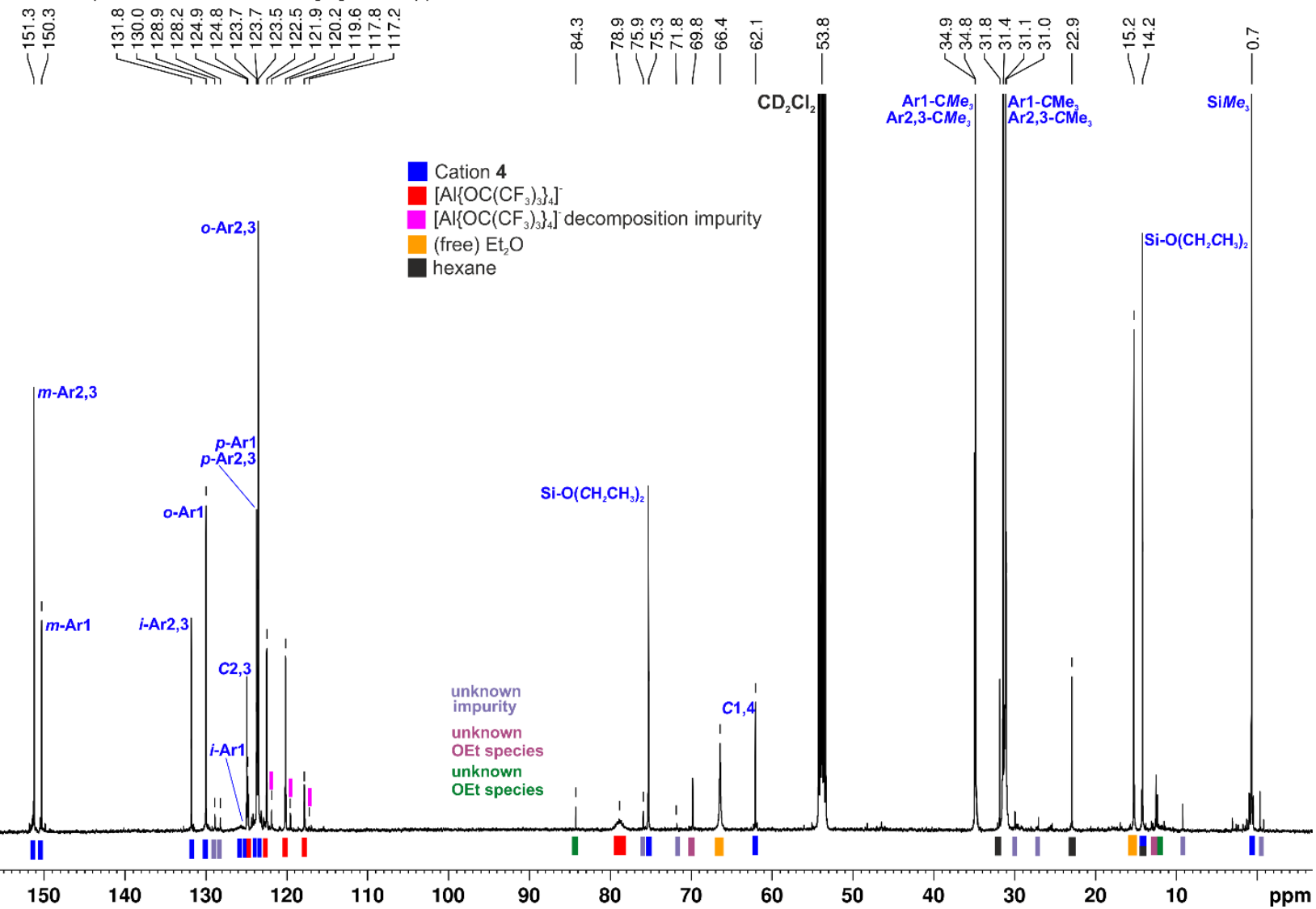




\section{Crystallographic Details}

General Data Acquisition and Processing

X-ray data for 1, 2, 3 and $\mathbf{4}$ were collected on Bruker APEX II CCD diffractometers with Mo Ka radiation. The data were integrated using SAINT implemented in Bruker's APEX3 programme suite. ${ }^{[9]}$ The data obtained for $\mathbf{3}$ was too poor to extract more data than the connectivity pattern. SADABS was used for multi-scan absorption correction. ${ }^{[10]}$ Structure solution was performed with SHELXT ${ }^{[11]}$ and refined using SHELXL ${ }^{[12]}$ along the graphical user interphase of ShelXle. ${ }^{[13]}$ In some cases DSR has been applied to treat disordered solvent molecules. ${ }^{[14]}$ All hydrogen atoms were placed with a riding model except for Si$\mathrm{H}$ in $\mathbf{4}$ which was found and freely refined. Further details on the individual data sets are tabulated in the analytical section of each compound.

\section{Crystallographic and Refinement Details 1}

Colorless crystals were found to be suitable for $\mathrm{x}$-ray diffraction. One ${ }^{\mathrm{t}} \mathrm{Bu}$ group was found to be disordered and modeled over two positions using SAME, SIMU and RIGU commands.

\section{Crystallographic and Refinement Details 2}

Colorless crystals were sensitive to air and moisture and were picked under a continuous stream of cold nitrogen $\left(-100^{\circ} \mathrm{C}\right)$. The crystal chosen for data collection only diffracted weakly at higher resolutions $(<0.82 \AA)$. The asymmetric unit (depicted) contained three full molecules of $\mathbf{2}$ with one or two ${ }^{t} \mathrm{Bu}$ groups of each molecule being disordered over two positions. The disorder was modelled accordingly using SAME, SIMU and RIGU commands. A disorder of the apical Si atom was found and modelled for two of the molecules were the Si atom partially (ca. 10-15\%) occupies the opposite site of the borole plane. A hexane molecule is found to occupy a solvent accessible tunnel and was modelled as one molecule of hexane to be disordered over three positions. The hexane molecules were modelled using the DSR tool, SAME, SIMU and RIGU and the contributions combined by SUMP command to an occupation of one full molecule.

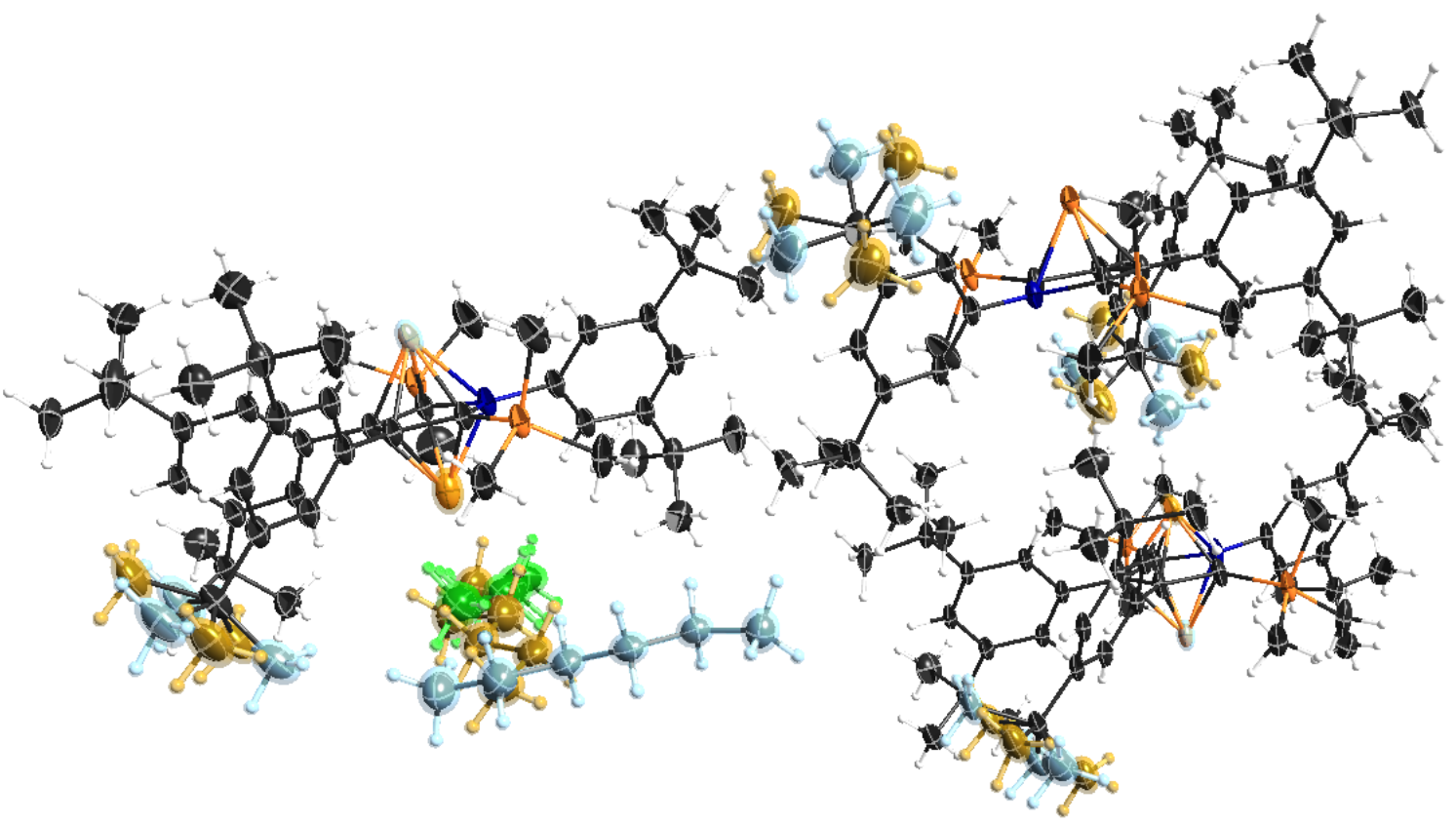

Figure S6: Depiction of the asymmetric unit of $\mathbf{2}$ including the modelled disorder (PART1 blue, PART 2 orange, PART 3 green). 


\section{Crystallographic and Refinement Details 3}

Several examined crops of colorless crystals were of repeatedly low crystallinity and the diffraction patterns from at least one direction indicated poor ordering. Even when small crystals fragments were examined, the pattern contained reflections likely stemming from further domains. For the examined crystal specimen, a unit cell was found for a majority of reflections and data processing was possible allowing structure solution and refinement and thus the identification of the connectivity pattern. However, the data and refinement statistics do not allow quantitative evaluation of the dataset and contained . Attempts to process the data considering twinning were unsuccessful. Depictions of the preliminary structure solution are given in the respective analytical section of compound $\mathbf{3}$.

The unit cell found and used for data processing is:

triclinic: $P-1, a=17.208(2) \AA, b=18.780(2) \AA, c=20.315(3) \AA, \alpha=110.690(5)^{\circ}, \beta=92.017(6)^{\circ}, \nu=91.918(5)^{\circ}, V=6130.6(14) \AA^{3}$;

\section{Crystallographic and Refinement Details 4}

Crystals were grown from cold $\left(-40^{\circ} \mathrm{C}\right)$ solutions in dichlormethane and crystals rapidly dissolved upon gentle warming of these solutions. A crystal crop for examination was carefully taken and kept cool until the colorless crystals were picked rapidly under a continuous stream of cold nitrogen $\left(-100^{\circ} \mathrm{C}\right)$. At ambient temperature the crystals rapidly showed signs of decomposition and loss of crystallinity. The asymmetric unit (depicted) contained two independent ion pairs and four molecules of dichoromethane. One of the perfluorinated tert.-butoxyaluminate anions was found to be entirely severely disordered and this disordered was modelled over two positions making use of the DSR tool and SAME, SIMU and RIGU commands. Further minor residual density may stem from further disorder of one of the $\mathrm{OC}\left(\mathrm{CF}_{3}\right)_{3}$ groups. Two of the dichloromethane molecules and some ${ }^{\mathrm{t}} \mathrm{Bu}$-groups were found to be disordered and each modelled over two positions. The $\mathrm{H}$-atoms at each Si-atom in the bicyclic moiety were found in the density map and refined freely.

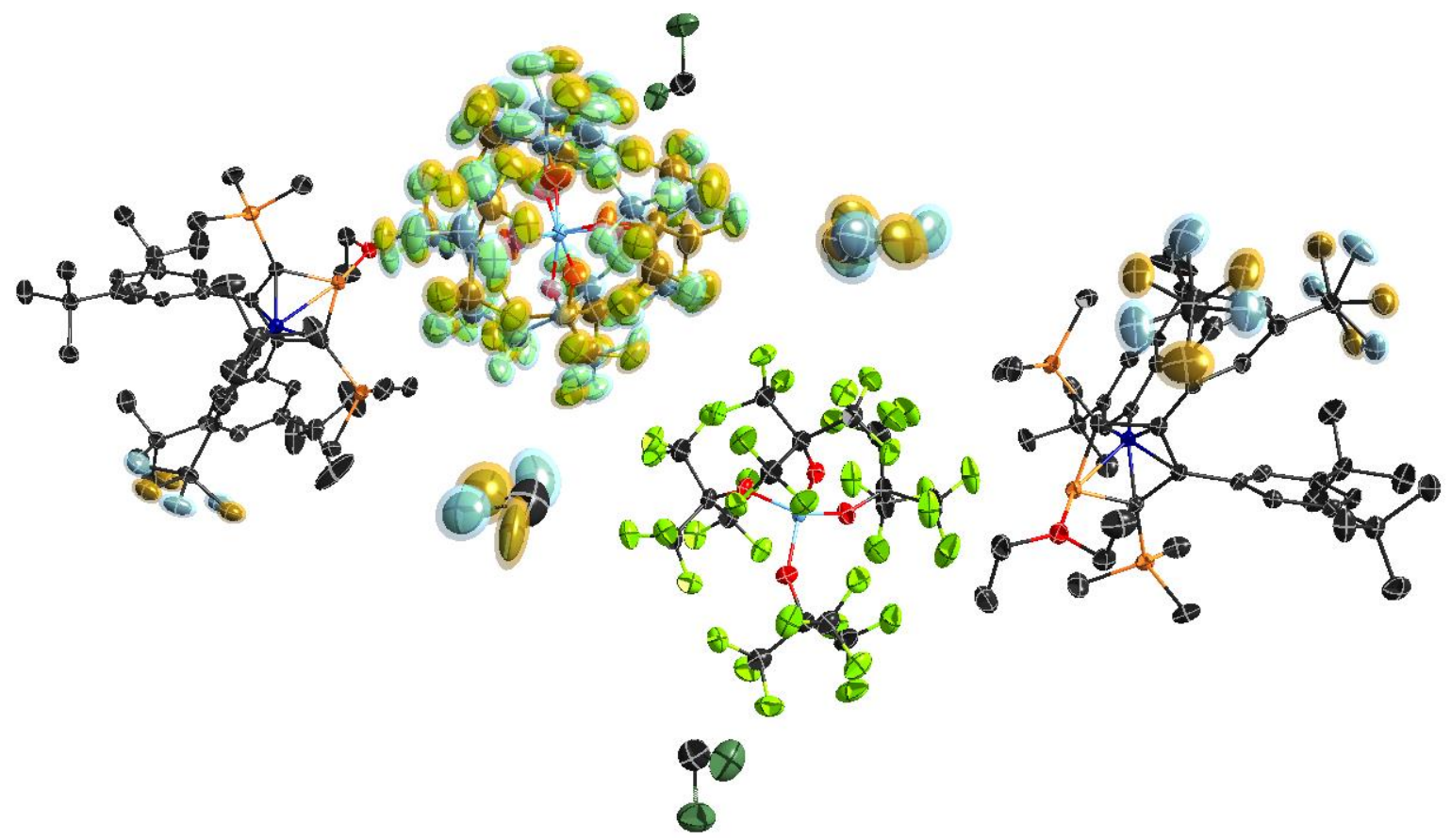

Figure S7: Depiction of the asymmetric unit of $\mathbf{4}$ (hydrogen atoms omitted) including the modelled disorder (PART1 blue, PART 2 orange). 
Tabulated Crystallographic Details 1,2 and 4

\begin{tabular}{|c|c|c|c|}
\hline & 1 & $2 \times 0.33\left(\mathrm{C}_{6} \mathrm{H}_{14}\right)$ & $4 \times 2\left(\mathrm{CH}_{2} \mathrm{Cl}_{2}\right)$ \\
\hline CCDC number & 2044043 & 2044044 & 2044045 \\
\hline empirical formula & $\mathrm{C}_{60} \mathrm{H}_{101} \mathrm{Si}_{2} \mathrm{O}_{2} \mathrm{BLi}_{2}$ & $\mathrm{C}_{162} \mathrm{H}_{257} \mathrm{~B}_{3} \mathrm{Si}_{9}$ & $\mathrm{C}_{148} \mathrm{H}_{192} \mathrm{~B}_{2} \mathrm{Si}_{6} \mathrm{Al}_{2} \mathrm{O}_{10} \mathrm{~F}_{72} \mathrm{Cl}_{8}$ \\
\hline formula weight & 935.27 & 2489.90 & 4026.72 \\
\hline $\mathrm{T} / \mathrm{K}$ & $100(2)$ & $100(2)$ & $100(2)$ \\
\hline$\lambda / \AA$ & $0.71073, \mathrm{Mo} \mathrm{K}_{a}$ & $0.71073, \mathrm{Mo} \mathrm{K}_{a}$ & $0.71073, \mathrm{Mo} \mathrm{K}_{\alpha}$ \\
\hline crystal system & triclinic & triclinic & Monoclinic \\
\hline space group & $P-1$ & $P-1$ & $P 2 / c$ \\
\hline$a / \AA$ & $10.6412(19)$ & $11.5159(14)$ & $46.461(2)$ \\
\hline$b / \AA$ & $13.780(3)$ & $26.624(3)$ & $19.6539(9)$ \\
\hline$c / \AA$ & $21.703(4)$ & $28.024(3)$ & $20.1080(9)$ \\
\hline$\alpha$ & $73.982(3)$ & $75.516(2)$ & 90 \\
\hline$\beta 1^{\circ}$ & $80.257(3)$ & $86.674(2)$ & $91.637(2)$ \\
\hline$\gamma$ & $88.739(3)$ & $89.643(2)$ & 90 \\
\hline$V / \AA^{3}$ & $3013.9(9)$ & $8304.8(17)$ & 18354.0(15) \\
\hline$Z$ & 2 & 2 & 4 \\
\hline$\rho / \mathrm{Mg} \mathrm{m}^{-3}$ & 1.031 & 0.996 & 1.457 \\
\hline$\mu / \mathrm{mm}^{-1}$ & 0.096 & 0.116 & 0.297 \\
\hline $\mathrm{F}(000)$ & 1032 & 2740 & 8256 \\
\hline crystal size $/ \mathrm{mm}^{3}$ & $0.28 / 0.27 / 0.20$ & $0.35 / 0.31 / 0.26$ & $0.44 / 0.34 / 0.13$ \\
\hline$\theta$ range $/^{\circ}$ & 1.00 to 26.8 & 0.8 to 26.9 & 1.1 to 26.0 \\
\hline \multirow[t]{3}{*}{ index ranges } & $-13 \leq h \leq 13$ & $-14 \leq h \leq 14$ & $-57 \leq h \leq 57$ \\
\hline & $-17 \leq k \leq 17$ & $-33 \leq k \leq 33$ & $-23 \leq k \leq 24$ \\
\hline & $-27 \leq l \leq 27$ & $-35 \leq l \leq 35$ & $-24 \leq l \leq 24$ \\
\hline refl. Collected & 28544 & 203651 & 240555 \\
\hline indep. reflections/ $R_{\text {int }}$ & $12812 / 0.033$ & $35572 / 0.096$ & $36138 / 0.050$ \\
\hline completeness to $\theta_{\max }$ & $99.4 \%$ & $99.5 \%$ & $99.9 \%$ \\
\hline $\begin{array}{l}\text { data/restraints/ } \\
\text { parameters }\end{array}$ & $12812 / 138 / 663$ & $35572 / 1246 / 1900$ & $36138 / 4361 / 2938$ \\
\hline GooF & 1.04 & 1.11 & 1.04 \\
\hline $\begin{array}{l}\text { final } \mathrm{R} \text { indices } \\
{[\mathrm{I}>2 \operatorname{sigma}(\mathrm{I})]} \\
R_{1} / w R_{2}\end{array}$ & $0.044 / 0.119$ & $0.095 / 0.270$ & $0.091 / 0.261$ \\
\hline $\begin{array}{l}\mathrm{R} \text { indices (all data) } \\
R_{1} / w R_{2}\end{array}$ & $0.057 / 0.111$ & $0.131 / 0.243$ & $0.111 / 0.242$ \\
\hline $\begin{array}{l}\text { largest diff. peak } \\
\text { and hole / } \mathrm{eA}^{-3}\end{array}$ & $0.42 /-0.25$ & $1.13 /-0.53$ & $1.48 /-1.19$ \\
\hline absorption correction & multi-scan & multi-scan & multi-scan \\
\hline
\end{tabular}




\section{Computational Details}

\section{Structure Optimisation, Frequency Calculation and Thermochemical Approximations}

Computational examination was performed using ORCA (version 4.2.1.). ${ }^{[15]}$ All neutral structures were optimised starting from experimental X-Ray structures on RI-BP86-D3BJ[16] def2SVP/J model chemistry[17] in the gas phase followed by a frequency calculation on the same level of theory and when necessary, thermochemical corrections were taken from these frequency calculations. For numerical accuracy, grid6 and finalgrid7 were applied. No imaginary frequencies were observed confirming true minima, except for $\mathbf{C}$ where a minor imaginary frequency of $\mathrm{i} 3 \mathrm{~cm}^{-1}$ was observed. All structures were then reoptimized using BP86-D3BJ-def2TZVP/J model chemistry and all considered SCF energies, property calculations as well as NBO analyses ${ }^{[18]}$ are based on these gas phase structures. Graphical depictions were created using ChemCraft or IBOview. ${ }^{[19]}$ For tungsten an ECP-46 was applied. ${ }^{[20]}$

Table: Thermochemical data for compounds and reactions considered:

\begin{tabular}{|c|c|c|c|c|c|c|c|c|}
\hline \multirow[b]{2}{*}{ ENTRY } & \multirow[b]{2}{*}{ MOLECULE } & \multicolumn{7}{|c|}{$\begin{array}{l}\text { BP86-D3BJ\def2TZVP (gasphase structures); Thermal corrrections from def2-SVP frequency calculations } \\
\text { in Hartee }\end{array}$} \\
\hline & & $\mathrm{E}(\mathrm{SCF})$ & $E(Z P V)_{\text {corr }}$ & $\mathbf{H}_{\text {corr }}$ & $\mathbf{G}_{\text {corr }}$ & $E(Z P V)$ & $\mathbf{H}$ & G \\
\hline 1 & $\mathrm{Et}_{2} \mathrm{O}$ & $-233,762302$ & 0,13202452 & 0,13991151 & 0,10204958 & $-233,630277$ & $-233,62239$ & $-233,660252$ \\
\hline 2 & 2 & $-2924,89269$ & 1,16317117 & 1,23484473 & 1,07235133 & $-2923,72952$ & $-2923,65785$ & $-2923,82034$ \\
\hline 3 & 3 & $-3559,27342$ & 1,20632962 & 1,29122733 & 1,10326968 & $-3558,06709$ & $-3557,98219$ & $-3558,17015$ \\
\hline 4 & $(\mathrm{THF}) \mathrm{W}(\mathrm{CO})_{5}$ & $-866,886047$ & 0,15507746 & 0,17482017 & 0,10875019 & $-866,73097$ & $-866,711227$ & $-866,777297$ \\
\hline 5 & THF & $-232,551462$ & 0,11315586 & 0,11910556 & 0,08519033 & $-232,438306$ & $-232,432357$ & $-232,466272$ \\
\hline 6 & B & $-2925,25071$ & 1,17094002 & 1,24324181 & 1,07941163 & $-2924,07977$ & $-2924,00747$ & $-2924,1713$ \\
\hline 7 & E (cis-derivative) & $-3159,038129$ & 1,307651942 & 1,387178443 & 1,210379892 & $-3157,730477$ & $-3157,650951$ & $-3157,827749$ \\
\hline 8 & D (trans isomer) & $-3159,05926$ & 1,30785914 & 1,38742207 & 1,21061359 & $-3157,7514$ & $-3157,67183$ & $-3157,84864$ \\
\hline 9 & 4 & $-3159,08411$ & 1,30877742 & 1,38794656 & 1,21222959 & $-3157,77533$ & $-3157,69616$ & $-3157,87188$ \\
\hline 10 & $\mathrm{C}$ & $-2925,26924$ & 1,17254146 & 1,24312208 & 1,08468564 & $-2924,09669$ & $-2924,02611$ & $-2924,18455$ \\
\hline 11 & {$\left[\mathrm{H}\left(\mathrm{Et}_{2} \mathrm{O}\right)_{2}\right]^{+}$} & $-467,903136$ & 0,27707353 & 0,2932832 & 0,23684338 & $-467,626063$ & $-467,609853$ & $-467,666293$ \\
\hline
\end{tabular}

\begin{tabular}{|c|c|c|c|c|c|c|}
\hline \multirow[b]{2}{*}{ ENTRY } & \multirow[b]{2}{*}{ Reactant Entries } & \multirow[b]{2}{*}{ Reaction Description } & \multicolumn{4}{|c|}{$\begin{array}{l}\text { BP86-D3BJ\def2TZVP (gasphase structures) } \\
\text { in kcal moll }\end{array}$} \\
\hline & & & $\mathrm{dE}(\mathrm{SCF})$ & $\mathrm{dE}(\mathrm{ZPV})$ & dH & dG \\
\hline RXN1 & $2-->6$ & Protonation/proton affinity $\mathbf{2}+\mathrm{H}^{+}--->\mathrm{B}$ & $-224,656357$ & $-219,781326$ & $-219,387113$ & $-220,225951$ \\
\hline RXN 2 & $2+11->8$-trans +1 & Protonation $\mathbf{2}+\left[\mathrm{H}\left(\mathrm{Et}_{2} \mathrm{O}\right)_{2}\right]^{+}--->\mathrm{D}+\mathrm{Et}_{2} \mathrm{O}$ & $-16,1437696$ & $-16,3703172$ & $-16,6422305$ & $-13,9672775$ \\
\hline RXN 3 & $2+11$--> 7-cis +1 & Protonation $\mathbf{2}+\left[\mathrm{H}\left(\mathrm{Et}_{2} \mathrm{O}\right)_{2}\right]^{+}--->\mathrm{E}+\mathrm{Et}_{2} \mathrm{O}$ & $-2,88679562$ & $-3,24336384$ & $-3,53813668$ & $-0,85695048$ \\
\hline RXN 4 & $2+11->9+1$ & Protonation $2+\left[\mathrm{H}\left(\mathrm{Et}_{2} \mathrm{O}\right)_{2}\right]^{+}--->4+\mathrm{Et}_{2} \mathrm{O}$ & $-31,7392103$ & $-31,3895327$ & $-31,9085502$ & $-28,5486594$ \\
\hline RXN5 & $6+1-->8$-trans & ether adduct formation, $\mathbf{B}+\mathrm{Et}_{2} \mathrm{O} \rightarrow-->\mathbf{D}$ & $-29,0202233$ & $-25,9488175$ & $-26,3415398$ & $-10,7268284$ \\
\hline RXN6 & 8-trans ---> 7-cis & isomer energy difference, trans-D ---> cis-E & 13,2569739 & 13,1269533 & 13,1040939 & 13,110327 \\
\hline RXN7 & 7-cis $-->9$ & Rearrangement of $\mathrm{B}$ and $\mathrm{Si}, \mathrm{E}--->4$ & $-28,8524147$ & $-28,1461689$ & $-28,3704135$ & $-27,6917089$ \\
\hline RXN8 & Umlagerung 6 -----> 10 & Isomerisation of Protonated Silylene derivatives: B --->C C & $-11,6268717$ & $-10,6219549$ & $-11,7020021$ & $-8,31738378$ \\
\hline RXN9 & $10+1--->9$ & ether adduct formation: $\mathrm{C}_{-}-->4$ & $-32,9887923$ & $-30,3460781$ & $-29,9058574$ & $-16,9908265$ \\
\hline RXN10 & $2+11--->6+1+1$ & Protonation 2+[H(Et $\left.\left.\mathrm{Et}_{2} \mathrm{O}\right)_{2}\right]^{+}--->\mathbf{B}+2 \mathrm{Et}_{2} \mathrm{O}$ & 12,87645376 & 9,578500334 & 9,699309278 & $-3,240449099$ \\
\hline RXN 11 & $2+4--->3+5$ & Complexation: $\mathbf{2}+(\mathrm{THF}) \mathrm{W}(\mathrm{CO})_{5}--->\mathbf{3}+\mathrm{THF}$ & $-28,9519632$ & $-28,1758276$ & $-28,5327951$ & $-24,3344398$ \\
\hline
\end{tabular}

Wiberg/Loewdin Bond indices for 2, $2^{\mathrm{H}}$, and [Cp*Si] ${ }^{+}$

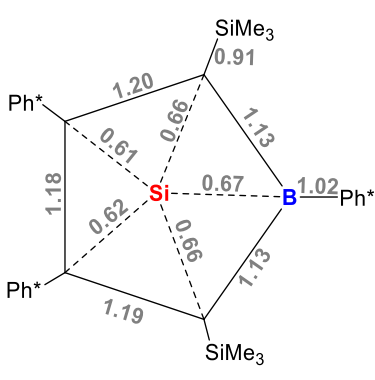

2

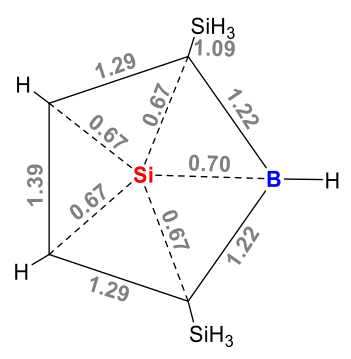

$2^{\mathrm{H}}$

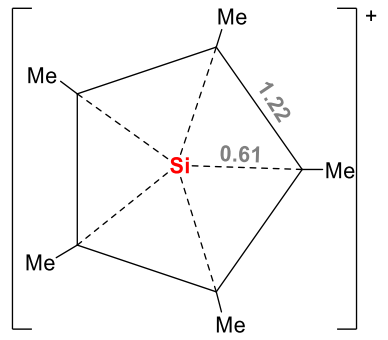

$\left[\mathrm{Cp}{ }^{*} \mathrm{Si}^{+}\right.$

Wiberg/Loewdin bond indices (RI-BP86/def2-TZVP)

Figure S8: Wiberg/Löwdin Bond indices are reported for the BP86-D3BJ-def2TZVP/J obtained structure and wavefunction. 


\section{NBO, NLMO and NRT Analyses}

NBO, NLMO and NRT analyses were conducted using NBO7.0. ${ }^{[18]}$ Wavefunctions to be analysed by NBO were obtained on the structures optimised on BP86-D3BJ-def2TZVP/J level of theory. For large molecules $\mathbf{2}$ and the cationic part of 4, a BP86 single point calculation with def2-SVP basis sets on the organic substituents and def2-TZVP basis set for the elements of the central heterocyclic $\left[\mathrm{C}_{4} \mathrm{BSi}\right]$-fragment were chosen. NRT calculations were restricted to consider resonance structures of the centra $\left[\mathrm{C}_{4} \mathrm{BSi}\right]$ unit. Depictions of NLMOs describing $\mathrm{E}(\mathrm{Si}, \mathrm{B})$ interactions with the heterocyclic $\pi$-systems in $\mathbf{2}^{\mathrm{H}}, \mathbf{2}$ and $\mathbf{4}$ or the $\mathrm{E}$ centered lone pair are given below and the composition details are listed.
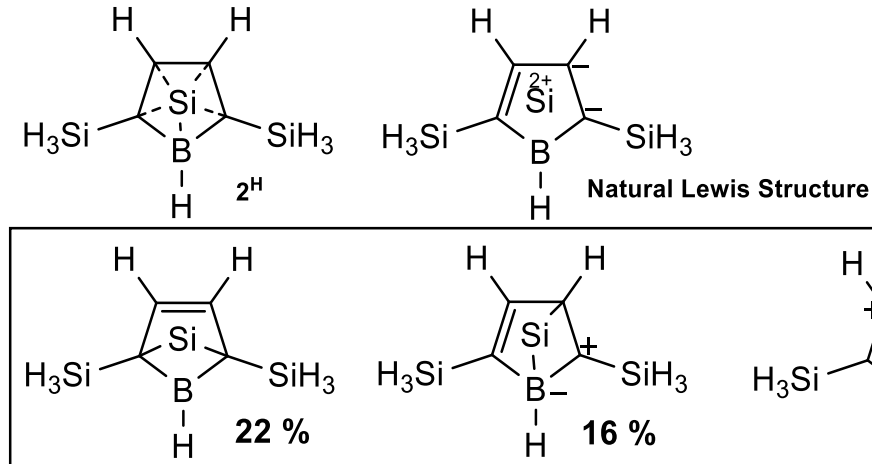

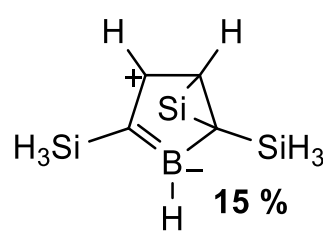<smiles></smiles><smiles>[SiH3]C1=CC2[B]C1=C2</smiles><smiles>[SiH3]C1=C([SiH3])C2C([SiH3])C12</smiles>

NRT results for $2^{\mathrm{H}}$ taking into account mirror symmetry and only considering those major contributions where the $\sigma$-scaffold of the borole ring remains intact $(\Sigma$ (contributions) $=77 \%$ )

Figure S9 NRT results for $2^{\mathrm{H}}$

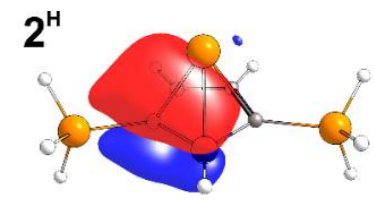

NLMO-21

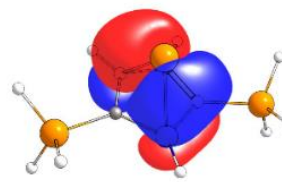

NLMO-22

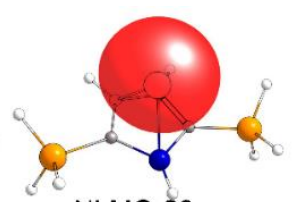

NLMO-23 RI-BP86/def2-TZVP (all atoms)
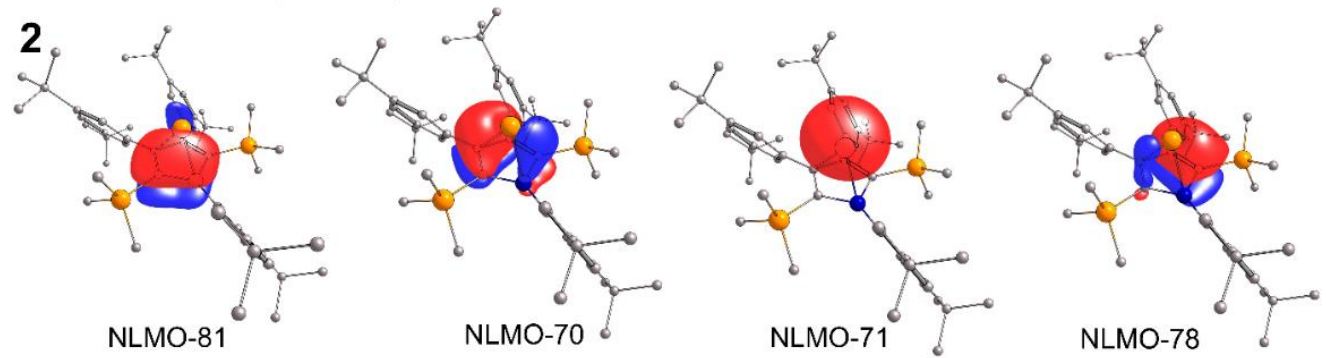

RI-BP86/def2-TZVP $\left(\mathrm{C}_{4} \mathrm{~B}-\mathrm{Si}\right.$-core $)+$ def2-SVP (all other atoms)

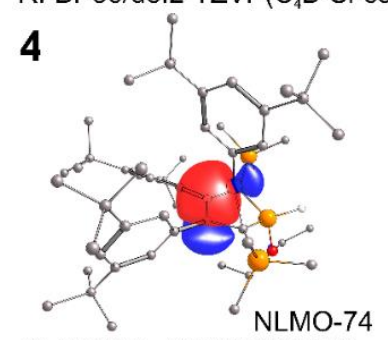

RI-BP86/def2-TZVP(C C $_{4}$ B-Si-core)+def2-SVP (all other atoms)

Figure S10 Relevant NLMOs in $\mathbf{2}^{\mathrm{H}}, \mathbf{2}$ and $\mathbf{4}$. 


\begin{tabular}{|c|c|c|c|c|c|c|}
\hline Compound & NLMO \# & $\begin{array}{l}\text { contributing } \\
\text { atoms }\end{array}$ & $\begin{array}{c}\text { atom } \\
\text { contribution } \\
{[\%]} \\
\end{array}$ & $\begin{array}{c}\text { Individual } \\
\text { S-orbital } \\
\text { contribution [\%] }\end{array}$ & $\begin{array}{c}\text { Individual } \\
\text { p-orbital } \\
\text { contribution [\%] }\end{array}$ & description \\
\hline \multirow{4}{*}{$2^{\mathrm{H}}$} & 21 & $\begin{array}{c}\text { Si(apical) } \\
\mathrm{C}_{\alpha} \\
\mathrm{C}_{\beta} \\
\mathrm{B}\end{array}$ & $\begin{array}{c}19 \\
53 \\
14.5 \\
11.8\end{array}$ & $\begin{array}{l}8.4 \\
1.8 \\
1.6 \\
1.0\end{array}$ & $\begin{array}{l}90.9 \\
97.9 \\
97.7 \\
98.5\end{array}$ & $\begin{array}{l}\text { Si p-orbital interacts with a borata- } \\
\text { allyl-dianion fragment }\end{array}$ \\
\hline & 22 & $\begin{array}{c}\text { Si(apical) } \\
\mathrm{C}_{\alpha} \\
\mathrm{C}_{\alpha} \\
\mathrm{C}_{\beta} \\
\mathrm{C}_{\beta} \\
\mathrm{B} \\
\end{array}$ & $\begin{array}{c}22.3 \\
12.4 \\
<1 \\
15.2 \\
35.2 \\
14.0 \\
\end{array}$ & $\begin{array}{c}0 \\
0.2 \\
- \\
1.1 \\
1.1 \\
0.7 \\
\end{array}$ & $\begin{array}{c}99.3 \\
99.3 \\
- \\
98.5 \\
98.5 \\
98.8 \\
\end{array}$ & $\begin{array}{l}\text { Si p-orbital interacting with a } \\
\text { borata butadiene fragment }\end{array}$ \\
\hline & 23 & Si(apical) & 99.6 & 86.9 & 3.1 & $\mathrm{Si}(\mathrm{II})$ lone pair of electrons \\
\hline & 30 & $\begin{array}{c}\text { Si(apical) } \\
\mathrm{C}_{\alpha} \\
\mathrm{C}_{\alpha} \\
\mathrm{C}_{\beta} \\
\mathrm{C}_{\beta} \\
\mathrm{B} \\
\end{array}$ & $\begin{array}{c}16.1 \\
42.7 \\
<2 \\
35.5 \\
<2 \\
<2 \\
\end{array}$ & $\begin{array}{c}6.0 \\
0.5 \\
- \\
0.9 \\
- \\
- \\
\end{array}$ & $\begin{array}{c}93.3 \\
99.2 \\
- \\
98.6 \\
- \\
- \\
\end{array}$ & $\begin{array}{c}\mathrm{C}_{\alpha}-\mathrm{C}_{\beta} \pi \text {-bond interacting with a Si } \\
\text { p-orbital }\end{array}$ \\
\hline \multirow{4}{*}{2} & 81 & $\begin{array}{c}\text { Si(apical) } \\
\mathrm{C}_{\alpha} \\
\mathrm{C}_{\alpha} \\
\mathrm{B}\end{array}$ & $\begin{array}{c}21.4 \\
45.3 \\
4.2 \\
22.5 \\
\end{array}$ & $\begin{array}{l}6.8 \\
2.3 \\
0.3 \\
1.1 \\
\end{array}$ & $\begin{array}{l}92.6 \\
97.4 \\
99.1 \\
98.5 \\
\end{array}$ & $\begin{array}{l}\text { Si p-orbital interacts with a C=B- } \\
\text { double bond }\end{array}$ \\
\hline & 70 & $\begin{array}{c}\text { Si(apical) } \\
\mathrm{C}_{\alpha} \\
\mathrm{C}_{\alpha} \\
\mathrm{C}_{\beta} \\
\mathrm{C}_{\beta} \\
\mathrm{B} \\
\end{array}$ & $\begin{array}{c}17.4 \\
6.5 \\
6.7 \\
14.1 \\
49.1 \\
3.8 \\
\end{array}$ & $\begin{array}{l}1.3 \\
0.4 \\
3.2 \\
1.0 \\
1.3 \\
1.3 \\
\end{array}$ & $\begin{array}{l}98.0 \\
98.9 \\
96.4 \\
98.7 \\
98.4 \\
97.9 \\
\end{array}$ & $\begin{array}{l}\text { Si p-orbital interacting with an allyl } \\
\text { moiety on within the borole ring }\end{array}$ \\
\hline & 71 & Si(apical) & 99.2 & 83.8 & 16.2 & Si(II) lone pair of electrons \\
\hline & 78 & $\begin{array}{c}\text { Si(apical) } \\
\mathrm{C}_{\alpha} \\
\mathrm{C}_{\alpha} \\
\mathrm{C}_{\beta} \\
\mathrm{C}_{\beta} \\
\mathrm{B} \\
\end{array}$ & $\begin{array}{c}15.5 \\
44.2 \\
2.4 \\
33.6 \\
<1 \\
2.5 \\
\end{array}$ & $\begin{array}{c}5.8 \\
0.3 \\
- \\
1.0 \\
- \\
- \\
\end{array}$ & $\begin{array}{c}93.4 \\
99.4 \\
- \\
98.7 \\
- \\
- \\
\end{array}$ & $\begin{array}{c}\mathrm{C}_{\alpha}-\mathrm{C}_{\beta} \pi \text {-bond interacting with a Si } \\
\text { p-orbital }\end{array}$ \\
\hline 4 & 74 & $\begin{array}{c}\mathrm{B} \text { (apical) } \\
\mathrm{C}_{\beta} \\
\mathrm{C}_{\beta}\end{array}$ & $\begin{array}{l}20.2 \\
37.5 \\
38.9\end{array}$ & $\begin{array}{c}14.3 \\
4.0 \\
3.6\end{array}$ & $\begin{array}{l}85.6 \\
95.7 \\
96.0\end{array}$ & $\begin{array}{l}\text { Si sp-hybrid orbital interacting with } \\
\qquad \text { a } C_{\beta}-C_{\beta} \pi \text {-bond }\end{array}$ \\
\hline
\end{tabular}

\section{QTAIM}

Topology analyses including determination of Bader charges according to Bader's quantum theory of atoms in molecules (QTAIM) ${ }^{[21]}$ were performed on the wavefunction files obtained from RI-BP86-D3BJ-def2TZVP/J optimised structures in the gasphase using the AIMAll programme suite. ${ }^{[22]}$ 


\section{ELF (Electron Localization Function)}

An ELF analysis of the wavefunction obtained from the RI-BP86-D3BJ-def2TZVP/J optimised structure of 2 was performed using multiwfn software (version 3.6). ${ }^{[23]}$ The graphical representation was then created with UCSF ChimeraX.[24]
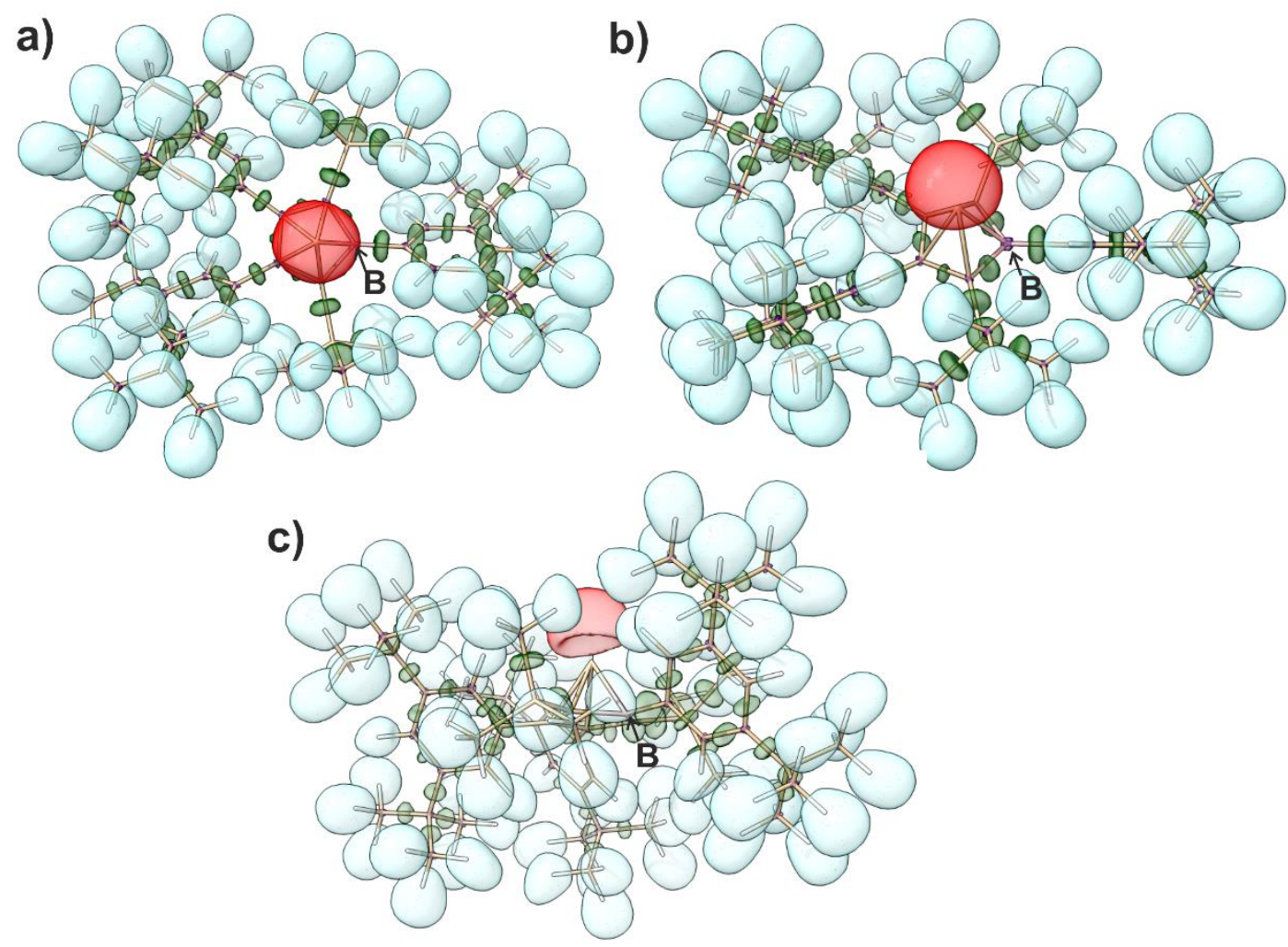

ELF isosurface plots of 2 from three perspectives a.)-c.) (isosurface value $=\mathbf{0 . 8 9}$ ) red: lone pair domain; light blue: hydrogen related domain; green: bonding domain; purple: core domain.

Figure S11 Three perspectives on the ELF isosurface plot of 2.

\section{Computational assessment of spectroscopic features}

Computational reproduction of NMR spectroscopic properties of 2, $\mathbf{3}$ and cations [4] ${ }^{+}$was performed using GIAO method and RIJK-PBEO[25] functional and def2-TZVP basis set $(\mathrm{C}, \mathrm{H})$ and def2-TZVPP basis set (all hetero-atoms) on gas phase structures previously optimised using the RI-BP86-D3BJ-def2TZVP/J model chemistry. For the cationic species we applied a polarized continuum solvation model for dichloromethane $(\mathrm{CPCM}=\mathrm{CH} 2 \mathrm{Cl} 2)$. For neutral molecules no solvation model was applied. Calculated chemical shifts were obtained according to:

$$
\delta_{\text {calc }}=\sigma_{\text {ref }}-\sigma_{\text {calc }}
$$

with $\sigma_{\text {ref }}\left({ }^{13} \mathrm{C}\right)=186.86 \mathrm{ppm}, \sigma_{\mathrm{ref}}\left({ }^{29} \mathrm{Si}\right)=332.6 \mathrm{ppm}$ and $\sigma_{\text {ref }}\left({ }^{11} \mathrm{~B}\right)=101.2 \mathrm{ppm}$.

As already reported in a recent study, ${ }^{[26]}$ for ${ }^{13} \mathrm{C}-\mathrm{NMR}$ shifts an empirical correction was determined by linear regression to be:

$$
\delta_{\text {calc, corr }}=\left(\delta_{\text {calc }}-0.70\right) / 1.0545
$$




\begin{tabular}{|c|c|c|c|c|c|c|c|c|c|c|c|c|}
\hline & \multicolumn{4}{|c|}{2} & \multicolumn{4}{|c|}{3} & \multicolumn{4}{|c|}{ cationic part of [4] ${ }^{+}$in $\mathrm{CD}_{2} \mathrm{Cl}_{2}$} \\
\hline & $\sigma_{\text {calc }}$ & $\delta_{\text {calc }}$ & $\delta_{\text {calc,corr }}$ & $\delta_{\exp }{ }^{\#}$ & $\sigma_{\text {calc }}$ & $\delta_{\text {calc }}$ & $\delta_{\text {calc,corr }}$ & $\delta_{\exp } \#$ & $\sigma_{\text {calc }}$ & $\delta_{\text {calc }}$ & $\delta_{\text {call,corr }}$ & $\delta_{\exp }$ \\
\hline \multirow{7}{*}{$\begin{array}{l}\mathrm{Si}_{-, \text {, apical“ }} \\
\mathrm{SiCH}_{3} \\
B \\
\mathrm{C}_{\alpha} \\
\mathrm{C}_{6}\end{array}$} & 706,1 & $-373,5$ & & $-349,4$ & 575,77 & $-243,17$ & & $-254,8$ & 353 & $-20,4$ & & $-16,9$ \\
\hline & 339,3 & $-6,7$ & & $-6,8$ & 338,53 & $-5,93$ & & $-5,9$ & 337,86 & $-5,26$ & & $-5,6$ \\
\hline & 75,4 & 25,8 & & 31,5 & 75,23 & 25,97 & & 34,1 & 139,77 & $-38,57$ & & $-32,4$ \\
\hline & 70,7 & 116,16 & 109,5 & 110,4 & 67,67 & 119,19 & 112,4 & 113,2 & 120,67 & 66,19 & 62,1 & 62,1 \\
\hline & 42,09 & 144,77 & 136,6 & 139,2 & 41,58 & 145,28 & 137,1 & 140,1 & 56,84 & 130,02 & 122,6 & 125,6 \\
\hline & & & & & & & & & & & & \\
\hline & & & & & & & & & & & & \\
\hline
\end{tabular}

Computationally (RIJK-PBE0/def2-TZVP(P)) assessed NMR spectroscopic properties of the key nuclei. Note: \# experimental shifts obtained from solutions in $\mathrm{C}_{6} \mathrm{D}_{6}$. 


\section{NICS $_{\text {zz }}$-scans}

$\mathrm{NICS}_{z z}$ scans $^{[27]}$ were calculated with the GIAO method and RIJK-PBE0[25] functional and def2-TZVP basis set on gas phase structures previously optimised using the RI-BP86-D3BJ-def2TZVP/J model chemistry. NICS values were calculated for a series of points along a line orthogonal to the borole (or benzene) plane on both sides dissecting it at its centroid. For $\mathbf{2}$, the apical silicon atom coincides with the NICS scan axis on one side. Comparison of the non-coordinate side of 2 reveals a similar NICS $_{z z}$ scan profile as observed for aromatic rings such as benzene or the borole dianion $\left[\mathrm{C}_{4} \mathrm{BH}_{5}\right]^{2-}$.
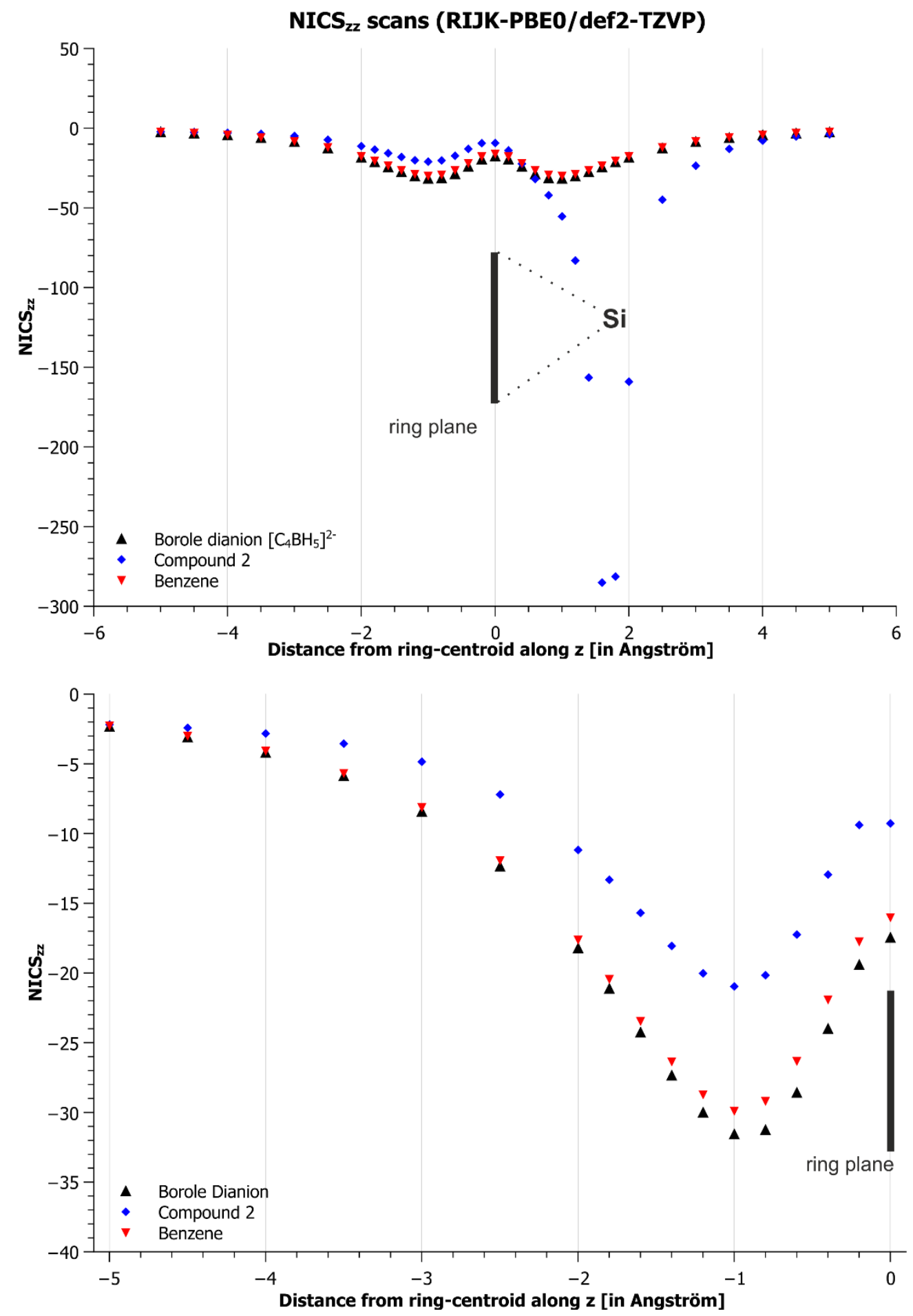

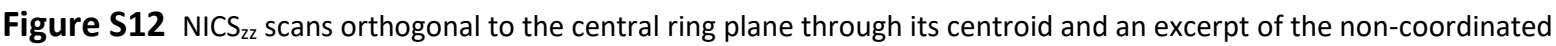
side of $\mathbf{2}$. 


\section{$\mathrm{XYZ}$-coordinates of optimised structures}

All structures optimised at RI-BP86-D3BJ \def2TZVP\J level of theory (see above).

Molecular structure of 2

$\begin{array}{llll}\text { Si } & 5.709617834 & 4.273031444 & 4.026478445\end{array}$

C $\quad 7.512003341 \quad 4.815089485 \quad 3.947340185$

B $\quad 8.313088965 \quad 5.558611239 \quad 5.050179094$

Si $\quad 11.307158243 \quad 6.166528726 \quad 5.464369577$

$\begin{array}{llll}\text { C } & 8.444996874 & 4.498746178 & 2.877694281\end{array}$

$\begin{array}{llll}\text { C } & 10.941761950 & 4.632545494 & 2.364316805\end{array}$

$\begin{array}{lllll}\text { C } & 7.759758379 & 6.062518176 & 6.423433484\end{array}$

$\begin{array}{llll}\text { C } & 9.791067478 & 5.477460969 & 4.581683735\end{array}$

$\begin{array}{lllll}\text { H } & 8.955432688 & 4.740286997 & 7.622740087\end{array}$

$\begin{array}{llll}\text { C } & 8.197215727 & 5.523758909 & 7.644072909\end{array}$

C $\quad 7.683964385 \quad 5.955298692 \quad 8.871689920$

$\begin{array}{llll}\text { C } & 6.703301081 & 6.956995709 & 8.852359289\end{array}$

$\begin{array}{llll}\text { H } & 6.287463690 & 7.302817301 & 9.800613519\end{array}$

$\begin{array}{lllll}\text { C } & 6.235545908 & 7.529849032 & 7.661816610\end{array}$

$\begin{array}{lllll}\text { C } & 6.779998996 & 7.067361944 & 6.457454082\end{array}$

$\begin{array}{llll}\mathrm{H} & 6.438888017 & 7.488161510 & 5.511549891\end{array}$

$\begin{array}{llll}\text { C } & 5.257188957 & 3.887520443 & 5.813417691\end{array}$

$\begin{array}{llll}\text { H } & 4.220724946 & 3.520858313 & 5.867740015\end{array}$

$\begin{array}{llll}H & 5.348937512 & 4.768808500 & 6.460999106\end{array}$

$\begin{array}{llll}\text { H } & 5.912294927 & 3.104434119 & 6.223400508\end{array}$

$\begin{array}{llll}\text { C } & 4.624954271 & 5.683939480 & 3.399295808\end{array}$

$\begin{array}{llll}\mathrm{H} & 4.862036864 & 5.948639212 & 2.358922929\end{array}$

$\begin{array}{llll}H & 4.766756462 & 6.583478763 & 4.015197549\end{array}$

$\begin{array}{llll}\text { H } & 3.560295930 & 5.408935839 & 3.440901431\end{array}$

$\begin{array}{llll}\text { C } & 5.397004714 & 2.717862921 & 3.004570573\end{array}$

$\begin{array}{llll}\mathrm{H} & 5.490506695 & 2.895606376 & 1.925807507\end{array}$

$\begin{array}{llll}H & 4.382699759 & 2.339962242 & 3.205282293\end{array}$

$\begin{array}{llll}\text { H } & 6.109061232 & 1.922710299 & 3.272020661\end{array}$

$\begin{array}{lllll}\text { C } & 12.104953102 & 4.837950032 & 6.543844392\end{array}$

$\begin{array}{llll}\text { H } & 12.438215372 & 3.975650607 & 5.948197563\end{array}$

$\begin{array}{llll}H & 11.393429076 & 4.467565587 & 7.296546738\end{array}$

$\begin{array}{llll}\text { H } & 12.981866662 & 5.235461250 & 7.076895480\end{array}$

$\begin{array}{llll}\text { C } & 12.563169840 & 6.830957347 & 4.223520572\end{array}$

$\begin{array}{llll}\text { H } & 13.065865607 & 6.037303546 & 3.657354360\end{array}$

$\begin{array}{llll}\text { H } & 13.330117387 & 7.413469985 & 4.756762352\end{array}$

$\begin{array}{llll}\text { H } & 12.077822717 & 7.499856952 & 3.497676603\end{array}$

$\begin{array}{llll}\text { C } & 10.772158773 & 7.608601632 & 6.548921516\end{array}$

H $\quad 10.231677108 \quad 8.360995189 \quad 5.956167161$

$\begin{array}{llll}\text { H } & 11.657520705 & 8.093917328 & 6.987486806\end{array}$

$\begin{array}{llll}\text { H } & 10.107904474 & 7.293675324 & 7.363492797\end{array}$

$\begin{array}{llll}\text { C } & 8.147456937 & 3.874281158 & 1.571930571\end{array}$

$\begin{array}{lllll}\text { C } & 7.255498628 & 4.511072983 & 0.703720928\end{array}$

$\begin{array}{llll}\text { H } & 6.753827650 & 5.416220385 & 1.048405558\end{array}$

$\begin{array}{llll}\text { C } & 7.021980098 & 4.015363813 & -0.585172949\end{array}$

$\begin{array}{llll}\text { C } & 6.027553509 & 4.739257802 & -1.501469674\end{array}$

$\begin{array}{lllll}\text { C } & 6.467257561 & 6.208354918 & -1.677369758\end{array}$

$\begin{array}{llll}\text { H } & 7.462437174 & 6.264238798 & -2.141396526\end{array}$

$\begin{array}{llll}H & 6.512636747 & 6.736872132 & -0.715527385\end{array}$

$\begin{array}{llll}\text { H } & 5.755748779 & 6.744584406 & -2.323101982\end{array}$

C $4.628677467 \quad 4.696471859 \quad-0.850055820$

$\begin{array}{llll}\mathrm{H} & 3.893950554 & 5.216426948 & -1.483186811\end{array}$

$\begin{array}{llll}H & 4.628344965 & 5.180506380 & 0.136101979\end{array}$

H $4.293749065 \quad 3.658150208 \quad-0.713770086$

$\begin{array}{llll}\text { C } & 5.938225552 & 4.093736443 & -2.892306534\end{array}$

$\begin{array}{llll}\text { H } & 5.221631876 & 4.651905312 & -3.511686517\end{array}$

$\begin{array}{llll}H & 5.590008394 & 3.052246212 & -2.837283584\end{array}$

$\begin{array}{llll}\text { H } & 6.908949823 & 4.107001017 & -3.408937740\end{array}$

$\begin{array}{llll}\text { C } & 7.716045098 & 2.864573285 & -0.984754725\end{array}$

$\begin{array}{llll}\text { H } & 7.555334547 & 2.475013204 & -1.986501491\end{array}$

$\begin{array}{llll}\text { C } & 8.618574429 & 2.205209504 & -0.137370212\end{array}$

$\begin{array}{llll}\text { C } & 9.402953486 & 0.958922134 & -0.564447242\end{array}$

$\begin{array}{llll}\text { C } & 9.020835701 & -0.216264290 & 0.360638911\end{array}$

$\begin{array}{llll}\text { H } & 7.945834325 & -0.435648981 & 0.288980625\end{array}$

$\begin{array}{llll}\text { H } & 9.249403472 & 0.009749020 & 1.411088535\end{array}$

$\begin{array}{llll}\text { H } & 9.578790020 & -1.122002751 & 0.078717066\end{array}$

$\begin{array}{llll}\text { C } & 9.112869365 & 0.554557227 & -2.017023544\end{array}$

H $\quad 9.380274495 \quad 1.355007046 \quad-2.722343093$ $\begin{array}{llll}\text { H } & 8.053065302 & 0.302277048 & -2.167112529\end{array}$

$\begin{array}{llll}\mathrm{H} & 9.706913300 & -0.332869419 & -2.278437748\end{array}$

$\begin{array}{llll}\text { C } & 10.914034697 & 1.244635685 & -0.428179542\end{array}$

$\begin{array}{llll}\text { H } & 11.496765080 & 0.351568915 & -0.700562089\end{array}$

$\begin{array}{llll}H & 11.184214329 & 1.531637417 & 0.596202587\end{array}$

H $\quad 11.219925704 \quad 2.069808759 \quad-1.086188501$

$\begin{array}{lllll}\text { C } & 8.813791517 & 2.722308757 & 1.145374298\end{array}$

H $\quad 9.510025150 \quad 2.241619319 \quad 1.832997405$

C $\quad 9.787234805 \quad 4.875523695 \quad 3.255655584$

$\begin{array}{llll}\text { C } & 10.933142922 & 5.204408969 & 1.089645640\end{array}$

$\begin{array}{llll}\text { H } & 10.086510629 & 5.830911841 & 0.808604442\end{array}$

$\begin{array}{llll}\text { C } & 11.959713726 & 4.952007945 & 0.174973775\end{array}$

$\begin{array}{llll}\text { C } & 11.873544001 & 5.564044006 & -1.228186587\end{array}$

$\begin{array}{llll}\text { C } & 11.882185828 & 7.102839561 & -1.106881631\end{array}$

$\begin{array}{llll}\text { H } & 11.812257479 & 7.565624173 & -2.102919800\end{array}$

$\begin{array}{llll}\text { H } & 12.808382756 & 7.451279369 & -0.627660581\end{array}$

$\begin{array}{llll}\text { H } & 11.035815599 & 7.462229015 & -0.505760758\end{array}$

$\begin{array}{llll}\text { C } & 10.556015910 & 5.111624455 & -1.894513006\end{array}$

$\begin{array}{llll}\text { H } & 10.459720900 & 5.563607263 & -2.893360164\end{array}$

$\begin{array}{llll}H & 9.677946360 & 5.399176189 & -1.301766060\end{array}$

$\begin{array}{llll}\text { H } & 10.526076712 & 4.018890622 & -2.005999374\end{array}$

$\begin{array}{llll}\text { C } & 13.043961741 & 5.136171408 & -2.125291118\end{array}$

$\begin{array}{llll}\mathrm{H} & 12.930281442 & 5.588889732 & -3.120714676\end{array}$

$\begin{array}{llll}\text { H } & 13.076708640 & 4.044668598 & -2.256495377\end{array}$

$\begin{array}{llll}\text { H } & 14.011657456 & 5.464018155 & -1.718566278\end{array}$

$\begin{array}{llll}\text { C } & 13.016539692 & 4.125615227 & 0.581994086\end{array}$

H $\quad 13.819435005 \quad 3.914664370 \quad-0.119433480$

C $\quad 13.062052617 \quad 3.545752128 \quad 1.858492160$

$\begin{array}{llll}\text { C } & 14.213421372 & 2.641787535 & 2.316175526\end{array}$

$\begin{array}{llll}\text { C } & 13.650611851 & 1.269726756 & 2.744219828\end{array}$

$\begin{array}{llll}\text { H } & 13.146807777 & 0.775047954 & 1.901550291\end{array}$

$\begin{array}{llll}\text { H } & 12.924273527 & 1.365161303 & 3.562701251\end{array}$

$\begin{array}{llll}\mathrm{H} & 14.464502177 & 0.615350236 & 3.090761854\end{array}$

$\begin{array}{llll}\text { C } & 15.251966266 & 2.412712889 & 1.208188957\end{array}$

H $14.805068511 \quad 1.929724004 \quad 0.327057795$

$\begin{array}{llll}\text { H } & 16.049962600 & 1.755200439 & 1.581762203\end{array}$

H $15.719790145 \quad 3.354320331 \quad 0.886419912$

$\begin{array}{llll}\text { C } & 14.916667556 & 3.305908090 & 3.519414707\end{array}$

$\begin{array}{llll}\text { H } & 15.744308503 & 2.674917374 & 3.877013147\end{array}$

$\begin{array}{llll}\text { H } & 14.222296399 & 3.460446490 & 4.356663133\end{array}$

$\begin{array}{llll}\text { H } & 15.326624067 & 4.286762393 & 3.238717876\end{array}$

$\begin{array}{llll}\text { C } & 12.005713915 & 3.807980811 & 2.738123222\end{array}$

$\begin{array}{llll}\text { H } & 11.988072309 & 3.353077491 & 3.729889203\end{array}$

$\begin{array}{llll}\text { C } & 8.153622208 & 5.378458748 & 10.213143143\end{array}$

$\begin{array}{llll}\text { C } & 5.152878051 & 8.615339246 & 7.719648678\end{array}$

$\begin{array}{llll}\text { C } & 5.672501410 & 9.811183929 & 8.545571522\end{array}$

$\begin{array}{llll}\text { H } & 5.928973982 & 9.512422958 & 9.571193784\end{array}$

$\begin{array}{llll}H & 6.574417004 & 10.238887205 & 8.084591868\end{array}$

$\begin{array}{llll}\text { H } & 4.906376179 & 10.599386415 & 8.603641954\end{array}$

$\begin{array}{lllll}\text { C } & 4.763275934 & 9.124606008 & 6.323692868\end{array}$

$\begin{array}{llll}\mathrm{H} & 5.621611512 & 9.565261880 & 5.796511973\end{array}$

$\begin{array}{llll}H & 4.351328940 & 8.319468338 & 5.698088854\end{array}$

$\begin{array}{llll}H & 3.991228348 & 9.902110445 & 6.416717812\end{array}$

$\begin{array}{lllll}\text { C } & 3.890399100 & 8.034686615 & 8.392036191\end{array}$

$\begin{array}{lllll}\text { H } & 3.504744682 & 7.178883059 & 7.819402153\end{array}$

$\begin{array}{llll}\mathrm{H} & 4.099744336 & 7.688479217 & 9.413405457\end{array}$

$\begin{array}{lllll}H & 3.099566770 & 8.798277914 & 8.447756347\end{array}$

$\begin{array}{llll}\text { C } & 8.737130757 & 6.516371500 & 11.077747325\end{array}$

$\begin{array}{lllll}\text { H } & 9.078273934 & 6.124452845 & 12.048088588\end{array}$

$\begin{array}{llll}H & 9.594390289 & 6.986052584 & 10.574202788\end{array}$

$\begin{array}{lllll}\text { H } & 7.991580506 & 7.299453516 & 11.272034734\end{array}$

$\begin{array}{llll}\text { C } & 6.951918140 & 4.741397115 & 10.942477811\end{array}$

$\begin{array}{lllll}\text { H } & 6.519174613 & 3.928887803 & 10.341308896\end{array}$

$\begin{array}{llll}\text { H } & 7.267263514 & 4.325362118 & 11.911532614\end{array}$

$\begin{array}{llll}\text { H } & 6.159014416 & 5.477850085 & 11.132076455\end{array}$

C $\quad 9.238255463 \quad 4.304833679 \quad 10.036044081$

$\begin{array}{llll}\text { H } & 9.543668101 & 3.922443823 & 11.020741438\end{array}$

H $\quad 8.875428343 \quad 3.452573785 \quad 9.443607720$ 
$\begin{array}{llll}\mathrm{H} & 10.133775651 & 4.710699879 & 9.543231817\end{array}$

Si $\quad 9.015589177 \quad 3.514799726 \quad 4.661733726$

Molecular structure of 3

$\begin{array}{llll}\text { Si } & 5.576260137 & 4.493901003 & 3.865533319\end{array}$

$\begin{array}{llll}\text { C } & 7.413416390 & 4.935601081 & 3.862189794\end{array}$

$\begin{array}{lllll}\text { B } & 8.194135731 & 5.694743516 & 4.982628766\end{array}$

Si $\quad 11.157001479 \quad 6.447784666 \quad 5.361889564$

$\begin{array}{llll}\text { C } & 8.372838422 & 4.612314618 & 2.804579030\end{array}$

$\begin{array}{llll}\text { C } & 10.896022666 & 4.675576269 & 2.382870961\end{array}$

$\begin{array}{llll}\text { C } & 7.683461100 & 6.096426755 & 6.403740986\end{array}$

$\begin{array}{llll}\text { C } & 9.687456380 & 5.590752892 & 4.538353305\end{array}$

$\begin{array}{llll}\text { H } & 9.064614139 & 4.790853725 & 7.413590537\end{array}$

$\begin{array}{lllll}\text { C } & 8.255172118 & 5.509929207 & 7.546542023\end{array}$

$\begin{array}{llll}\text { C } & 7.812607635 & 5.813426212 & 8.837196264\end{array}$

$\begin{array}{llll}\text { C } & 6.764194741 & 6.735608632 & 8.963159810\end{array}$

$\begin{array}{llll}\text { H } & 6.399602440 & 6.980818864 & 9.962289474\end{array}$

C $\quad 6.165371310 \quad 7.353806565 \quad 7.856929400$

$\begin{array}{llll}\text { C } & 6.643036339 & 7.019906972 & 6.583646907\end{array}$

$\begin{array}{llll}\mathrm{H} & 6.203447454 & 7.485172311 & 5.702493626\end{array}$

$\begin{array}{llll}\text { C } & 5.108760180 & 3.882483861 & 5.579879391\end{array}$

$\begin{array}{llll}\text { H } & 4.014782179 & 3.799161006 & 5.665161523\end{array}$

$\begin{array}{llll}\text { H } & 5.468100928 & 4.547633060 & 6.375220512\end{array}$

$\begin{array}{llll}\text { H } & 5.527892965 & 2.882212569 & 5.756811458\end{array}$

$\begin{array}{llll}\text { C } & 4.631596826 & 6.068543424 & 3.434041778\end{array}$

$\begin{array}{lllll}\mathrm{H} & 4.946246436 & 6.462642238 & 2.456294134\end{array}$

$\begin{array}{llll}\text { H } & 4.792469549 & 6.857208377 & 4.181088184\end{array}$

$\begin{array}{llll}\text { H } & 3.551139931 & 5.866576971 & 3.380845622\end{array}$

$\begin{array}{llll}\text { C } & 5.104626477 & 3.166788494 & 2.616457474\end{array}$

H $5.058559355 \quad 3.559854595 \quad 1.593703201$

$\begin{array}{llll}\text { H } & 4.108514256 & 2.776643479 & 2.877648833\end{array}$

$\begin{array}{llll}\text { H } & 5.802437035 & 2.321035941 & 2.612421197\end{array}$

C $\quad 12.125823379 \quad 5.308355542 \quad 6.500095916$

$\begin{array}{llll}\text { H } & 12.554033845 & 4.450389669 & 5.966031824\end{array}$

$\begin{array}{llll}\text { H } & 11.492365787 & 4.916486791 & 7.306900356\end{array}$

$\begin{array}{llll}\text { H } & 12.956496726 & 5.858964483 & 6.967155135\end{array}$

$\begin{array}{llll}\text { C } & 12.291386631 & 7.146590703 & 4.027202703\end{array}$

$\begin{array}{llll}\text { H } & 12.856120688 & 6.369101963 & 3.497976362\end{array}$

$\begin{array}{llll}\mathrm{H} & 13.009904586 & 7.838959222 & 4.492121203\end{array}$

$\begin{array}{llll}\text { H } & 11.718790156 & 7.711913314 & 3.277546675\end{array}$

$\begin{array}{lllll}\text { C } & 10.495562179 & 7.899301771 & 6.360434671\end{array}$

$\begin{array}{lllll}\text { H } & 9.852964887 & 8.542634921 & 5.742082671\end{array}$

$\begin{array}{llll}\text { H } & 11.337517343 & 8.508677865 & 6.723104883\end{array}$

$\begin{array}{llll}H & 9.904166440 & 7.575128500 & 7.225839985\end{array}$

$\begin{array}{llll}\text { C } & 8.093808637 & 3.946278552 & 1.517044853\end{array}$

$\begin{array}{lllll}\text { C } & 7.280945757 & 4.597086567 & 0.584520621\end{array}$

$\begin{array}{llll}\text { H } & 6.820298575 & 5.545323078 & 0.866174054\end{array}$

$\begin{array}{llll}\text { C } & 7.073966932 & 4.057379943 & -0.690536563\end{array}$

$\begin{array}{llll}\text { C } & 6.177959327 & 4.803866636 & -1.687079542\end{array}$

$\begin{array}{llll}\text { C } & 6.753014220 & 6.215761432 & -1.930342578\end{array}$

$\begin{array}{llll}\mathrm{H} & 7.763578613 & 6.156632088 & -2.359098334\end{array}$

$\begin{array}{llll}H & 6.814247797 & 6.794613261 & -0.998626168\end{array}$

$\begin{array}{llll}\text { H } & 6.113758016 & 6.772421348 & -2.631902315\end{array}$

$\begin{array}{llll}\text { C } & 4.757821440 & 4.924724754 & -1.094438545\end{array}$

H $4.097489243 \quad 5.464436438 \quad-1.789731499$

$\begin{array}{llll}\text { H } & 4.762273918 & 5.471764129 & -0.141419046\end{array}$

$\begin{array}{lllll}\text { H } & 4.325354768 & 3.930752736 & -0.910628097\end{array}$

$\begin{array}{llll}\text { C } & 6.081808831 & 4.082059846 & -3.039300334\end{array}$

H $\quad 5.434055678 \quad 4.655765996 \quad-3.717414729$

$\begin{array}{llll}H & 5.648391268 & 3.076983051 & -2.934945208\end{array}$

H $7.066456565 \quad 3.985958069-3.519338000$

$\begin{array}{llll}\text { C } & 7.708648444 & 2.846909786 & -1.004081901\end{array}$

$\begin{array}{llll}\text { H } & 7.565595401 & 2.419968573 & -1.993156485\end{array}$

$\begin{array}{llll}\text { C } & 8.533680196 & 2.174679905 & -0.090807880\end{array}$

$\begin{array}{lllll}\text { C } & 9.259539555 & 0.867809125 & -0.428082107\end{array}$

$\begin{array}{llll}\text { C } & 8.790892909 & -0.230483549 & 0.549807150\end{array}$

$\begin{array}{lllll}\text { H } & 7.707703428 & -0.395740371 & 0.462733604\end{array}$

$\begin{array}{llll}H & 9.006195736 & 0.039578985 & 1.590763037\end{array}$

$\begin{array}{llll}\mathrm{H} & 9.306488060 & -1.178282170 & 0.335104981\end{array}$

$\begin{array}{llll}\text { C } & 8.979831276 & 0.397376699 & -1.862559337\end{array}$ $\begin{array}{llll}\text { H } & 9.310282019 & 1.138051229 & -2.605606330\end{array}$

$\begin{array}{llll}H & 7.910886033 & 0.196696902 & -2.025783520\end{array}$

$\begin{array}{llll}\text { H } & 9.527556671 & -0.535809054 & -2.056490158\end{array}$

C $\quad \begin{array}{llll}10.780846503 & 1.083911385 & -0.270862827\end{array}$

$\begin{array}{llll}\text { H } & 11.319454339 & 0.142455585 & -0.455057083\end{array}$

H $11.044649399 \quad 1.433242097 \quad 0.734575736$

H $\quad 11.145484561 \quad 1.833965120 \quad-0.986503552$

$\begin{array}{llll}\text { C } & 8.710146209 & 2.741061787 & 1.174345792\end{array}$

$\begin{array}{llll}\text { H } & 9.354538543 & 2.257712785 & 1.907821491\end{array}$

$\begin{array}{lllll}\text { C } & 9.709482669 & 4.980831561 & 3.204931982\end{array}$

C $\quad 10.929661224 \quad 5.111941498 \quad 1.059550251$

H $\quad 10.084450975 \quad 5.683473805 \quad 0.677072020$

$\begin{array}{llll}\text { C } & 12.011991780 & 4.806456927 & 0.224034030\end{array}$

C $\quad 11.996372932 \quad 5.301082496 \quad-1.226861188$

C $\quad \begin{array}{llll}12.023953745 & 6.844901510 & -1.222048881\end{array}$

$\begin{array}{llll}\mathrm{H} & 12.009622888 & 7.231137829 & -2.252439574\end{array}$

$\begin{array}{lllll}\text { H } & 12.930952098 & 7.217699644 & -0.724874311\end{array}$

$\begin{array}{llll}\text { H } & 11.154727424 & 7.258288182 & -0.692148133\end{array}$

C $\quad 10.705411639 \quad 4.818131765 \quad-1.921140023$

H $\quad 10.665627578 \quad 5.197436566 \quad-2.953366332$

H $\quad 9.803951122 \quad 5.160595350 \quad-1.397051799$

H $\quad 10.662425050 \quad 3.721049665 \quad-1.955673360$

C $\quad 13.200945551 \quad 4.789228680 \quad-2.029662083$

H $13.133987781 \quad 5.150179866 \quad-3.065909509$

H $\quad 13.230251979 \quad 3.690157883 \quad-2.058955220$

H $\quad 14.152920182 \quad 5.149491760 \quad-1.613517076$

C $\quad 13.064569235 \quad 4.064814023 \quad 0.766277513$

$\begin{array}{llll}\text { H } & 13.913532999 & 3.811796725 & 0.133089140\end{array}$

C $\quad 13.071511293 \quad 3.625226141 \quad 2.103532378$

C $\quad \begin{array}{llll}\text { C } & 14.275382482 & 2.836577564 & 2.631234109\end{array}$

C $\quad 14.126920035 \quad 2.472994755 \quad 4.116053324$

H $13.248750526 \quad 1.840055959 \quad 4.298217175$

$\begin{array}{llll}\text { H } & 14.046221209 & 3.369975892 & 4.746620488\end{array}$

$\begin{array}{llll}\text { H } & 15.012477238 & 1.913656015 & 4.449181215\end{array}$

C $\quad 14.429239679 \quad 1.534893374 \quad 1.816288152$

$\begin{array}{llll}\text { H } & 13.537670191 & 0.902684557 & 1.920801562\end{array}$

$\begin{array}{llll}\mathrm{H} & 15.301363245 & 0.965613109 & 2.171380573\end{array}$

$\begin{array}{llll}\text { H } & 14.574375186 & 1.743693690 & 0.747390411\end{array}$

$\begin{array}{llll}\text { C } & 15.546518436 & 3.698674115 & 2.472486830\end{array}$

$\begin{array}{llll}\mathrm{H} & 16.424700934 & 3.152406591 & 2.847969003\end{array}$

$\begin{array}{llll}\text { H } & 15.455284159 & 4.635993903 & 3.040209654\end{array}$

$\begin{array}{llll}\text { H } & 15.733524386 & 3.957361525 & 1.421357248\end{array}$

C $\quad 11.968882007 \quad 3.934393736 \quad 2.899837459$

H $11.916865775 \quad 3.592854385 \quad 3.932705195$

$\begin{array}{llll}\text { C } & 8.426555411 & 5.181429447 & 10.092239524\end{array}$

C $\quad 5.018501383 \quad 8.348509178 \quad 8.076660531$

C $\quad 5.520180344 \quad 9.521312239 \quad 8.945539144$

$\begin{array}{llll}\text { H } & 5.880405805 & 9.174039221 & 9.923564876\end{array}$

$\begin{array}{llll}H & 6.348778077 & 10.046493393 & 8.449021831\end{array}$

$\begin{array}{llll}\text { H } & 4.708179479 & 10.243387123 & 9.120390834\end{array}$

$\begin{array}{lllll}\text { C } & 4.481089989 & 8.919157004 & 6.755608587\end{array}$

$\begin{array}{llll}\mathrm{H} & 5.259756560 & 9.458583302 & 6.197252212\end{array}$

$\begin{array}{llll}H & 4.075816100 & 8.128941021 & 6.107123090\end{array}$

$\begin{array}{llll}\mathrm{H} & 3.667067637 & 9.628244679 & 6.964220568\end{array}$

$\begin{array}{llll}\text { C } & 3.859165219 & 7.629885988 & 8.799722881\end{array}$

$\begin{array}{llll}\mathrm{H} & 3.490416002 & 6.786250881 & 8.198731548\end{array}$

$\begin{array}{llll}\text { H } & 4.173720493 & 7.235084429 & 9.775375740\end{array}$

$\begin{array}{llll}\mathrm{H} & 3.023488934 & 8.325791607 & 8.969012143\end{array}$

C $\quad 8.977694233 \quad 6.298838975 \quad 11.003322471$

H $\quad 9.422053368 \quad 5.865810171 \quad 11.912210019$

$\begin{array}{llll}H & 9.753555778 & 6.878596686 & 10.482555376\end{array}$

H $\quad 8.187261035 \quad 6.996130697 \quad 11.312926974$

$\begin{array}{llll}\text { C } & 7.337181424 & 4.389264212 & 10.845775258\end{array}$

$\begin{array}{llll}\mathrm{H} & 6.932196640 & 3.588243569 & 10.212438346\end{array}$

$\begin{array}{llll}H & 7.756805363 & 3.933977415 & 11.755673779\end{array}$

H $\quad 6.503001270 \quad 5.038344396 \quad 11.146168102$

$\begin{array}{llll}\text { C } & 9.579641225 & 4.223949260 & 9.756134176\end{array}$

H $\quad 9.988351783 \quad 3.797035965 \quad 10.682967375$

$\begin{array}{llll}H & 9.247093931 & 3.388848312 & 9.125342546\end{array}$

$\begin{array}{llll}H & 10.400629168 & 4.741873887 & 9.239918742\end{array}$

Si $\quad 8.873435404 \quad 3.733530232 \quad 4.621544816$

W $\quad 9.182712548 \quad 1.402428828 \quad 5.481054441$ 


$\begin{array}{cccc}\text { C } & 7.874028229 & 1.869588229 & 7.003431077 \\ \text { C } & 10.776783315 & 1.932965553 & 6.669275151 \\ \text { C } & 10.493730995 & 0.880998970 & 3.995067078 \\ \text { C } & 7.627155798 & 0.754083867 & 4.304185667 \\ \text { C } & 9.324435008 & -0.471102876 & 6.233961523 \\ \text { O } & 7.144499351 & 2.085077001 & 7.873433980 \\ \text { O } & 9.400077091 & -1.544235554 & 6.663616667 \\ \text { O } & 6.767408428 & 0.331767302 & 3.656295818 \\ \text { O } & 11.683655224 & 2.157715427 & 7.350383523 \\ \text { O } & 11.234735135 & 0.530494632 & 3.176482594\end{array}$

\section{Cationic Part of 4}

Si 6.035073984

C 7.580617186

B 8.979019603

Si 11.966391666

7.988473773

10.132448921

9.230077643

10.095310376

10.590987724

10.124605722

10.428684011

9.783540659

10.006704605

8.870734000

8.615188485

7.930191449

6.618917584

5.780108885

7.051536187

7.383556134

4.800044189

4.547503379

5.184723240

3.860722499

5.269935137

4.901531654

4.425415027

6.004319406

12.944919299

13.138123413

12.429081517

13.915364462

12.575789053

12.310746747

13.671209519

12.163835345

12.195475445

11.656006638

13.259842171

11.852268665

7.055087923

5.826310886

5.602809413

4.896775072

3.544947060

3.763452655

4.378099077

4.261314529

2.796964567

2.710900971

1.734577272

3.219977543

2.534537126

2.756588026

H 1.815737499

H 2.495411646

H 3.319299817

C $\quad 5.244104277$
$4.741093722 \quad 5.452662499$

$5.199525094 \quad 4.467079648$

$4.201561417 \quad 4.506402459$

$5.623551380 \quad 4.262965117$

$4.702312647 \quad 3.135655388$

$4.131311931 \quad 1.843500069$

$2.797279341 \quad 5.108367155$

$5.435568559 \quad 4.081759311$

$3.579021357 \quad 6.581819750$

$2.676103790 \quad 6.187969449$

$1.435516296 \quad 6.750706013$

$0.302404459 \quad 6.223303124$

$-0.670706125 \quad 6.657961398$

$0.377428126 \quad 5.167215754$

$1.641980487 \quad 4.612070595$

$1.728325890 \quad 3.767730331$

$4.584177859 \quad 7.235491668$

$4.312754894 \quad 7.893174682$

$5.517472807 \quad 7.625592232$

$3.798056327 \quad 7.320422105$

$6.165260366 \quad 5.346071393$

$6.440441805 \quad 4.312611484$

$7.062643078 \quad 5.853380710$

$5.893084152 \quad 5.849887371$

$3.115099324 \quad 4.926346574$

$3.121861214 \quad 3.893996406$

$2.882746497 \quad 5.592682138$

$2.304414625 \quad 5.025616585$

$4.030760087 \quad 4.423822653$

$3.590252477 \quad 3.438071761$

$3.282405588 \quad 5.039476409$

$4.251628563 \quad 4.893451743$

$6.577056772 \quad 2.758589183$

$6.049118533 \quad 1.831222657$

$6.674046339 \quad 2.790063599$

$7.595670127 \quad 2.704183829$

$6.650045595 \quad 5.827109848$

$7.609054726 \quad 5.783984101$

$6.884372706 \quad 5.975181967$

$6.109285318 \quad 6.721622122$

$4.060735891 \quad 2.190185862$

$4.698939188 \quad 1.993261811$

$5.588093015 \quad 2.582394873$

$4.222463099 \quad 1.059455989$

$4.928216792 \quad 0.899064506$

$6.444365815 \quad 0.714090637$

$6.647301001-0.174625622$

$6.896538075 \quad 1.583645297$

$6.952571016 \quad 0.586647651$

$4.681328984 \quad 2.175051002$

$5.181909447 \quad 2.097940567$

$5.066024494 \quad 3.069288794$

$3.606718328 \quad 2.324745568$

$4.404486359-0.311261624$

$4.963790033-0.407486280$

$3.342484081-0.202173109$

$4.528909305-1.247696268$

$3.084279890 \quad 0.325893228$ (a)

(a)$$
\text { (a) }
$$$$
\text { (a) }
$$

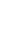

tas

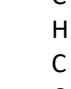$$
\text { can }
$$

c

$$
\begin{aligned}
& \text {, } \\
& \text { 每 }
\end{aligned}
$$$$
\text { 每 }
$$

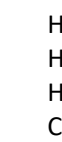

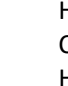

4.538247958

$6.474175519 \quad 2.422397004$

$\begin{array}{ll}6.786668743 & 1.165798021\end{array}$

$6.029236578-0.021646444$

$4.944306739 \quad 0.154933497$

6.345189768

6.227358235

6.327158521

6.791777585

5.237671869

6.617166717

8.291901301

8.487687966

8.675744223

8.877009243

7.372291852

8.331686971

9.401428952

10.063554701

9.460902058

10.733874075

10.606360644

11.118535251

11.029233915

12.175135223

10.543600423

9.118163574

8.991780662

8.489650054

8.740856416

11.410804442

11.288063004

11.065594290

12.485302624

11.472321620

11.997512257

11.550423441

12.365393701

12.274873896

11.236808247

12.709704868

12.832102908

11.841112389

10.798475801

12.447828082

11.885347773

13.844770300

14.453700997

14.242938017

13.970529518

10.869484410

10.875391883

11.442820013

8.173619567

8.428858445

9.494713594

8.078567733

7.886942655

6.651262956

6.246210692

6.396417128

6.141362199

C 8.704454527

H 8.562658309

H 9.777157447

H 8.173472549

C $\quad 10.765802139$

H 11.486956028

H 9.923537435

H 10.380971953

C $\quad 12.614789883$

H 13.112240723

$-0.405196899$

0.488853333

$-0.331921716$

0.302162401

0.300504735

$-0.177508292 \quad 1.343028501$

$-0.946631902-0.259218741$

$1.340103388-1.793676201$

$2.224212638-2.252777993$

$1.444292382-1.881089714$

$0.457230677-2.380673583$

$0.858272985-0.342475637$

$-0.018375769-0.975180436$

$0.625905557 \quad 0.659215629$

$1.702069175-0.733621130$

$2.921260097 \quad 1.434435401$

$2.435637089 \quad 1.584895458$

$4.809853731 \quad 2.936194126$

$4.638258409 \quad 0.549295533$

$5.527718997 \quad 0.360967734$

$3.998506852-0.505986751$

$4.564503299-1.924397967$

$6.020467108-1.938359418$

$6.446075901-2.948356383$ 


$\begin{array}{cccc}\text { H } & 13.360048389 & 0.263871229 & 8.176888047 \\ \text { H } & 12.271835126 & -0.590161524 & 7.060239465 \\ \text { C } & 12.007052263 & 2.620034686 & 8.361210004 \\ \text { H } & 12.722073789 & 2.453066438 & 9.178619021 \\ \text { H } & 12.542971429 & 3.145004372 & 7.556753715 \\ \text { H } & 11.215218409 & 3.281925189 & 8.741825819 \\ \text { Si } & 8.859717144 & 6.362225823 & 5.031481672 \\ \text { H } & 9.070331080 & 6.535823727 & 6.479764379 \\ \text { O } & 8.663163147 & 8.165230728 & 4.505490071 \\ \text { C } & 7.472747753 & 8.934324291 & 4.965148663 \\ \text { H } & 7.605513625 & 9.938773457 & 4.543191985 \\ \text { H } & 6.585235586 & 8.464637118 & 4.520471660 \\ \text { C } & 9.078573003 & 8.476725193 & 3.106538821 \\ \text { C } & 7.413332278 & 8.964493157 & 6.473394971 \\ \text { H } & 8.343582286 & 9.355068045 & 6.904868796 \\ \text { H } & 6.591076511 & 9.632239562 & 6.766872286 \\ \text { H } & 7.204103131 & 7.977698019 & 6.905078518 \\ \text { H } & 9.310471326 & 9.549739457 & 3.117510614 \\ \text { H } & 10.005914732 & 7.908348134 & 2.978015416 \\ \text { C } & 8.040612309 & 8.103667218 & 2.073350727 \\ \text { H } & 7.801419608 & 7.033237015 & 2.110309039 \\ \text { H } & 7.115614469 & 8.685420423 & 2.173290345 \\ \text { H } & 8.458341601 & 8.319965526 & 1.079770044\end{array}$

$\begin{array}{cccc}2^{\mathrm{H}} & & & \\ \mathrm{Si} & 5.734662866 & 4.231482241 & 4.037226901 \\ \mathrm{C} & 7.507077469 & 4.815225925 & 4.036141890 \\ \mathrm{~B} & 8.343220716 & 5.349231893 & 5.224272960 \\ \mathrm{Si} & 11.326770962 & 6.047339653 & 5.496323294 \\ \mathrm{C} & 8.350283957 & 4.847264230 & 2.857971437 \\ \mathrm{C} & 9.755933600 & 5.545514435 & 4.622909844 \\ \mathrm{C} & 9.668272312 & 5.275196345 & 3.201830618 \\ \mathrm{Si} & 9.180991068 & 3.524412274 & 4.285508543 \\ \mathrm{H} & 8.021432031 & 5.415688826 & 6.375025379 \\ \mathrm{H} & 10.498786822 & 5.295937428 & 2.495723340 \\ \mathrm{H} & 8.067838145 & 4.506610641 & 1.861498331 \\ \mathrm{H} & 12.529099419 & 5.467815569 & 4.818693027 \\ \mathrm{H} & 11.457219680 & 7.535751214 & 5.476658193 \\ \mathrm{H} & 11.292877186 & 5.583906100 & 6.913094386 \\ \mathrm{H} & 5.386019683 & 3.661585868 & 5.370217346 \\ \mathrm{H} & 4.827611386 & 5.383948807 & 3.751173719 \\ \mathrm{H} & 5.509111518 & 3.191640981 & 2.984388092\end{array}$

Cation $\mathbf{4}^{\mathrm{H}}$

$\begin{array}{lccc}\mathrm{Si} & 6.081128951 & 4.853438001 & 5.689312832 \\ \mathrm{C} & 7.634768797 & 5.222006605 & 4.702911657 \\ \mathrm{~B} & 9.053230955 & 4.251478216 & 4.618450964 \\ \mathrm{Si} & 11.941203803 & 5.484359005 & 3.928969314 \\ \mathrm{C} & 7.900994865 & 4.619434613 & 3.393215938 \\ \mathrm{H} & 9.678064246 & 4.162189528 & 2.188721939 \\ \mathrm{H} & 9.303166594 & 3.183243944 & 5.063443080 \\ \mathrm{C} & 10.063092380 & 5.485382965 & 3.975703906 \\ \mathrm{H} & 6.382718016 & 5.112520518 & 7.124851051 \\ \mathrm{H} & 5.014471349 & 5.792485522 & 5.233957204 \\ \mathrm{H} & 5.659552252 & 3.443108264 & 5.470564775 \\ \mathrm{H} & 12.425928663 & 4.189553135 & 3.377917538 \\ \mathrm{H} & 12.371132936 & 6.612642596 & 3.050780686 \\ \mathrm{H} & 12.437804803 & 5.713958957 & 5.312544194 \\ \mathrm{H} & 7.235425982 & 3.898577124 & 2.919859178 \\ \mathrm{C} & 9.249823204 & 4.765447053 & 2.988258860 \\ \mathrm{Si} & 8.944243452 & 6.449806384 & 5.049916053 \\ \mathrm{H} & 9.345970257 & 6.643155209 & 6.454423543 \\ \mathrm{O} & 8.637566369 & 8.199088152 & 4.526787492 \\ \mathrm{C} & 7.316079026 & 8.815379105 & 4.869799629 \\ \mathrm{H} & 7.395845237 & 9.853576859 & 4.525012132 \\ \mathrm{H} & 6.550984118 & 8.288513572 & 4.284658432 \\ \mathrm{C} & 9.229202959 & 8.659429719 & 3.230057877 \\ \mathrm{C} & 7.075721118 & 8.729064067 & 6.357085819 \\ \mathrm{H} & 7.882991480 & 9.206489260 & 6.926142379 \\ \mathrm{H} & 6.138474504 & 9.258636301 & 6.578970114\end{array}$

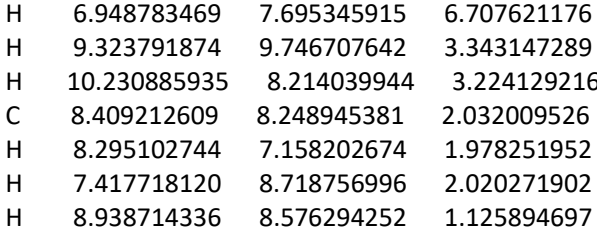

\section{Cation B}

Si $\quad 5.700178388 \quad 4.108891853 \quad 4.034489661$

$\begin{array}{llll}C & 7.526777759 & 4.675465121 & 3.996603367\end{array}$

$\begin{array}{lllll}\text { B } & 8.324068115 & 5.451534229 & 5.154788417\end{array}$

Si $\quad \begin{array}{llll}11.397398420 & 6.016364471 & 5.577884167\end{array}$

C $\quad 8.466909170 \quad 4.493698802 \quad 2.887791260$

$\begin{array}{llll}\text { C } & 10.967820662 & 4.610783577 & 2.398724408\end{array}$

$\begin{array}{llll}\text { C } & 7.756530542 & 6.008065412 & 6.474971019\end{array}$

C $\quad 9.854868048 \quad 5.309050886 \quad 4.680726949$

$\begin{array}{llll}\mathrm{H} & 9.090164121 & 4.898013361 & 7.753960212\end{array}$

$\begin{array}{llll}\text { C } & 8.269242100 & 5.614404246 & 7.723505895\end{array}$

$\begin{array}{llll}\text { C } & 7.740595769 & 6.106481229 & 8.919296987\end{array}$

C $\quad 6.684527125 \quad 7.026217234 \quad 8.830885196$

$\begin{array}{llll}\text { H } & 6.262266359 & 7.422756442 & 9.755237296\end{array}$

$\begin{array}{llll}\text { C } & 6.145771297 & 7.457601816 & 7.611036098\end{array}$

$\begin{array}{llll}\text { C } & 6.692277336 & 6.925086183 & 6.436978410\end{array}$

H $\quad 6.296266990 \quad 7.232777526 \quad 5.469911362$

C $\quad 5.288215194 \quad 3.698995653 \quad 5.818592932$

$\begin{array}{llll}\mathrm{H} & 4.252903002 & 3.332052834 & 5.881266568\end{array}$

$\begin{array}{llll}\text { H } & 5.384434851 & 4.569987793 & 6.478875528\end{array}$

$\begin{array}{lllll}\mathrm{H} & 5.940405467 & 2.903701217 & 6.210571700\end{array}$

$\begin{array}{llll}\text { C } & 4.641324754 & 5.524176676 & 3.404257428\end{array}$

H $4.884139199 \quad 5.790598373 \quad 2.367015791$

$\begin{array}{llll}\text { H } & 4.757534339 & 6.423024599 & 4.024446275\end{array}$

H $3.580419933 \quad 5.234481211 \quad 3.431862146$

C $\quad 5.486844743 \quad 2.568864965 \quad 2.979955985$

H $\quad 5.618197191 \quad 2.766009086 \quad 1.908973080$

$\begin{array}{llll}\mathrm{H} & 4.473419361 & 2.167632790 & 3.132184595\end{array}$

H $\quad 6.196866751 \quad 1.778104485 \quad 3.265386193$

C $\quad 12.093696303 \quad 4.662348560 \quad 6.681890507$

$\begin{array}{llll}\mathrm{H} & 12.423933159 & 3.791657204 & 6.096114603\end{array}$

$\begin{array}{llll}\text { H } & 11.351408033 & 4.318607250 & 7.417042553\end{array}$

$\begin{array}{llll}\mathrm{H} & 12.966056047 & 5.030512892 & 7.241538527\end{array}$

$\begin{array}{llll}\text { C } & 12.661374170 & 6.607260613 & 4.323159823\end{array}$

$\begin{array}{llll}\text { H } & 13.200534576 & 5.792552472 & 3.827263591\end{array}$

$\begin{array}{llll}\text { H } & 13.396195424 & 7.235899564 & 4.848871033\end{array}$

$\begin{array}{llll}\text { H } & 12.195146163 & 7.225339718 & 3.542659958\end{array}$

C $\quad \begin{array}{llll}10.838175182 & 7.502446341 & 6.574416218\end{array}$

$\begin{array}{llll}\mathrm{H} & 10.316895705 & 8.230949711 & 5.936543357\end{array}$

$\begin{array}{llll}\mathrm{H} & 11.725819045 & 8.001461552 & 6.991695547\end{array}$

H $\quad 10.166515573 \quad 7.242915484 \quad 7.400752963$

$\begin{array}{lllll}\text { C } & 8.163442052 & 3.915219886 & 1.566650424\end{array}$

$\begin{array}{lllll}\text { C } & 7.252533119 & 4.579864456 & 0.739040774\end{array}$

$\begin{array}{llll}\text { H } & 6.758555878 & 5.477203947 & 1.112424753\end{array}$

C $\quad 7.003964935 \quad 4.123593266 \quad-0.562254824$

C $\quad 6.007791648 \quad 4.876536975 \quad-1.451436047$

$\begin{array}{lllll}\text { C } & 6.437884948 & 6.354797767 & -1.564077211\end{array}$

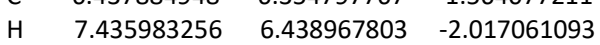

$\begin{array}{llll}H & 6.465966588 & 6.850492665 & -0.583812663\end{array}$

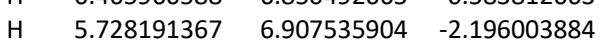

C $\quad 4.607577352 \quad 4.793915840 \quad-0.806266168$

$\begin{array}{llll}\text { H } & 3.871183797 & 5.328504575 & -1.423322121\end{array}$

$\begin{array}{llll}H & 4.596204800 & 5.245521055 & 0.195520864\end{array}$

H $4.280790616 \quad 3.748687012 \quad-0.710101926$

C $\quad 5.930567880 \quad 4.286039999 \quad-2.867212658$

H $\quad 5.218928100 \quad 4.868201351 \quad-3.468439021$

$\begin{array}{llll}H & 5.579968354 & 3.244134525 & -2.859483084\end{array}$

H $\quad 6.904257140 \quad 4.321824986 \quad-3.376793616$

$\begin{array}{llll}\text { C } & 7.684487279 & 2.977183919 & -0.996317555\end{array}$

H $\quad 7.502869706 \quad 2.613282542 \quad-2.003830584$

$\begin{array}{llll}\text { C } & 8.599065902 & 2.287418361 & -0.186029963\end{array}$

C $\quad 9.352869434 \quad 1.038831075 \quad-0.657195746$

$\begin{array}{llll}\text { C } & 8.966605307 & -0.147780214 & 0.252155484\end{array}$

H $\quad 7.886015076 \quad-0.343453466 \quad 0.204685951$ 
Cation C

$\begin{array}{llll}\text { Si } & 5.781779683 & 4.468994140 & 5.426849062\end{array}$

C $\quad 7.437413415 \quad 4.982949468 \quad 4.625629494$

B $\quad 8.889756657 \quad 4.045231714 \quad 4.679175554$

Si $\quad 11.866977183 \quad 5.666806239 \quad 4.515404943$

C $\quad 7.912089190 \quad 4.631437637 \quad 3.306127046$

C $\quad 10.044094112 \quad 4.169548976 \quad 1.996926113$

C $\quad 9.234669652 \quad 2.660322193 \quad 5.264704340$

C $\quad \begin{array}{llll}10.001620879 & 5.324827137 & 4.312748871\end{array}$

H $\quad 10.679461844 \quad 3.499923685 \quad 6.627145855$

$\begin{array}{lllll}\text { C } & 10.231273898 & 2.578873792 & 6.256017885\end{array}$

$\begin{array}{lllll}\text { C } & 10.656157191 & 1.350921228 & 6.762374491\end{array}$

$\begin{array}{lllll}\text { C } & 10.038290323 & 0.190101798 & 6.262411867\end{array}$

H $\quad 10.360363399 \quad-0.775082628 \quad 6.649526297$

$\begin{array}{llll}\text { C } & 9.030529090 & 0.224874591 & 5.295068693\end{array}$

$\begin{array}{llll}\text { C } & 8.641708338 & 1.481104118 & 4.799846331\end{array}$

$\begin{array}{llll}\text { H } & 7.875178028 & 1.540793725 & 4.026822763\end{array}$

$\begin{array}{lllll}\text { C } & 6.222705934 & 4.098294023 & 7.214408984\end{array}$

$\begin{array}{llll}\mathrm{H} & 5.335971656 & 3.743384738 & 7.759653169\end{array}$

$\begin{array}{lllll}H & 6.597388394 & 4.985773297 & 7.745260277\end{array}$

$\begin{array}{llll}\mathrm{H} & 6.990700554 & 3.313093052 & 7.272808744\end{array}$

C $\quad 4.629187850 \quad 5.941878959 \quad 5.300882829$

$\begin{array}{lllll}\mathrm{H} & 4.371707419 & 6.163139093 & 4.256339647\end{array}$

$\begin{array}{llll}\mathrm{H} & 5.074723822 & 6.844727683 & 5.743232688\end{array}$

H $\quad 3.690846866 \quad 5.736604382 \quad 5.836783823$

$\begin{array}{llll}\text { C } & 5.069921118 & 2.943997276 & 4.606437420\end{array}$

H $4.798299691 \quad 3.112881363 \quad 3.557386190$

$\begin{array}{llll}H & 4.162504255 & 2.645503934 & 5.153458010\end{array}$

H $\quad 5.773983411 \quad 2.102539134 \quad 4.653656525$

C $\quad 12.955488025 \quad 4.142176789 \quad 4.451601722$

$\begin{array}{llll}\text { H } & 13.106392551 & 3.809896368 & 3.417352308\end{array}$

H $12.541348322 \quad 3.305247339 \quad 5.028807213$

H $\quad 13.938053084 \quad 4.396298051 \quad 4.877394446$

C $\quad 12.273621314 \quad 6.846098949 \quad 3.117294472$

$\begin{array}{lllll}\text { H } & 12.101203659 & 6.364270360 & 2.144172267\end{array}$

$\begin{array}{llll}\text { H } & 13.330038945 & 7.148416433 & 3.163569038\end{array}$

H $11.659380073 \quad 7.756595397 \quad 3.162870725$

$\begin{array}{lllll}\text { C } & 12.031206368 & 6.491367058 & 6.196809645\end{array}$

H $\quad 11.413322562 \quad 7.398228709 \quad 6.283872216$

$\begin{array}{llll}H & 13.074848526 & 6.799229179 & 6.358176823\end{array}$

$\begin{array}{llll}\text { H } & 11.764170482 & 5.812119332 & 7.019936568\end{array}$

$\begin{array}{llll}\text { C } & 7.051542572 & 4.076466031 & 2.242553511\end{array}$

$\begin{array}{llll}\text { C } & 6.010945768 & 4.901351913 & 1.802119117\end{array}$

H $\quad 5.863971781 \quad 5.867544284 \quad 2.286501293$

C $\quad 5.196861571 \quad 4.514789260 \quad 0.729580890$

$\begin{array}{llll}\text { C } & 4.102408571 & 5.461235306 & 0.224211002\end{array}$

$\begin{array}{llll}\text { C } & 4.771228153 & 6.749391803 & -0.303899597\end{array}$

H $\quad 5.454491265 \quad 6.522210419 \quad-1.134665623$

$\begin{array}{llll}H & 5.348136204 & 7.256953936 & 0.481969258\end{array}$

$\begin{array}{llll}\mathrm{H} & 4.008507436 & 7.451955780 & -0.669454538\end{array}$

$\begin{array}{llll}\text { C } & 3.151166987 & 5.814646253 & 1.386211498\end{array}$

$\begin{array}{llll}\mathrm{H} & 2.349889309 & 6.478730026 & 1.032276497\end{array}$

$\begin{array}{llll}H & 3.677252264 & 6.337131177 & 2.197077285\end{array}$

H $\quad 2.687558678 \quad 4.910652939 \quad 1.806113318$

C $\quad 3.274220704 \quad 4.839753945 \quad-0.910336806$

H $2.500768724 \quad 5.551000532 \quad-1.230770102$

$\begin{array}{llll}H & 2.766435315 & 3.919018956 & -0.588666507\end{array}$

H $\quad 3.892685276 \quad 4.607186348 \quad-1.788950601$

$\begin{array}{llll}\text { C } & 5.445179423 & 3.268450970 & 0.141988200\end{array}$

H $\quad 4.820927615 \quad 2.952146074 \quad-0.688979422$

$\begin{array}{llll}\text { C } & 6.474982174 & 2.415777617 & 0.570247805\end{array}$

C $\quad 6.684749121 \quad 1.034696666 \quad-0.060683550$

$\begin{array}{llll}\text { C } & 6.023688094 & -0.008452533 & 0.867118757\end{array}$

$\begin{array}{lllll}\mathrm{H} & 4.944934117 & 0.180061184 & 0.961944033\end{array}$

$\begin{array}{llll}\mathrm{H} & 6.461428116 & 0.024255917 & 1.873656559\end{array}$

H $\quad 6.163692582 \quad-1.023237558 \quad 0.466686545$

C $\quad 6.046490692 \quad 0.932081097 \quad-1.456431979$

H $\quad 6.428457954 \quad 1.709121423 \quad-2.134380052$ 


\begin{tabular}{|c|c|c|c|}
\hline $\mathrm{H}$ & 4.951365928 & 1.012118558 & -1.420999831 \\
\hline $\mathrm{H}$ & 6.284998290 & -0.046036579 & -1.896357805 \\
\hline C & 8.186138063 & 0.723826847 & -0.198227540 \\
\hline & 8.323807572 & -0.268483209 & -0.649856832 \\
\hline & 8.703225393 & 0.717031851 & 0.769261679 \\
\hline & 8.691565611 & 1.465160666 & -0.831954760 \\
\hline $\mathrm{C}$ & 7.286575676 & 2.843655044 & 1.625650422 \\
\hline & 8.117391988 & 2.229873131 & 1.967216917 \\
\hline C & 9.347934443 & 4.788517483 & 3.144625501 \\
\hline C & 9.816567416 & 4.649434638 & 0.710471889 \\
\hline $\mathrm{H}$ & 9.168936176 & 5.515526043 & 0.572997138 \\
\hline C & 10.376240846 & 3.998452347 & -0.398994061 \\
\hline C & 10.055224719 & 4.517457020 & -1.804359445 \\
\hline C & 10.571099181 & 5.965938800 & -1.938522376 \\
\hline $\mathrm{H}$ & 10.339750118 & 6.360588720 & -2.938379808 \\
\hline $\mathrm{H}$ & 11.660345126 & 384943 & -1.796529507 \\
\hline $\mathrm{H}$ & 10.106148229 & 94322 & -1.198502452 \\
\hline C & 8.522757008 & 53661 & -2.002594147 \\
\hline $\mathrm{H}$ & 8.265152772 & 4.876072519 & -3.001386622 \\
\hline $\mathrm{H}$ & 8.001889417 & 5.113450085 & -1.258736673 \\
\hline $\mathrm{H}$ & 8.130806599 & 21357 & -1.913397622 \\
\hline C & 10.700329187 & 51236 & -2.902641592 \\
\hline $\mathrm{H}$ & 10.434138996 & 90046 & -3.888844703 \\
\hline $\mathrm{H}$ & 10.349719181 & 2.618423803 & -2.866181719 \\
\hline $\mathrm{H}$ & 11.797413706 & 084560 & -2.830277190 \\
\hline C & 11.175506362 & 49636 & -0.163454936 \\
\hline $\mathrm{H}$ & 11.616031943 & 2.357762658 & -1.014545063 \\
\hline C & 11.416239560 & 682387 & 1.126578925 \\
\hline C & 12.299564176 & 1.128829511 & 1.320527432 \\
\hline C & 12.347784417 & 214375 & 2.790173436 \\
\hline $\mathrm{H}$ & 11.346276194 & 0.458991960 & 3.186338982 \\
\hline $\mathrm{H}$ & 12.810551936 & 734049 & 3.437267827 \\
\hline $\mathrm{H}$ & 12.949680399 & & 2.874206946 \\
\hline C & 11.758602387 & 053770 & 0.474463890 \\
\hline $\mathrm{H}$ & 10.753409621 & -0.334627536 & 0.806595120 \\
\hline $\mathrm{H}$ & 12.419529713 & -0.914757549 & 0.576127470 \\
\hline $\mathrm{H}$ & 11.702209921 & 0.211936791 & -0.592386823 \\
\hline C & 13.732332749 & 1.475219379 & 0.860271768 \\
\hline $\mathrm{H}$ & 14.394185835 & 0.606736354 & 0.990341033 \\
\hline $\mathrm{H}$ & 14.142891705 & 2.309539756 & 1.447328740 \\
\hline $\mathrm{H}$ & 13.756388168 & 1.763928145 & -0.199458516 \\
\hline C & 10.833762259 & & 2.206624176 \\
\hline $\mathrm{H}$ & 10.949298610 & 2.647148668 & 3.217119162 \\
\hline C & 11.772458915 & 1.229721359 & 7.803954760 \\
\hline C & 8.375648965 & -1.047931000 & 4.745275595 \\
\hline C & 8.774098815 & -2.300605262 & 5.540245895 \\
\hline $\mathrm{H}$ & 9.852997772 & 39339 & 5.477645509 \\
\hline $\mathrm{H}$ & 8.496997828 & 06114 & 6.600760710 \\
\hline $\mathrm{H}$ & 8.254420425 & 25209 & 5.128722482 \\
\hline C & 6.840326781 & -0.907532363 & 4.801266207 \\
\hline $\mathrm{H}$ & 6.498191112 & -0.746675053 & 5.833450891 \\
\hline $\mathrm{H}$ & 6.478945063 & -0.069616230 & 4.189551034 \\
\hline $\mathrm{H}$ & 6.363123191 & -1.821346271 & 4.419759004 \\
\hline C & 8.825562031 & -1.232189097 & 3.280670857 \\
\hline $\mathrm{H}$ & 8.584463035 & -0.348226842 & 2.675074484 \\
\hline $\mathrm{H}$ & 9.910755983 & -1.395304430 & 3.222748345 \\
\hline $\mathrm{H}$ & 8.323168529 & -2.099269843 & 2.827897415 \\
\hline C & 11.252555689 & 0.449865283 & 9.030062135 \\
\hline $\mathrm{H}$ & 12.048895842 & 0.352788318 & 9.781817815 \\
\hline $\mathrm{H}$ & 10.403194796 & 0.970670384 & 9.494761673 \\
\hline $\mathrm{H}$ & 10.922788357 & -0.562404981 & 8.760860555 \\
\hline C & 12.955290125 & 0.467208608 & 7.167297130 \\
\hline $\mathrm{H}$ & 13.343701522 & 1.006680068 & 6.291116516 \\
\hline $\mathrm{H}$ & 13.773290977 & 0.358030747 & 7.893936581 \\
\hline $\mathrm{H}$ & 12.657818343 & -0.537966996 & 6.839190537 \\
\hline C & 12.274853126 & 2.601829126 & 8.279174740 \\
\hline $\mathrm{H}$ & 13.061583154 & 2.464470766 & 9.033414847 \\
\hline $\mathrm{H}$ & 12.709368005 & 3.187969291 & 7.456100206 \\
\hline $\mathrm{H}$ & 11.470479148 & 3.192117436 & 8.742472836 \\
\hline Si & 8.720705657 & 6.022152909 & 5.431729163 \\
\hline & 8.918009990 & 5.958629358 & 6.903765501 \\
\hline
\end{tabular}

\section{Cation D}

$\begin{array}{lccc}\mathrm{Si} & 5.699770864 & 4.272544792 & 3.753415051 \\ \mathrm{C} & 7.546041061 & 4.703152965 & 3.909464668 \\ \mathrm{~B} & 8.334324979 & 5.455837245 & 5.063795615 \\ \mathrm{Si} & 11.378273511 & 6.053741005 & 5.453003538 \\ \mathrm{C} & 8.485613274 & 4.632593826 & 2.750158678 \\ \mathrm{C} & 10.957779975 & 4.706270185 & 2.278842782\end{array}$

$\begin{array}{llll}\text { C } & 7.780951036 & 5.907863306 & 6.440171016\end{array}$

$\begin{array}{lllll}\text { C } & 9.847778713 & 5.306566608 & 4.599832121\end{array}$

$\begin{array}{lllll}\text { H } & 9.345713558 & 5.029447784 & 7.629994014\end{array}$

$\begin{array}{llll}\text { C } & 8.422468673 & 5.606918299 & 7.655578335\end{array}$

$\begin{array}{llll}\text { C } & 7.902200928 & 6.017104775 & 8.886011681\end{array}$

$\begin{array}{llll}\text { C } & 6.712105130 & 6.759936263 & 8.873602423\end{array}$

$\begin{array}{llll}\text { H } & 6.293238208 & 7.090946071 & 9.825082229\end{array}$

$\begin{array}{llll}\text { C } & 6.040416357 & 7.099680089 & 7.691489330\end{array}$

$\begin{array}{llll}\text { C } & 6.592849242 & 6.658136774 & 6.483591522\end{array}$

$\begin{array}{llll}\text { H } & 6.097969049 & 6.903063427 & 5.545092783\end{array}$

$\begin{array}{llll}\text { C } & 4.936784910 & 3.869092099 & 5.429504882\end{array}$

$\begin{array}{llll}\text { H } & 3.842223523 & 3.922735042 & 5.324904356\end{array}$

$\begin{array}{lllll}H & 5.227012476 & 4.565783630 & 6.225845857\end{array}$

$\begin{array}{llll}\text { H } & 5.168925802 & 2.843525781 & 5.746033663\end{array}$

$\begin{array}{lllll}\text { C } & 4.820456845 & 5.773795397 & 3.041029297\end{array}$

$\begin{array}{llll}\text { H } & 5.210830751 & 6.049102357 & 2.053398735\end{array}$

$\begin{array}{llll}H & 4.914166844 & 6.651018056 & 3.695887542\end{array}$

$\begin{array}{llll}\text { H } & 3.747875465 & 5.557856325 & 2.925368114\end{array}$

$\begin{array}{llll}\text { C } & 5.453902874 & 2.759492210 & 2.661979482\end{array}$

$\begin{array}{llll}\text { H } & 5.676257576 & 2.956392349 & 1.606333803\end{array}$

$\begin{array}{llll}\mathrm{H} & 4.408707839 & 2.422693573 & 2.736746333\end{array}$

$\begin{array}{llll}\text { H } & 6.094624107 & 1.924146104 & 2.983526150\end{array}$

$\begin{array}{lllll}\text { C } & 12.165184047 & 4.756893467 & 6.575401382\end{array}$

$\begin{array}{llll}\text { H } & 12.509614875 & 3.884079201 & 6.000133007\end{array}$

$\begin{array}{llll}\text { H } & 11.463475564 & 4.409258119 & 7.346788216\end{array}$

$\begin{array}{llll}\text { H } & 13.042291775 & 5.171377486 & 7.093505676\end{array}$

$\begin{array}{llll}\text { C } & 12.629649406 & 6.666233096 & 4.192651587\end{array}$

$\begin{array}{llll}\text { H } & 13.188580609 & 5.862749235 & 3.700341735\end{array}$

$\begin{array}{llll}\mathrm{H} & 13.347969546 & 7.318697548 & 4.712209705\end{array}$

$\begin{array}{llll}\text { H } & 12.145394168 & 7.263614124 & 3.407088520\end{array}$

$\begin{array}{lllll}\text { C } & 10.841580700 & 7.553856247 & 6.448293376\end{array}$

$\begin{array}{llll}\mathrm{H} & 10.315286616 & 8.271922821 & 5.802202071\end{array}$

$\begin{array}{lllll}H & 11.735381480 & 8.057984596 & 6.845733520\end{array}$

$\begin{array}{llll}\text { H } & 10.177438231 & 7.316321784 & 7.286833638\end{array}$

$\begin{array}{llll}\text { C } & 8.181145364 & 4.069225154 & 1.415150366\end{array}$

$\begin{array}{llll}\text { C } & 7.359541096 & 4.778341964 & 0.533871930\end{array}$

$\begin{array}{llll}\mathrm{H} & 6.933503636 & 5.726114600 & 0.862096552\end{array}$

C $7.111042764 \quad 4.304971801 \quad-0.761421553$

$\begin{array}{llll}\text { C } & 6.194776386 & 5.101847569 & -1.697785056\end{array}$

$\begin{array}{lllll}\text { C } & 6.694229328 & 6.558667958 & -1.798632472\end{array}$

$\begin{array}{llll}\text { H } & 7.714343908 & 6.595695660 & -2.206502264\end{array}$

$\begin{array}{llll}H & 6.700242913 & 7.060841258 & -0.821554610\end{array}$

$\begin{array}{llll}\mathrm{H} & 6.038549930 & 7.137106243 & -2.465199648\end{array}$

$\begin{array}{lllll}\text { C } & 4.764923059 & 5.086993167 & -1.114940492\end{array}$

$\begin{array}{llll}\text { H } & 4.081196333 & 5.653752485 & -1.763645563\end{array}$

$\begin{array}{llll}\mathrm{H} & 4.733057678 & 5.539389067 & -0.114071399\end{array}$

H $4.386879613 \quad 4.057845740 \quad-1.032753203$

$\begin{array}{lllll}\text { C } & 6.153043768 & 4.508906698 & -3.114254299\end{array}$

$\begin{array}{llll}\text { H } & 5.505291496 & 5.126527822 & -3.751579268\end{array}$

$\begin{array}{llll}H & 5.744616533 & 3.488293189 & -3.120998410\end{array}$

$\begin{array}{llll}\mathrm{H} & 7.151574702 & 4.486567488 & -3.574223569\end{array}$

$\begin{array}{llll}\text { C } & 7.713690712 & 3.098981018 & -1.147647335\end{array}$

$\begin{array}{llll}\text { H } & 7.537752282 & 2.724066523 & -2.152168915\end{array}$

$\begin{array}{llll}\text { C } & 8.554145301 & 2.372756842 & -0.292558358\end{array}$

C $\quad 9.253846948 \quad 1.075307364 \quad-0.713230512$

$\begin{array}{llll}\text { C } & 8.796957157 & -0.066085261 & 0.220650236\end{array}$

H $\quad 7.709237568 \quad-0.212258711 \quad 0.157318015$

$\begin{array}{llll}H & 9.050240892 & 0.147443225 & 1.268949036\end{array}$

$\begin{array}{llll}\mathrm{H} & 9.288543277 & -1.009044468 & -0.060104563\end{array}$

$\begin{array}{llll}\text { C } & 8.932951942 & 0.682082380 & -2.162173962\end{array}$

$\begin{array}{llll}\mathrm{H} & 9.256233478 & 1.454682143 & -2.874567103\end{array}$

$\begin{array}{llll}H & 7.857965059 & 0.504279136 & -2.309123371\end{array}$

$\begin{array}{llll}\text { H } & 9.461102631 & -0.246938263 & -2.418077960\end{array}$

$\begin{array}{llll}\text { C } & 10.780906983 & 1.262718872 & -0.580827072\end{array}$

$\begin{array}{llll}\text { H } & 11.302397361 & 0.332007924 & -0.848701092\end{array}$ 


$\begin{array}{cccc}\text { H } & 9.693648018 & 0.684557744 & 5.973797871 \\ \text { H } & 10.889830269 & 1.995034849 & 5.791546698 \\ \mathrm{C} & 10.496334120 & 1.466169556 & 7.850626923 \\ \mathrm{H} & 10.821231916 & 2.424056601 & 8.274925075 \\ \mathrm{H} & 9.709488263 & 1.037177203 & 8.483739158 \\ \mathrm{H} & 11.351801798 & 0.776616377 & 7.877607078 \\ \mathrm{C} & 7.066220376 & 1.159872120 & 6.696826115 \\ \mathrm{H} & 6.117391122 & 1.122387416 & 7.250191173 \\ \mathrm{H} & 6.832157385 & 1.092467142 & 5.625241818 \\ \mathrm{H} & 7.649714931 & 0.277630140 & 6.991094355\end{array}$

\section{Cation E}

Si $\quad 5.651651988 \quad 4.374595766 \quad 3.89457$

C $\quad 7.534493186 \quad 4.633996504 \quad 3.858927013$

$\begin{array}{llll}\text { B } & 8.310962791 & 5.506591331 & 4.934744101\end{array}$

$\begin{array}{llll}\text { Si } & 11.315706941 & 6.018506148 & 5.452033525\end{array}$

$\begin{array}{lllll}\text { C } & 8.517831378 & 4.348156388 & 2.761065680\end{array}$

$\begin{array}{llll}\text { C } & 11.020096608 & 4.485234484 & 2.348334296\end{array}$

$\begin{array}{llll}\text { C } & 7.758358476 & 6.019403012 & 6.293416503\end{array}$

C $\quad 9.810922218 \quad 5.248013996 \quad 4.583553596$

$\begin{array}{llll}\text { H } & 8.984683375 & 4.697932253 & 7.476262859\end{array}$

$\begin{array}{llll}\text { C } & 8.209559148 & 5.464144665 & 7.503207231\end{array}$

C $7.697708454 \quad 5.869728475 \quad 8.739515137$

$\begin{array}{lllll}\text { C } & 6.719904657 & 6.873883258 & 8.737598372\end{array}$

$\begin{array}{llll}\text { H } & 6.310997098 & 7.207144890 & 9.692665080\end{array}$

$\begin{array}{lllll}\text { C } & 6.252260589 & 7.476350281 & 7.560435484\end{array}$

$\begin{array}{llll}\text { C } & 6.783085485 & 7.028341528 & 6.345331116\end{array}$

$\begin{array}{llll}\mathrm{H} & 6.442334371 & 7.475654776 & 5.412756784\end{array}$

C $5.144845399 \quad 4.026622859 \quad 5.671302300$

$\begin{array}{llll}\text { H } & 4.081540364 & 3.744528128 & 5.699514610\end{array}$

$\begin{array}{llll}H & 5.292414547 & 4.889799186 & 6.330975837\end{array}$

$\begin{array}{llll}\text { H } & 5.719098157 & 3.187443749 & 6.093477081\end{array}$

$\begin{array}{llll}\text { C } & 4.844573235 & 5.950230395 & 3.259797042\end{array}$

$\begin{array}{llll}\text { H } & 5.080436391 & 6.148287945 & 2.204744950\end{array}$

$\begin{array}{llll}H & 5.162704844 & 6.824486380 & 3.842156435\end{array}$

$\begin{array}{llll}H & 3.750399193 & 5.870670069 & 3.342747055\end{array}$

$\begin{array}{llll}\text { C } & 5.017798127 & 2.918902282 & 2.865616210\end{array}$

$\begin{array}{llll}\text { H } & 5.493694623 & 2.812798527 & 1.882801808\end{array}$

$\begin{array}{llll}H & 3.943254076 & 3.081838414 & 2.689413469\end{array}$

$\begin{array}{llll}H & 5.099567035 & 1.967202857 & 3.409777806\end{array}$

$\begin{array}{llll}\text { C } & 12.214693194 & 4.717032821 & 6.481770335\end{array}$

$\begin{array}{llll}\text { H } & 12.685743665 & 3.944444359 & 5.856593255\end{array}$

$\begin{array}{llll}\mathrm{H} & 11.532261270 & 4.222546491 & 7.189674974\end{array}$

$\begin{array}{llll}\text { H } & 13.016264044 & 5.184176239 & 7.072978367\end{array}$

$\begin{array}{llll}\text { C } & 12.470591120 & 6.769804854 & 4.170740447\end{array}$

$\begin{array}{llll}\text { H } & 13.022855914 & 6.024806606 & 3.586581092\end{array}$

$\begin{array}{llll}H & 13.200809076 & 7.410726031 & 4.687505878\end{array}$

$\begin{array}{llll}\text { H } & 11.914191636 & 7.403807672 & 3.465225494\end{array}$

$\begin{array}{llll}\text { C } & 10.745245427 & 7.411523946 & 6.573089172\end{array}$

$\begin{array}{llll}\mathrm{H} & 10.089628824 & 8.110880707 & 6.035314258\end{array}$

$\begin{array}{llll}\text { H } & 11.629671738 & 7.971404943 & 6.913521553\end{array}$

$\begin{array}{llll}H & 10.197352401 & 7.061407210 & 7.455562472\end{array}$

$\begin{array}{llll}\text { C } & 8.225626611 & 3.745248793 & 1.450666392\end{array}$

$\begin{array}{llll}\text { C } & 7.206825641 & 4.296366627 & 0.664179664\end{array}$

$\begin{array}{llll}\text { H } & 6.618070823 & 5.117198367 & 1.073023996\end{array}$

$\begin{array}{llll}\text { C } & 6.969605026 & 3.844418824 & -0.640335659\end{array}$

$\begin{array}{llll}\text { C } & 5.870642662 & 4.508743478 & -1.477735624\end{array}$

$\begin{array}{llll}\text { C } & 6.202281383 & 6.008841818 & -1.634617767\end{array}$

$\begin{array}{llll}\text { H } & 7.166667141 & 6.144463545 & -2.144680205\end{array}$

$\begin{array}{llll}H & 6.258544765 & 6.517208367 & -0.661987818\end{array}$

$\begin{array}{llll}\text { H } & 5.425422272 & 6.509154224 & -2.230521540\end{array}$

C $4.516665703 \quad 4.354386531 \quad-0.752808697$

$\begin{array}{llll}\text { H } & 3.717246849 & 4.833294122 & -1.336213365\end{array}$

$\begin{array}{llll}\mathrm{H} & 4.530700396 & 4.822039784 & 0.241251073\end{array}$

$\begin{array}{llll}\text { H } & 4.258263791 & 3.293466285 & -0.624507143\end{array}$

$\begin{array}{lllll}\text { C } & 5.749079990 & 3.888309708 & -2.877246933\end{array}$

$\begin{array}{llll}\text { H } & 4.951741163 & 4.397107677 & -3.436079473\end{array}$

$\begin{array}{llll}H & 5.491325904 & 2.820343616 & -2.830703469\end{array}$

$\begin{array}{llll}H & 6.678751100 & 3.996897890 & -3.454191089\end{array}$

$\begin{array}{llll}\text { C } & 7.769811339 & 2.803464441 & -1.132636664\end{array}$

$\begin{array}{llll}\text { H } & 7.595586328 & 2.442165919 & -2.142493278\end{array}$

$\begin{array}{llll}\text { C } & 8.796155135 & 2.223178495 & -0.371021032\end{array}$ 


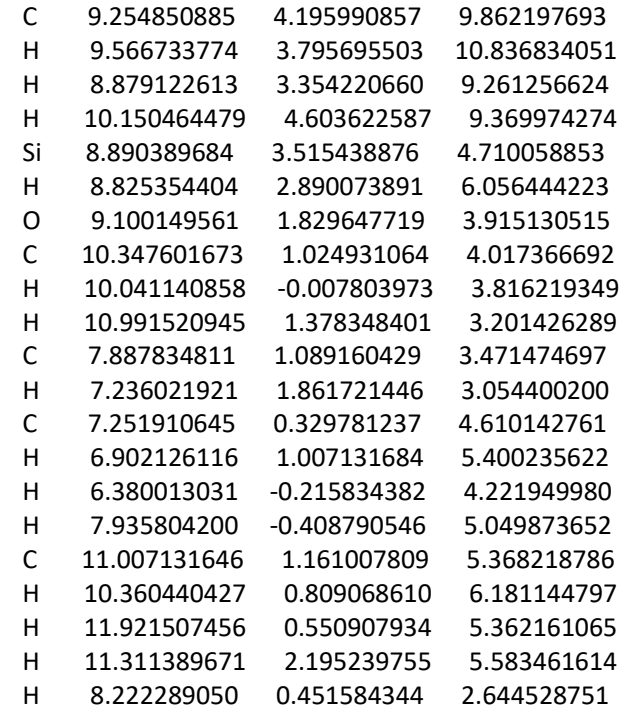

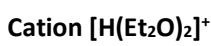

$\begin{array}{lllll}\text { O } & 10.545661928 & 2.643057209 & 10.739480520\end{array}$

$\begin{array}{llll}\text { C } & 12.697766494 & 2.704346949 & 11.886034856\end{array}$

$\begin{array}{llll}\mathrm{H} & 13.674970530 & 2.207179490 & 11.952945413\end{array}$

$\begin{array}{llll}H & 12.212813384 & 2.631491543 & 12.867726397\end{array}$

H $\quad 12.876155716 \quad 3.761053968 \quad 11.648408166$

$\begin{array}{llll}\text { C } & 11.879666997 & 2.015955524 & 10.819642991\end{array}$

H $\quad 11.697386299 \quad 0.959827560 \quad 11.059470660$

$\begin{array}{llll}H & 12.343926645 & 2.079690819 & 9.823309946\end{array}$

$\begin{array}{llll}\text { C } & 9.621867670 & 1.959276503 & 9.822262989\end{array}$

$\begin{array}{llll}H & 10.082809298 & 1.933994062 & 8.822157875\end{array}$

$\begin{array}{llll}H & 9.534578023 & 0.930138498 & 10.195757972\end{array}$

$\begin{array}{llll}\text { C } & 8.289372817 & 2.671611732 & 9.825569558\end{array}$

$\begin{array}{llll}\text { H } & 7.585319277 & 2.110390770 & 9.196798074\end{array}$

$\begin{array}{llll}H & 8.360397402 & 3.684990323 & 9.406960959\end{array}$

$\begin{array}{llll}H & 7.868157636 & 2.724291440 & 10.837924596\end{array}$

$\begin{array}{llll}\text { O } & 10.669081421 & 5.065731649 & 10.584042484\end{array}$

$\begin{array}{llll}\text { H } & 10.586742729 & 3.851168159 & 10.613107386\end{array}$

$\begin{array}{lllll}\text { C } & 11.705588581 & 4.898969359 & 8.387407437\end{array}$

$\begin{array}{llll}\text { H } & 11.779260024 & 5.389334441 & 7.407545765\end{array}$

$\begin{array}{llll}H & 11.399090365 & 3.859400374 & 8.206897528\end{array}$

$\begin{array}{llll}\text { H } & 12.703244122 & 4.910426611 & 8.845263836\end{array}$

$\begin{array}{llll}\text { C } & 10.704502883 & 5.649050180 & 9.234890579\end{array}$

$\begin{array}{llll}H & 10.991674229 & 6.700587250 & 9.369416741\end{array}$

$\begin{array}{llll}H & 9.686812335 & 5.612134923 & 8.815006743\end{array}$

C $\quad 9.728183298 \quad 5.740077335 \quad 11.499907954$

$\begin{array}{llll}\text { H } & 9.997481067 & 6.804455993 & 11.471976932\end{array}$

$\begin{array}{llll}H & 8.712846380 & 5.619133379 & 11.091455929\end{array}$

$\begin{array}{llll}\text { C } & 9.868545050 & 5.158260256 & 12.886345492\end{array}$

$\begin{array}{llll}\text { H } & 9.182907741 & 5.689822453 & 13.560082360\end{array}$

H $\quad 10.888414785 \quad 5.287496880 \quad 13.270233023$

H $\quad 9.604335874 \quad 4.093175365 \quad 12.913392837$

Cation [Cp*Si] ${ }^{+}$

$\begin{array}{llll}\text { Si } & 3.934582464 & 3.861767965 & 1.726273909\end{array}$

$\begin{array}{llll}\text { C } & 2.293652312 & 2.514232664 & 1.329039558\end{array}$

$\begin{array}{llll}\text { C } & 2.351976278 & 2.798408603 & 2.741979833\end{array}$

$\begin{array}{llll}\text { C } & 2.168940594 & 4.218184315 & 2.918952106\end{array}$

$\begin{array}{llll}\text { C } & 1.997196970 & 4.811428563 & 1.615443387\end{array}$

$\begin{array}{llll}\text { C } & 2.074369756 & 3.758369852 & 0.632822179\end{array}$

$\begin{array}{llll}\text { C } & 2.397766835 & 1.162852646 & 0.699681420\end{array}$

$\begin{array}{llll}\mathrm{H} & 1.393071073 & 0.719746807 & 0.622582353\end{array}$

$\begin{array}{llll}H & 3.014894286 & 0.479755948 & 1.294994803\end{array}$

$\begin{array}{llll}H & 2.814638565 & 1.213086611 & -0.313074364\end{array}$

$\begin{array}{llll}\text { C } & 2.527377111 & 1.793059230 & 3.833595721\end{array}$

$\begin{array}{llll}\mathrm{H} & 3.018748839 & 2.224680355 & 4.713477002\end{array}$

$\begin{array}{llll}\text { H } & 3.109748964 & 0.925346515 & 3.502221339\end{array}$

$\begin{array}{llll}\text { H } & 1.539425759 & 1.426872279 & 4.152272931\end{array}$

$\begin{array}{llll}\text { C } & 2.121137162 & 4.941413988 & 4.225765164\end{array}$

H $\quad 1.082570197 \quad 4.965370331 \quad 4.589788179$ 


$\begin{array}{llll}\mathrm{H} & 2.462071597 & 5.979222718 & 4.132737540 \\ \mathrm{H} & 2.727863457 & 4.444541766 & 4.991858498 \\ \mathrm{C} & 1.740474782 & 6.256743960 & 1.335722802 \\ \mathrm{H} & 0.655413820 & 6.441726562 & 1.347414296 \\ \mathrm{H} & 2.115662369 & 6.556613326 & 0.350226640 \\ \mathrm{H} & 2.194191390 & 6.907788201 & 2.092193306 \\ \mathrm{C} & 1.911629975 & 3.921089855 & -0.843713703 \\ \mathrm{H} & 2.466877015 & 3.159535892 & -1.403775531 \\ \mathrm{H} & 2.238515242 & 4.910029969 & -1.185843257 \\ \mathrm{H} & 0.847777190 & 3.814863078 & -1.105707110\end{array}$




\section{Literature}

[1] R. K. Harris, E. D. Becker, S. M. Cabral de Menezes, R. Goodfellow, P. Granger, Pure Appl. Chem. 2001, 73, 1795-1818.

[2] T. Heitkemper, L. Naß, C. P. Sindlinger, Dalton Trans. 2020, 49, 2706 - 2714.

[3] I. Krossing, Chem. Eur. J. 2001, 7, 490-502.

[4] a) L. Hintermann, Beilstein J. Org. Chem. 2007, 3, 22; b) M. Pompeo, R. D. J. Froese, N. Hadei, M. G. Organ Angew. Chem. Int. Ed. 2012, 51, 11354-11357.

[5] R. S. Ghadwal, H. W. Roesky, S. Merkel, J. Henn, D. Stalke, Angew. Chem. Int. Ed. 2009, 48, 5683-5686.

[6] a) P. Jutzi, D. Kanne, C. Krüger, Angew. Chem. Int. Ed. Engl. 1986, 25, 164-164; b) P. Ghana, M. I. Arz, G. Schnakenburg, M. Straßmann, A. C. Filippou, Organometallics 2018, 37, 772-780.

[7] I. Krossing, A. Reisinger, Eur. J. Inorg. Chem. 2005, 2005, 1979-1989.

[8] a) P. Jutzi, A. Mix, B. Rummel, W. W. Schoeller, B. Neumann, H.-G. Stammler, Science 2004, 305, 849-851; b) E. Fritz-Langhals, Org. Process Res. Dev. 2019, 23, 2369-2377.

[9] SAINTV8.30C, 2013, Bruker AXS, Madison, USA.

[10] a) G. M. Sheldrick, SADABS, University of Göttingen, Göttingen, Germany, 2008; b) L. Krause, R. Herbst-Irmer, G. M. Sheldrick, D. Stalke, J. Appl. Crystallogr. 2015, 48, 3-10.

[11] G. M. Sheldrick, Acta Crystallogr. 2015, A71, 3.

[12] G. M. Sheldrick, Acta Crystallogr. 2015, C71, 3.

[13] C. B. Hübschle, G. M. Sheldrick, B. Dittrich, J. Appl. Crystallogr. 2011, 44, 1281-1284.

[14] D. Kratzert, I. Krossing, J. Appl. Crystallogr. 2018, 51, 928-934.

[15] a) F. Neese, Wiley Interdiscip. Rev. Comput. Mol. Sci. 2012, 2, 73-78; b) F. Neese, Wiley Interdiscip. Rev. Comput. Mol. Sci. 2018, 8, e1327.

[16] S. Grimme, S. Ehrlich, L. Goerigk, J. Comput. Chem. 2011, 32, 1456-1465.

[17] a) A. D. Becke, Phys. Rev. A 1988, 38, 3098-3100; b) J. P. Perdew, W. Yue, Phys. Rev. B 1986, 33, 8800-8802; c) A. Schäfer, C. Huber, R. Ahlrichs, J. Chem. Phys. 1994, 100, 5829-5835; d) F. Weigend, R. Ahlrichs, Phys. Chem. Chem. Phys. 2005, 7, 3297-3305; e) K. Eichkorn, F. Weigend, O. Treutler, R. Ahlrichs, Theor. Chem. Acc. 1997, 97, 119-124.

[18] a) E. D. Glendening, C. R. Landis, F. Weinhold, Wiley Interdiscip. Rev. Comput. Mol. Sci. 2012, 2, 1-42; b) E. D. Glendening, J. K. Badenhoop, A. E. Reed, J. E. Carpenter, J. A. Bohmann, C. M. Morales, P. Karafiloglou, C. R. Landis, F. Weinhold, NBO7, Theoretical Chemical Institute, University of Wisconsin Madison, 2018.

[19] a) G. A. Zhurko, ChemCraft, Version 1.7 (build132), 2014; b) G. Knizia, J. E. M. N. Klein, Angew. Chem. Int. Ed. 2015, 54, 5518-5522; c) G. Knizia, iboView, 2015.

[20] D. Andrae, U. Häußermann, M. Dolg, H. Stoll, H. Preuß, Theoretica chimica acta 1990, 77, 123-141.

[21] R. F. W. Bader, Atoms in Molecules A Quantum Theory, Oxford University Press, Oxford, 1990.

[22] T. A. Keith, AIMAll Program Suite, TK Gristmill Software, Overland Parks KS USA, 2019.

[23] T. Lu, F. Chen, J. Comput. Chem. 2012, 33, 580-592.

[24] T. D. Goddard, C. C. Huang, E. C. Meng, E. F. Pettersen, G. S. Couch, J. H. Morris, T. E. Ferrin, Protein Science 2018, 27, 14-25.

[25] J. P. Perdew, K. Burke, M. Ernzerhof, Phys. Rev. Lett. 1996, 77, 3865-3868.

[26] T. Heitkemper, C. P. Sindlinger, Chem. Eur. J. 2020, 26, 11684-11689.

[27] a) Z. Chen, C. S. Wannere, C. Corminboeuf, R. Puchta, P. v. R. Schleyer, Chem. Rev. 2005, 105, 3842-3888; b) A. Stanger, J. Org. Chem. 2006, 71, 883-893. 